\title{
Management Quality and Innovation in Private Firms and the IPO Market Rewards to Innovative Activity
}

\author{
Thomas J. Chemmanur* \\ Manish Gupta** \\ and \\ Karen Simonyan ${ }^{* * *}$
}

Current version: September 2018

* Professor of Finance and Hillenbrand Distinguished Fellow, Carroll School of Management, Boston
College, 440 Fulton Hall, Chestnut Hill, MA 02467, USA. E-mail: chemmanu@bc.edu. Phone: +1-617-
552-3980. Fax: +1-617-552-0431.

** Assistant Professor of Finance, University of Nottingham, C47 Business School South, Jubilee Campus, Nottingham NG8 1BB, UK. Email: manish.gupta@nottingham.ac.uk. Phone: +44-115-951-4781. Fax: $+44-115-846-6667$.

*** Associate Professor of Finance, Sawyer Business School, Suffolk University, 8 Ashburton Place, Boston, MA 02108, USA. E-mail: ksimonya@suffolk.edu. Phone: +1-617-973-5385. Fax: +1-617-3051755 .

For helpful comments and discussions, we thank Sanjay Banerji, Prachi Deuskar, Sonia Falconieri, Gang $\mathrm{Hu}$, Anzhela Knyazeva, Lei Kong, Karthik Krishnan, Haitian Lu, Abraham Ravid, Cong Wang, Xuan Tian, Qianqian $\mathrm{Yu}$ and seminar participants at the Ola Bengtsson Memorial Seminar at Lund University (Best Paper Award), Chinese University of Hong Kong, University of Nottingham, Hong Kong Polytechnic University, and conference participants at the 2015 Financial Management Association Meetings and the 2017 European Finance Association Meetings. We alone are responsible for any errors or omissions. 


\title{
Management Quality and Innovation in Private Firms and the IPO Market Rewards to Innovative Activity
}

\begin{abstract}
Using hand-collected data on top management team human capital ("management quality") of a large sample of private firms, we analyze the effect of top management quality on pre-IPO innovativeness and the innovation strategies of these firms. We also analyze how management quality and pre-IPO innovation relate to these firms' IPO characteristics. We hypothesize that firms with higher quality management teams invest in a greater proportion of long-term (innovative) projects, select better innovation projects, and manage innovation resources more efficiently, resulting in higher innovation productivity. We also hypothesize that such firms reap greater IPO market rewards. The evidence supports these hypotheses.
\end{abstract}

Keywords: Corporate Innovation; Private Firms; Initial Public Offerings (IPOs); Top Management Human Capital

JEL Codes: G31; O31; O32 


\section{Introduction}

The importance of innovation for the long-run success and competitive advantage of firms is well known since Schumpeter and has been discussed extensively in the literature (see, e.g., Porter (1992)). However, the precise drivers of innovation are less well understood. It has been argued that, since innovation is a process involving great uncertainty and high risk of failure (see, e.g., Holmstrom (1989)), the drivers of innovation may differ significantly from those of more routine tasks. Thus, Manso (2011) argues that motivating innovation needs significant tolerance for failure in the short run and reward for success in the long run. One factor that may significantly affect corporate innovation that has been relatively neglected in the literature is the human capital or "quality" of a firm's top management team. ${ }^{1}$ In particular, while it is well known that venture capitalists and other early-stage investors analyze the top management quality of a private firm before investing in that firm, there has been little analysis in the literature on the relationship between the top management human capital of private firms and their capacity to innovate. ${ }^{2}$ The objective of this paper is to use hand-collected dataset on the characteristics of the top management teams of a sample of venture-backed private firms to empirically analyze how the human capital of top management team members affects the innovativeness of private firms in the years before they go public, and how the market for initial public offerings (IPO) of equity rewards greater innovation productivity and higher management quality in private firms when they eventually go public.

We study two related research questions in this paper. First, how does the top management quality of private firms affect their innovation productivity and innovation strategies prior to going public? We make use of the measures of top management human capital ("management quality" from now on, discussed in detail below) and relate them to measures of input to innovation such as $R \& D$ expenses, measures of innovation output such as the number of patents awarded to a firm (quantity of innovation) and the citations per patent (quality of innovation), as well as measures of innovation

\footnotetext{
${ }^{1}$ The importance of the human capital of employees in affecting firm performance has been hypothesized in the seminal theoretical work of Becker (1962), among others.

${ }^{2}$ An exception is the contemporaneous paper by Chemmanur, Kong, Krishnan, and Yu (2018), who use a panel dataset from the BoardEx database to study the relationship between top management quality and innovation in established public firms. We will discuss in more detail how our paper relates to the above paper in the next section.
} 
strategies. Second, how does the IPO market reward greater innovativeness and higher top management quality in private firms in terms of the market valuation of firm equity (both at the IPO and in the immediate post-IPO secondary market), the age at which such firms are able to go public, and their postIPO operating performance?

The quality and reputation of a firm's management team may affect its innovation input and its innovation output in several ways. First, Chemmanur and Jiao (2012) argue that more talented managers have the ability to create long-run value by investing in long-term rather than short-term projects. This implies that higher quality managers will select a greater proportion of long-term projects (i.e., more innovative projects in our setting), so that firms with higher quality management teams may invest larger amounts in innovative projects. Second, higher quality management teams may select projects with greater innovation productivity. Third, higher quality managers may hire higher quality employees (scientists and engineers) who are likely to be more innovative and such managers may be able to manage these employees better (e.g., by exhibiting greater failure tolerance: see Manso (2011)), resulting in greater innovation productivity for their firms. Based on the above, we conjecture that entrepreneurial firms with higher top management quality will be more innovative before their IPOs, as measured by their input into innovative projects as well as by the quantity and quality of their innovation output.

Top management quality may affect the innovation strategies adopted by private firms in potentially opposite ways. On the one hand, since higher quality top management teams may bring greater knowledge resources to the firm, firms with such top management teams may adopt riskier innovation strategies aimed at pushing the knowledge boundaries of the firm outward. On the other hand, since higher quality top management team members are likely to have more valuable reputations to protect, and riskier innovation strategies are associated with a higher chance of failure, firms with higher quality top management teams may adopt more conservative innovation strategies.

The innovativeness and management quality of a private firm may also affect its valuation and age at IPO as well as its post-IPO operating performance. Assuming that many of the innovations developed by private firms before IPO turn out to be positive net present value (NPV) projects, we would 
expect firms with greater innovation output and managed by higher quality top management teams to generate larger long-run cash flows (better post-IPO operating performance) and thus have higher IPO and immediate secondary market valuations. Since going public is costly for a firm, but has the benefit of raising external capital on more advantageous terms compared to private equity financing, a private firm will go public when the benefit of doing so exceeds the cost (see, e.g., Chemmanur and Fulghieri (1999) or Clementi (2002) for theoretical models of the going public decision). This means that firms with greater pre-IPO innovation productivity will go public earlier, since such firms will reach the above tipping point (where the benefit of going public exceeds the cost of doing so) at a younger age. Assuming that a firm with a given innovation productivity will generate larger long-run cash flows if managed by a higher quality top management team, we expect the joint effect of greater pre-IPO innovation productivity and higher management quality to also result in better post-IPO operating performance, higher firm valuation (both at the IPO and in the immediate post-IPO secondary market), and a younger age at IPO.

We test hypotheses based on the above theoretical conjectures using data on a sample of venturebacked private firms going public during 1993-2004. Data on management quality were hand-collected from IPO prospectuses. We make use of individual proxies for management quality used by Chemmanur and Paeglis (2005) and Chemmanur, Paeglis, and Simonyan (2011). We also follow the methodology in these papers and make use of common factor analysis on the individual management quality proxies to generate a management quality factor (MQFactor), which we use in our empirical analysis. ${ }^{3}$ We make use of the number of patents granted to a firm and the number of citations received by each patent obtained from the National Bureau of Economic Research (NBER) Patent Citation database as our main measures of firm innovation. Specifically, patent counts measure the quantity and citations per patent measure the quality of innovation output. The use of patenting to capture firms' innovation output has now become standard in the innovation literature (see, e.g., Seru (2014) or Chemmanur, Loutskina, and Tian (2014)).

\footnotetext{
${ }^{3}$ However, neither of these papers studies the relationship between top management quality and innovation or how the IPO market rewards the innovation productivity of private firms, which is our focus in this paper.
} 
We confine our study to venture-backed entrepreneurial firms for two reasons. First, venturebacked firms typically belong to industries where innovation is an important component of firm value (e.g., software, pharmaceutical, biotechnology). ${ }^{4}$ Second, since the existing literature has shown that venture backing affects firm innovation (see, e.g., Tian and Wang (2014)) and the focus of this study is on the effect of top management quality on innovation (and not on the effect of venture backing), we are able to eliminate the confounding effects of venture backing by confining our study to firms that are similar to each other in terms of venture backing.

We first summarize our empirical findings on the effect of the top management quality of a private firm on its pre-IPO innovation input and pre-IPO innovation output. First, our baseline analysis shows that firms with higher top management quality (as measured by our management quality factor) provide greater input to innovation (as measured by their pre-IPO R\&D expenses). Second, we find that firms with higher top management quality generate greater pre-IPO innovation output as measured by both the quantity (number of patents) and the quality (citations per patent) of innovation.

It may be argued that top management quality is potentially endogenous, since higher quality firms are more likely to attract higher quality top managers. In order to control for this potential endogeneity of top management quality, we conduct an instrumental variable (IV) analysis of the effect of management quality on innovation. The starting point in the construction of our instrument for management quality is a plausibly exogenous shock to the supply of executives who might serve as potential managers. The motivation for this exogenous shock as a potential instrument for management quality comes from the fact that potential top managers hired by private firms often come from established firms and many top managers from established firms choose to move to private firms after their firms become targets of an acquisition. Thus, in order to exploit this plausibly exogenous shock to the supply of executives caused by established firms becoming targets of acquisitions, we use the number of acquisitions conducted in the entrepreneurial firm's industry (within three years prior to the

\footnotetext{
${ }^{4}$ Since most of the firms in our non-venture-backed IPO sub-sample are in industries that are not innovationintensive, we do not find significant variation in patents and citations per patent in this sub-sample.
} 
entrepreneurial firm's IPO) in the state in which the entrepreneurial firm is headquartered as the starting point in the construction of our instrument.

However, the mobility of executives who move from one firm to another may be affected by the enforceability of non-compete clauses in their employment contracts which prohibit them from joining or founding a rival company within a few years after leaving their firm. The enforceability of such noncompete clauses exhibits both cross-state and time series variation leading to variation in the mobility of managers that is unlikely to be related to corporate innovation. Therefore, in order to construct our instrument, we multiply the number of acquisitions as described above by the reciprocal of one plus the enforceability index created by Garmaise (2009). ${ }^{5}$ In other words, the instrument we use is the number of acquisitions in the industry and state of the sample firm within three years prior to its IPO weighted by the reciprocal of one plus the enforceability index of non-compete clauses in that state. Thus, our instrument makes use not only of the strong correlation between industry acquisitions and the movement of top managers but also of the exogenous variation in the ability of managers to move. The results of our IV analysis using this instrument are consistent with those of our baseline analysis discussed earlier, indicating that our findings on the relationship between the top management quality of private firms and their pre-IPO innovation are robust to controlling for the potential endogeneity of management quality.

The results from the second part of our analysis, where we study the relationship between top management quality and private firm innovation strategies as well as the relationship between top management quality and inventor quality are as follows. First, we find support for the notion that private firms with higher top management quality engage in riskier innovation strategies, innovations involving new technologies, and those pushing forward the knowledge boundaries of the firm. Consistent with this, we find that the relationship between top management quality and the fraction of firm patents using new knowledge (explorative patents) is positive and significant (and is stronger than the relationship between top management quality and the fraction of firm patents using existing knowledge (exploitative patents)).

\footnotetext{
${ }^{5}$ This enforceability index is constructed for each U.S. state and ranges from zero to nine. The higher values of this index indicate greater enforceability of non-compete agreements in a given state and thus less mobility of the managers from that state.
} 
Further, top management quality is positively and significantly related to innovation diversity (see, e.g., Brav, Jiang, Ma, and Tian (2018)). Finally, firms with higher top management quality are able to hire a larger number of high quality inventors (those receiving top $10 \%$ of citations across technology classes) in the years before their IPO. These results continue to hold in our IV analysis of innovation strategies and inventor quality using the instrument for top management quality described above.

The results from the third and final part of our analysis, where we study the relationship between pre-IPO innovativeness, top management quality, and the IPO market rewards to innovative activity are as follows. First, firms that are more innovative pre-IPO (as measured by either the quantity or the quality of innovation) receive higher IPO and immediate secondary market valuations. Second, when we divide firms into four quadrants: high and low pre-IPO innovation firms (firms with above and below the median number of patents or citations per patent) and high and low management quality firms (firms with above and below the median top management quality as measured by MQFactor), we find that the joint effect of pre-IPO innovation and management quality on firm valuation at IPO is also positive. In other words, firms in the first quadrant (above-median pre-IPO innovativeness and above-median top management quality) have significantly higher valuations relative to the average for firms in the other three quadrants. Third, firms that are more innovative pre-IPO (as measured by either the quantity or the quality of innovation) are able to go public at a younger age. Fourth, the joint effect of pre-IPO innovation and top management quality on a firm's age at IPO is also negative. Fifth, firms that are more innovative pre-IPO (as measured by either the quantity or the quality of innovation) realize larger increases in post-IPO operating performance in the years after IPO (relative to the pre-IPO year). Sixth, the joint effect of preIPO innovation and top management quality on the above increases in post-IPO operating performance is also positive. Overall, our results in the final part of our paper indicate that firms with greater pre-IPO innovativeness are able to translate this into a higher growth in post-IPO operating cash flows, and that the IPO market, anticipating this, rewards such firms with higher IPO market valuations and enables them to go public earlier. These IPO market rewards to pre-IPO innovativeness are greater for firms managed by higher quality top management teams. 
The rest of this paper is organized as follows. Section 2 discusses how our paper is related to the existing literature. Section 3 summarizes the relevant theory and develops testable hypotheses. Section 4 describes our data. Section 5 discusses our measures of management quality, product market innovation, and innovation strategies. Section 6 presents our empirical tests and results. Section 7 concludes.

\section{Relation to the Existing Literature and Contribution}

Our paper contributes to several strands in the existing literature. The theoretical and empirical literature closest to our paper is the one that analyzes innovation around a firm's going public decision and the effect of patents and innovation on the going public decision of a private firm and its post-IPO performance. Two theoretical models that incorporate the effect of going public on the innovation productivity of a firm are Ferreira, Manso, and Silva (2014) and Spiegel and Tookes (2016). Both models predict that firms will be more innovative pre-IPO rather than post-IPO, though for reasons somewhat different from each other. Bernstein (2015) empirically analyzes how the innovation productivity of firms changes from before an IPO to after, and shows that going public leads to a decline in the innovation productivity of firms. Aggarwal and Hsu (2014) find that innovation quality is highest under private ownership and lowest under public ownership, with acquisition intermediate between the two. Gao, Hsu, and Li (2018) compare the innovation strategies of public and private firms and show that public firms' patents rely more on existing knowledge, are more exploitative (and less likely in new technology classes), while private firms' patents are broader in scope and more exploratory. Acharya and Xu (2017) examine the relationship between innovation and a firm's financial dependence and demonstrate that public firms in external (internal) financing dependent industries have a better (worse) patent portfolio than their private counterparts. Cao, Jiang, and Ritter (2015) analyze the predictive power of patents for the long-run stock return performance of IPOs, and show that venture-backed firms with at least one patent at the time of IPO outperform other venture-backed firms in terms of three-year buy-and-hold market-adjusted stock returns. In comparison with the above literature, ours is the first paper to analyze the relationship between top management quality and innovation in private firms, and how private firm 
innovation and top management quality affect the IPO valuation, age at IPO, and post-IPO operating performance of firms going public.

Our paper is also related to the broader literature on how various firm, industry, and equity market characteristics affect innovation in established (seasoned) firms. In a contemporaneous paper, Chemmanur, Kong, Krishnan, and Yu (2018) use a panel dataset from the BoardEx database to study the effect of top management team human capital on the innovation productivity and innovation strategies of established firms. Unlike the above paper, our focus here is on the relationship between top management quality and innovation in private firms, and on how private firm innovation and top management quality affect IPO valuation, age at IPO, and post-IPO operating performance. It is well known that there are several important differences between private and public firms that may affect their ability to innovate as well as to hire high quality top managers and inventors. On the one hand, private firms do not have access to the financial markets and therefore are severely financially constrained; in contrast, since going public gives them a large cash infusion through the IPO and provides them with repeated access to the stock and bond markets, public firms are less financially constrained. Further, having publicly traded equity may make it easier for public firms to attract high quality top managers (using equity-based compensation schemes). On the other hand, public firms suffer from greater stock market induced pressure to deliver short-term results (corporate myopia) which may affect their incentive to invest in innovative (long-term) projects and the type of innovation projects they undertake. Given the above, our paper makes an important contribution by analyzing, for the first time, the effect of top management quality on innovation productivity and the innovation strategies of private firms by overcoming data availability problems by making use of a large hand-collected dataset on the top management team quality of private firms going public. We make an additional important contribution by showing, again for the first time in the literature, that the stock market rewards private firm innovation at the time of IPO through higher firm valuations.

The theoretical literature on corporate innovation has focused on the optimal organizational form of innovative activity in a setting of incomplete contracting (Aghion and Tirole (1994)) or the nature of contracting between firm managers and inventors (Manso (2011)). There is also a large empirical 
literature focusing on how firm characteristics other than top management quality affect innovation in established firms. Some of these characteristics are: managerial compensation (Lerner and Wulf (2007), Ederer and Manso (2013), Baranchuk, Kieschnick, and Moussawi (2014)); private equity or venture backing (Lerner, Sorensen, and Stromberg (2011), Tian and Wang (2014), Chemmanur, Loutskina, and Tian (2014)); institutional ownership (Aghion, Van Reenen, and Zingales (2013)); CEO overconfidence and CEO characteristics (Hirshleifer, Low, and Teoh (2012), Barker and Mueller (2002)); conglomerate structure (Seru (2014)); and anti-takeover provisions (Atanassov (2013), Chemmanur and Tian (2018), Sapra, Subramanian, and Subramanian (2014)). In a contemporaneous paper, Custodio, Ferreira, and Matos (2017) analyze how the general versus firm-specific human capital of CEOs affects innovation in established firms. In contrast to the last paper above, our paper does not focus on CEO characteristics: rather, we analyze the relationship between top management team quality and innovation in private firms.

Finally, to the extent that we study how the IPO market values pre-IPO innovation and the top management quality of private firms at IPO, our paper is also related to the broader theoretical and empirical literature on IPOs: see Ritter and Welch (2002) for a review. A number of papers in this literature have analyzed how various aspects of private firms affect their IPO and post-IPO characteristics when they go public: e.g., age at IPO (Megginson and Weiss (1991)), post-IPO operating performance (Jain and Kini (1994), Mikkelson, Partch, and Shah (1997)), and heterogeneity in IPO market investor beliefs (Chemmanur and Krishnan (2012)). We contribute to this literature by showing, for the first time, that the innovativeness of a private firm significantly enhances its IPO and immediate after-market valuation as well as its post-IPO operating performance, and enables it to go public at a younger age. ${ }^{6,7}$

\footnotetext{
${ }^{6}$ To the extent that they also study the financial market rewards to innovative activity, a paper indirectly related to ours is Kogan, Papanikolaou, Seru, and Stoffman (2017). They develop a measure of the economic importance of innovations and show that this measure predicts the firm productivity and subsequent output growth. See also Hall, Jaffe, and Trajtenberg (2005) who study how the innovativeness of public firms (measured by their R\&D expenses to asset stock, patents to R\&D expenses, and citations per patent) affects their market value. Pakes (1985) examines the relationship between patents and stock returns in a sample of IPO firms during 1968-1975.

${ }^{7}$ The broader literature on the effect of management quality on financial policies and performance is also indirectly related to our paper: see, e.g., Bertrand and Schoar (2003) who find that manager fixed effects explain some of the heterogeneity in investment, financial, and organizational practices of seasoned firms. The literature on the role of human capital in asset pricing is also indirectly related: see, e.g., Fama and Schwert (1977).
} 


\section{Theory and Hypotheses Development}

We first develop hypotheses on the relationship between the top management quality and pre-IPO innovativeness of a private firm. Next, we develop hypotheses on the effect of top management quality on the pre-IPO innovation strategies pursued by the firm and on the quality of the inventors hired by the firm. Finally, we develop hypotheses on the relationship between private firms' pre-IPO innovation (and top management quality) and their IPO valuation, age at IPO, and post-IPO operating performance.

\subsection{Management Quality, Pre-IPO R\&D Expenses, and Pre-IPO Innovation}

The quality of a firm's top management may affect its innovation input and innovation output in several ways. First, Chemmanur and Jiao (2012) argue that more talented managers have the ability to create long-run value by investing in long-term rather than short-term projects. In their setup, managers (facing asymmetric information in the equity market) have private information about their ability leading to short-run undervaluation of their firm's equity. While investing in long-term projects will create greater long-run value for the firm, investing in such projects leads to the firm's equity undervaluation lasting for a longer time compared to investing in short-term projects whose uncertainty is resolved sooner (see also Stein $(1988,1989)$ for other models of corporate myopia). In this setting, managers with higher reputation (perceived quality) will face smaller equity undervaluation and thus, in equilibrium, will invest in a greater proportion of long-term (innovative) projects. Second, higher quality managers may be able to select projects with greater innovation productivity. Third, higher quality managers may be able to hire higher quality scientists and engineers (who are likely to be more innovative) and manage them better (e.g., by being more failure tolerant: see Manso (2011)), boosting their firms' innovation productivity.

Thus, our first hypothesis is regarding the relationship between top management quality and the input to pre-IPO innovation, as measured by R\&D expenses. Since investment in more innovative (longterm) projects and hiring higher quality scientists and engineers requires more input to innovation, we expect firms with higher management quality to incur greater R\&D expenses pre-IPO (H1). 
Of course, the actual innovation output of a firm may not necessarily be commensurate with the amount of its $R \& D$ expenses. In other words, it is possible that despite significant input to innovation, firms may still languish in their ability to successfully innovate. We therefore next examine whether firms with higher top management quality are more innovative in terms of their innovation output. We expect firms with higher top management quality to have greater innovation output both in terms of the quantity (number of patents) and the quality (number of citations per patent) of innovation (H2).

\subsection{Management Quality, Pre-IPO Innovation Strategies, and Inventor Quality}

We now analyze the possible differences in the innovation strategies adopted by firms with higher versus lower top management quality. On the one hand, higher top management quality firms may pursue more risky innovation strategies, those involving new technologies, and those that are likely to push the knowledge boundaries of the firm outward (H3A). In this case, we would expect firms with higher top management quality to engage in more explorative innovation strategies (in the sense of Brav, Jiang, Ma, and Tian (2018) and Balsmeier, Fleming, and Manso (2017)), venture into the development of newer technologies, or pursue innovation in areas less familiar to them. Further, in this case, we would also expect the patents produced by the firms with higher top management quality to have more non-selfcitations than self-citations, and higher top management quality to be associated with greater innovation diversity. On the other hand, higher top management quality firms may be inclined to engage in less risky (conservative) innovation strategies (H3B). In this case, we would expect firms with higher top management quality to pursue more exploitative innovation strategies (in the sense of Brav, Jiang, Ma, and Tian (2018) and Balsmeier, Fleming, and Manso (2017)), develop more conventional technologies, and pursue innovations in areas that are more familiar to them. Finally, in this case, we would also expect the patents produced by the firms with higher top management quality to have more self-citations than non-self-citations, and higher top management quality to be associated with smaller innovation diversity. ${ }^{8}$

\footnotetext{
${ }^{8}$ It is difficult to predict from a priori theoretical considerations which of the above two scenarios will be realized in practice. We will therefore leave this question to be resolved empirically.
} 
We also analyze how top management quality affects the quality of the scientists and inventors hired by the firm. We hypothesize that firms with higher top management quality are likely to attract and employ higher quality inventors, as measured by inventors' prior track record of citations per patent (H4). ${ }^{9}$

\subsection{Management Quality, Pre-IPO Innovation, and the IPO Market}

We now develop our hypotheses regarding the effect of pre-IPO innovation and top management quality of private firms on their IPO valuation, age at IPO, and post-IPO operating performance.

\subsubsection{Management Quality, Pre-IPO Innovation, and Firm Valuation at IPO}

It is reasonable to believe that a significant fraction of innovations become positive NPV projects in the long run and the NPV of higher quality innovations is likely to be larger. Therefore, if a firm is perceived by IPO market participants as more innovative (measured by the quantity and quality of preIPO innovation), they may conjecture that, ceteris paribus, it will have better future cash flows on average. Since the value of a firm in a symmetric information setting is the present value of its future cash flows, IPO valuation (and immediate after-market valuation) will be greater for firms that are more innovative pre-IPO. Further, the IPO market may view pre-IPO innovation as a signal of future innovation productivity as well (in a setting of information asymmetry between firm insiders and outsiders), enhancing its expectation of better future cash flows, again leading to higher IPO valuation. For these reasons, we expect a positive relationship between pre-IPO innovation and IPO valuation (H5).

Next, if we assume that higher quality managers can implement their firms' innovative projects more ably yielding higher future cash flows, then we would expect that, for a given level of pre-IPO firm innovativeness, firms with higher management quality will have higher IPO (and immediate post-IPO) valuation. Further, as we discussed earlier, firms that are more innovative pre-IPO will have greater IPO valuations (for a given management quality). Given that the individual effects of pre-IPO innovation and

\footnotetext{
${ }^{9}$ One way in which higher quality top managers may attract higher quality inventors is through greater failure tolerance (Manso (2011)).
} 
management quality on IPO firm valuation can each be expected to be positive, we expect their joint effect on IPO valuation to be positive as well (H6).${ }^{10}$ If we divide IPO firms into four quadrants based on management quality (above-median versus below-median management quality) and pre-IPO innovation (above-median versus below-median pre-IPO innovation), hypothesis $\mathbf{H 6}$ has a clear prediction for firms in these four quadrants: high management quality and high pre-IPO innovation (Q1), high management quality and low pre-IPO innovation (Q2), low management quality and high pre-IPO innovation (Q3), and low management quality and low pre-IPO innovation (Q4). The prediction is that firms in quadrant Q1 will have higher IPO valuations than the average IPO valuation of firms in the other three quadrants.

\subsubsection{Management Quality, Pre-IPO Innovation, and Firm Age at IPO}

There are many theoretical models of the going public decision of a firm, two of which have strong predictions for the relationship between pre-IPO innovation and firm age at IPO. The first model is that of Clementi (2002), who develops a dynamic model (in a setting of symmetric information) of the going public decision in which the firm operates in an industry characterized by decreasing returns to scale and where going public is costly. Prior to going public, a borrowing (financial) constraint keeps the firm's scale of production at a sub-optimal level. In this setting, consider a sudden positive productivity shock affecting the firm (resulting in a new set of positive NPV projects becoming available to the firm) which widens the gap between the optimal and the actual scale of the firm. Such a shock means that the marginal benefit of expanding operations by going public outweighs the marginal cost of doing so, resulting in the firm going public at this time. If we assume in the above setting that greater pre-IPO innovation productivity is associated with a larger number of positive NPV projects, then the above reasoning implies that more innovative firms are likely to go public at a younger age (since such firms reach the tipping point where the benefits of going public exceed the cost earlier in their life cycle).

\footnotetext{
${ }^{10}$ Given that Chemmanur, Simonyan, and Tehranian (2016) have shown that there is a positive association between management quality and IPO firm valuation and a negative association between management quality and firm age at IPO, we do not analyze the direct effect of management quality on these two IPO variables here. Rather, our focus here is on how top management quality and pre-IPO innovation jointly affect IPO firm valuation and firm age at IPO.
} 
A second model that considers the effect of asymmetric information on a firm's going public decision is that of Chemmanur and Fulghieri (1999). They model a firm's going public decision in a setting where insiders have private information about firm value, but outside investors in the IPO market can produce information about the firm at a cost. In this setting, outsiders' cost of producing information about the firm declines over time (as firms establish a track record in the product market) and firms go public when this cost falls below a certain threshold value. Thus, assuming that firms with greater preIPO innovativeness are associated with lower costs of information production for outsiders (at any given age), such firms can be expected to go public earlier. ${ }^{11}$ Hence the above two models imply that more innovative firms will go public at a younger age, ceteris paribus $(\mathbf{H 7})$.

Next, we examine the joint effect of pre-IPO innovation and management quality on a firm's age at IPO. In the Clementi (2002) setting discussed earlier, let us now add the assumption that a given innovation will have a greater NPV if implemented by a higher quality management team (possibly because a higher quality management team is able to implement the innovation more efficiently). This implies that for a given extent of pre-IPO innovativeness firms with higher management quality will reap greater benefits from expanding operations by going public. This further implies that such firms are more likely to go public at a younger age (since such firms reach the tipping point where the benefit of going public exceeds the cost earlier). Similarly, in the model of Chemmanur and Fulghieri (1999), if we assume that, for a given extent of innovativeness, firms with higher perceived management quality are associated with a lower outsider cost of information production, the implication will be that such firms may be expected to go public earlier. Given that the individual effects of pre-IPO innovation and management quality on firm age at IPO can be expected to be negative, we expect their joint effect on firm age at IPO to be negative as well (H8). This implies that firms in quadrant Q1 (defined earlier) will have a younger age at IPO compared to the average age at IPO of firms in the other three quadrants.

\footnotetext{
${ }^{11}$ Since, in equilibrium, outsiders' information production costs are borne by the firm through a lower IPO share price, the Chemmanur and Fulghieri (1999) model also predicts that firms that are more innovative pre-IPO will obtain higher IPO valuations, since IPO market investors' information production costs will be lower for such firms.
} 


\subsubsection{Management Quality, Pre-IPO Innovation, and Post-IPO Operating Performance}

Given that a significant fraction of innovations are expected to become positive NPV projects in the long run, more innovative firms are likely to have a larger number of positive NPV projects leading to better operating performance as these projects are implemented over time. However, one confounding factor in the relationship between pre-IPO innovation and post-IPO operating performance is a firm's age at IPO. As we discussed earlier, firms that are more innovative may be able to go public at a younger age, at which point their profitability may be lower than that of firms going public at an older age. Thus, if this second effect (firm age at IPO) dominates, pre-IPO innovation will be negatively related to the level of the firm's long-term post-IPO operating performance. One can separate out the effect of pre-IPO innovation alone on operating performance by studying the growth (changes) in operating performance of a firm after IPO: we expect firms with greater pre-IPO innovation to experience unambiguously higher growth rates in operating performance in the years after IPO (H9).

Next, we examine the joint effect of pre-IPO innovation and management quality on a firm's post-IPO operating performance. For the reasons discussed above, we focus only on the changes in postIPO operating performance. As discussed earlier, let us assume that higher quality managers are able to implement their innovative projects more efficiently and generate higher cash flows. In this case we would expect that, for a given level of pre-IPO innovation, firms with higher top management quality will have a higher growth rate in post-IPO operating performance. Given that the individual effects of pre-IPO innovation and top management quality on the growth in post-IPO operating performance may be expected to be positive, we expect their joint effect on the growth in post-IPO operating performance to be positive as well (H10). This implies that firms belonging to quadrant Q1 (as defined earlier) will have higher growth rates in operating performance compared to firms falling in the other three quadrants.

\section{Data and Sample Selection}

The list of U.S. IPOs in 1993-2004 comes from the SDC/Platinum Global New Issues database. We excluded real estate investment trusts, closed-end funds, unit IPOs, spin-offs, equity carve-outs, 
financial firms (with SIC codes between 6000 and 6999), foreign firms, and leveraged buy-outs. We further eliminated nine firms with no management quality information available in their prospectuses. We also double-checked the venture backing status from the VentureXpert database to consistently identify venture-backed IPOs. Thus, our final sample consists of 1,851 venture-backed IPO firms. ${ }^{12}$

Information on various management quality proxies, such as team size, education, prior managerial experience, functional expertise, and tenure of management team members was handcollected from the "Management" section of IPO prospectuses. The data necessary to calculate the CEO dominance variable came from the "Executive Compensation" section of the prospectuses. Information on internal governance mechanisms (such as CEO/Chairman-of-the-board duality, proportion of outside directors, and insider stock ownership) came from the IPO prospectuses as well. IPO prospectuses were obtained from the Thomson Financial database. Accounting data came from Compustat and stock price data came from CRSP. Innovation output data (number of patents and citations per patent) came from the NBER Patent Citation database. The data (provided by Li, Lai, D'Amour, Doolin, Sun, Torvik, Yu, and Fleming (2014)) necessary for constructing innovation strategy measures were obtained from Harvard Dataverse Network.

\section{Measures of Management Quality, Innovation Output, Innovation Strategies, and Firm Quality \\ 5.1. Measures of Management Quality and Reputation}

We follow Chemmanur, Paeglis, and Simonyan (2011) and Chemmanur and Paeglis (2005) in constructing our management quality measures. Management quality is affected by the amount of human and knowledge resources (including education and experience) available to the management team. Our first proxy for management quality, the management team size, measures the amount of human resources available. It is the number of executive officers with a title of a vice president or higher on the team (TSize). The next two proxies measure the education level of managers. Our second proxy of

\footnotetext{
${ }^{12}$ Given the laborious nature of hand-collecting management quality data from IPO prospectuses, our sample period currently covers IPOs conducted during the twelve year period from 1993 to 2004.
} 
management quality is the percentage of management team members with an MBA degree (PMBA) and the third proxy is the percentage of management team members who are Certified Public Accountants (PCPA). The greater the percentages of MBAs and CPAs on the management team, the greater its quality.

We measure prior managerial experience of management team members by using the following two proxies. Our fourth proxy is the percentage of managers who have served as executive officers at other firms prior to joining the IPO firm (PPriorExp) and our fifth proxy is the percentage of managers who were partners at law or accounting firms prior to joining the IPO firm (PLawAcc). Clearly, the greater the percentage of management team members with prior managerial experience (including experience in the areas of law and accounting) the greater the management team quality.

Our sixth proxy of management quality is the percentage of team members with core functional expertise, namely, the percentage of team members holding positions in the areas of operations and production, $\mathrm{R} \& \mathrm{D}$, sales and marketing, and finance (PCore). The greater the percentage of team members with core functional expertise, the greater the management quality.

Our seventh proxy of management quality is CEO dominance (CEODom). While a strong CEO may improve the cohesion of the management team, a dominating and strong-willed CEO may also severely diminish possible contributions from other team members. Thus, while we believe that CEO dominance is an important measure of team quality, we are agnostic about the direction of the expected impact (positive or negative) of this measure of management quality. Our measure of CEO dominance is the ratio of CEO salary and bonus to the average salary and bonus of other team members listed in the executive compensation section of the prospectus in the fiscal year prior to the IPO. Assuming that CEOs have a great influence over their own pay and a nearly total influence over their subordinates' pay, this measure reflects the gap between the CEO's assessment of his own worth to the firm and his assessment of other team members' worth, and thus is a good measure of CEO dominance. ${ }^{13}$

\footnotetext{
${ }^{13}$ Similar measures have also been used in the strategy and organizational behavior literature to study the effect of management team quality on firm performance: see, e.g., D'Aveni (1990) and Hambrick and D'Aveni (1992), who use such measures to study the deterioration of management team quality around bankruptcies.
} 
Our eighth proxy of management quality measures the reputation of management team members in the business community. It is the number of other firms' corporate boards that team members sit on (Board). While the measures discussed above also partially capture management team reputation, this proxy is a better representation of the reputation and visibility of managers in the business community. The greater the value of Board, the greater the quality and reputation of a firm's management team.

Finally, we also measure the degree of uniformity or heterogeneity in the tenures of management team members. Our ninth proxy of management quality is the average tenure of team members (Tenure), defined as the average number of years that team members have been with the firm. ${ }^{14}$ Greater average tenure may indicate shared experiences and cohesion and thus lower costs of interaction between team members. However, longer tenures may also result in complacency and rigidity in team interactions. Thus, we are agnostic about the direction of the expected impact (positive or negative) of this measure of management quality. An ideal management team would have members from different cohorts, which would ensure an inflow of new ideas and perspectives. Further, a higher management quality would be associated with greater dispersion in such tenures. Therefore, we use the heterogeneity in management team tenures (TenHet) as our tenth management quality proxy. It is defined as the coefficient of variation of management team members' tenures.

\subsection{Common Factor Analysis of Management Quality Variables}

Although the individual proxies discussed above are expected to measure management quality, they may each have unique limitations in capturing the underlying unobservable construct. Therefore, we use common factor analysis to construct a single factor for management quality that will capture the variation common to the observable measures of management quality and reputation. ${ }^{15}$ In order to ensure that this single factor captures only the effect of management quality and not that of other variables such

\footnotetext{
${ }^{14}$ In our empirical tests, we have also used the median team tenure instead of the average team tenure. Our results were similar using this alternative measure.

${ }^{15}$ Several papers in the empirical finance and accounting literature make use of factor analysis to isolate the unobservable construct underlying several proxy variables. See, e.g., Gaver and Gaver (1993) and Guay (1999), who make use of factor analysis to study the size of a firm's investment opportunity set.
} 
as firm size, age, or industry characteristics, we use firm-size-, firm-age-, and industry-dummies-adjusted individual management quality proxies to extract the common factor. Thus, our management quality factor score (MQFactor) is constructed using firm-size-, firm-age-, and industry-dummies-adjusted TSize, MBA, PriorExp, Core, LawAcc, CPA, CEODom, and Board. ${ }^{16}$ These variables refer, respectively, to the management team size, the number of management team members with MBA degrees, the number of management team members with prior managerial experience, the number of management team members with core functional expertise, the number of management team members with prior experience as law or accounting partners, the number of management team members who are CPAs, CEO dominance, and the number of other firms' corporate boards that management team members sit on.

We exclude Tenure and TenHet from the construction of the above common factor since these two proxies have negative factor loadings and negative scoring coefficients if included in the common factor analysis. The interpretation of our common management quality factor becomes problematic when some individual management quality proxies have positive scoring coefficients and others have negative scoring coefficients. Therefore, we restrict our common factor analysis to the first eight management quality proxies, since they have positive factor loadings and positive scoring coefficients when included in the common factor analysis. We then use Tenure and TenHet as control variables in our multivariate regressions. $^{17}$

Table 1 presents the results of our common factor analysis. Panel A of Table 1 shows the starting communalities of eight management quality proxies (for MQFactor described above), estimated as the

\footnotetext{
${ }^{16}$ We adjust individual management quality proxies for firm size, firm age, and industry characteristics by regressing those management quality proxies on firm size, firm age, and 2-digit SIC code industry dummies, and take the residuals of such regressions (in other words, the variation in individual management quality proxies not explained by firm size, firm age, or industry characteristics) to be our firm-size-, firm-age-, and industry-dummiesadjusted individual management quality proxies.

${ }^{17}$ Negative factor loadings and negative scoring coefficients of Tenure and TenHet are due to negative correlations that these two proxies have with other management quality variables. For example, the correlation between Tenure (TenHet) and the percentage of management team members with prior managerial experience at other firms (PPriorExp) is $-0.45(-0.12)$ and the correlation between Tenure (TenHet) and the percentage of management team members with MBA degrees (PMBA) is $-0.12(-0.04)$. Indeed, firms that have management teams with longer average tenures are more likely to develop their managers internally, rather than to hire them from outside, and consequently such managers are less likely to have prior managerial experience at other firms. Similarly, managers who have longer average tenures with their firms are more likely to acquire their managerial skills internally, rather than externally at an educational institution.
} 
squared multiple correlations from regressions of each management quality proxy on the remaining management quality proxies used in our common factor analysis. Panel B of Table 1 presents the eigenvalues of the reduced correlation matrices. As suggested by Harman (1976), the number of factors necessary to approximate the original correlations among individual measures is equal to the number of summed eigenvalues necessary to exceed the sum of communalities. The first factor's eigenvalue in our common factor analysis of MQFactor is 1.72 and it is larger than the sum of communalities of 1.55 . This means that MQFactor parsimoniously explains the intercorrelations between individual management quality proxies. Panel $\mathrm{C}$ of Table 1 presents the correlations between MQFactor and the eight management quality proxies and Panel D of Table 1 provides the summary statistics of MQFactor.

\subsection{Measures of Product Market Innovation}

Following the innovation literature, we use patent-based metrics to capture firm innovativeness. We obtain information on entrepreneurial firm's patenting from the NBER Patent Citation database (see Hall, Jaffe, and Trajtenberg (2001) for details). The database provides detailed information on more than three million patents granted by the U.S. Patent and Trademark Office (USPTO) from 1976 to 2006, including patent assignee names, the number of citations received by each patent, and a patent's application and grant year. We use the NBER bridge file to Compustat to match patents to IPO firms. This link allows us to evaluate the innovation activity of IPO firms starting well before they go public.

The NBER patent database is subject to two types of truncation problems. We follow the innovation literature to correct for these truncation problems. First, patents are recorded in the database only after they are granted and the lag between patent applications and patent grants is significant (about two years on average). As we approach the last few years for which there are patent data available in the patent database (e.g., years 2005 and 2006), we observe a smaller number of patent applications that are eventually granted. This is because many patent applications filed during these years were still under

review and had not been granted until 2006. Following Hall, Jaffe, and Trajtenberg (2001, 2005), we correct for the truncation bias in patent counts using the "weight factors" computed from the application- 
grant empirical distribution. The second type of truncation problem is stemming from citation counts. Patents tend to receive citations over a long period of time, so the citation counts of more recent patents are significantly downward biased. Following Hall, Jaffe, and Trajtenberg (2001, 2005), the citation truncation is corrected by estimating the shape of the citation-lag distribution.

The NBER patent database is unlikely to be subject to survivorship bias. An eventually granted patent application is counted and attributed to the applying firm at the time when the patent application is submitted, even if the firm is later acquired or goes bankrupt. ${ }^{18}$ In addition, patent citations attribute to a patent, but not a firm. Hence, a patent assigned to an acquired or bankrupt firm can continue to receive citations for many years even after the firm goes out of existence. We construct two measures for a firm's pre-IPO innovation output. The first measure, LnCount, is the natural logarithm of one plus the annual truncation-adjusted patent count (the number of patent applications filed in that year that are eventually granted) for a firm. We construct this variable for years -1 and -2 prior to a firm's IPO (LnCount -1 and LnCount -2 , respectively), as well as for years -1 and -2 combined (LnCount $-1 \&-2$ ). If the patent count data either for year -1 or year -2 is missing, we construct LnCount $-1 \&-2$ using available data only. A simple count of patents, however, may not distinguish breakthrough innovations from incremental technological discoveries. Therefore, we construct a second measure of pre-IPO innovation output which intends to capture the importance of patents, LnCite, which is the natural logarithm of one plus the number of non-self-citations per patent a firm applies for in a given year and is eventually granted. ${ }^{19} \mathrm{We}$ exclude self-citations when we compute citations per patent, but our results are robust to including selfcitations. We construct this variable for years -1 and -2 prior to a firm's IPO (LnCite -1 and LnCite -2 , respectively), as well as for years -1 and -2 combined (LnCite $-1 \&-2$ ). If the patent citation data either for year -1 or year -2 is missing, we construct LnCite $-1 \&-2$ using available data only.

18 We construct the innovation variables based on the patent application year. As suggested by the innovation literature (e.g., Griliches, Pakes, and Hall (1987)), the application year is more important than the grant year since it is closer to the time of the actual innovation.

${ }^{19}$ Griliches, Pakes, and Hall (1987) show that the distribution of patents' value is extremely skewed, i.e., most of the value is concentrated in a small number of patents. 
It is important to note that using patenting activity to measure corporate innovation is not without limitations. For example, different industries have various innovation propensity and duration. Young firms in some industries might abstain from patenting for competitive reasons. Therefore, fewer patents generated in an industry might not necessarily be reflective of a less innovative industry. However, we believe that an adequate control for heterogeneity across industries and firms should alleviate this concern and lead to reasonable inferences that can be applicable across industries and firms.

\subsection{Measures of Innovation Strategies and Inventor Quality}

We study a private firm's innovation strategies by making use of the following measures. In order to analyze whether firms with higher management quality undertake more risky innovations involving new knowledge or less risky (conservative) innovations involving existing knowledge, we construct two measures for explorative and exploitative patents. Following Brav, Jiang, Ma, and Tian (2018) we construct ExplorRat (ExploitRat) as the ratio of explorative (exploitative) patents over all the patents applied by a firm in the two-year period prior to its IPO. A patent is explorative if at least $80 \%$ of its citations do not refer to existing knowledge, which includes a firm's previous patent portfolio and all the patents that were cited by the firm's patents filed over the two-year period prior to its IPO. On the other hand, a patent is exploitative if at least $80 \%$ of its citations refer to existing knowledge. Firms innovating in new and untested areas are likely to produce explorative patents, whereas firms innovating in the areas of existing knowledge and technologies are likely to produce exploitative patents.

Our next two measures of innovation strategies count the number of times a firm's patents cite other patents owned by the firm itself and the number of times a firm's patents cite patents owned by other firms (see, e.g., Sorensen and Stuart (2000), Faleye, Hoitash, and Hoitash (2011)). LnNSelfCite is the natural logarithm of one plus the number of non-self-citations (i.e., the number of times that a firm's patent portfolio cites patents owned by other firms) of all the patents cited by a firm in the two-year period prior to its IPO. LnSelfCite is the natural logarithm of one plus the number of self-citations (i.e., the number of times that a firm's patent portfolio cites other patents owned by the firm itself) of all the 
patents cited by a firm in the two-year period prior to its IPO. Firms pursuing innovations in new and unfamiliar areas are likely to have more non-self-citations, while firms pursuing innovations in established areas are likely to have more self-citations.

The fifth measure we use to study innovation strategies is the innovative diversity of a firm's patent portfolio (Diversity), which is equal to one minus the Herfindahl index of the number of patents filed by a firm across the three-digit technology classes in the two-year period prior to its IPO. Firms producing innovations in new (existing) areas are likely to have greater (smaller) innovative diversity.

Finally, we measure the quality of inventors innovating for private firms (InventorQual) as the natural logarithm of one plus the number of inventors whose patents were filed by a firm in the two-year period prior to its IPO and who receive top $10 \%$ of the citations across various technology classes.

\subsection{Measures of Firm Quality and Governance}

In order to separate the effect of top management quality from that of other aspects of firm quality and internal governance, we control for these other aspects by including the following variables as controls in our multivariate tests. The first proxy of firm quality we use is firm size, defined as the natural logarithm of the book value of firm's assets immediately prior to IPO (LnAssets). The second proxy of firm quality is firm age, defined as the natural logarithm of one plus the firm's age (LnAge) ${ }^{20}$ The larger and older the firm, the greater its quality. Further, we control for the proportion of outside directors (directors who are not executive officers, founders, former employees, or anyone engaged in business dealings with the firm) in the firm's board of directors (OutDir). Outside directors can enhance firm quality by providing linkages to external parties (underwriters, financial institutions, and auditors) and by providing additional knowledge and expertise (inputs and perspectives) to the firm's management. ${ }^{21}$ The greater the proportion of outside directors, the greater the firm's quality. We also control for insider stock ownership defined as the proportion of voting power held by firm insiders such as executive officers and

\footnotetext{
${ }^{20}$ These measures of firm quality have been widely used in the literature (Ritter (1984), Michaely and Shaw (1994)).

${ }^{21}$ Several studies in the corporate control literature demonstrated that outside directors enhance firm value (see, e.g., Cotter, Shivdasani, and Zenner (1997) and Borokhovich, Parrino, and Trapani (1996)).
} 
directors prior to IPO (InsideOwn). Next, we control for CEO/Chairman-of-the-board duality by creating a dummy variable equal to one if a firm's CEO is also its Chairman of the board of directors, and zero otherwise (CEO/Chair). Separation of the roles of CEO and the Chairman of the board of directors creates greater accountability and enhances internal governance and management quality. ${ }^{22}$ Finally, we also control for the level of capital expenditures normalized by assets prior to IPO (CapEx/Assets -1) as well as firm profitability prior to IPO measured as net income over sales (NI/Sales -1).

\subsection{Summary Statistics}

Table 2 summarizes our measures of pre-IPO innovation, management quality, and other control variables that we use in our regressions. First we discuss our measures of pre-IPO innovation output (the number of patents and the number of citations per patent). Since the distributions of patent counts and citations per patent are highly right-skewed, we use the natural logarithms of one plus the number of patents and one plus the number of citations per patent in our empirical analysis and report the summary statistics of these variables in Table 2. However, for the discussion below we use the actual number of patents and citations per patent. Both the quantity and the quality of pre-IPO innovation output (defined in section 5.3) in pre-IPO year -1 is greater than that in pre-IPO year -2: the mean number of patents applied for in year -1 (and eventually granted) is 0.68 and it is 0.10 in year -2 , and the mean number of citations per patent applied for in year -1 (and eventually granted) is 3.14 and it is 0.19 in year -2 .

Next we discuss our measures of pre-IPO input to innovation. We use two variables: the ratio of $R \& D$ expenses over assets ( $R \& D / A s s e t s)$ and the natural logarithm of one plus the total $R \& D$ expenses in dollars (LnR\&D). Similar to our pre-IPO innovation output variables, we construct these variables for years -1 and -2 prior to IPO (R\&D/Assets $-1, R \& D /$ Assets -2 , LnR\&D -1, and LnR\&D -2, respectively), and as average $\mathrm{R} \& \mathrm{D} /$ Assets over years -1 and -2 prior to IPO (AveR\&D/Assets $-1 \&-2)$ and the natural logarithm of average R\&D expenses over years -1 and -2 prior to IPO (LnAveR\&D -1 \& -2). Table 2

\footnotetext{
${ }^{22}$ Yermack (1997) shows that firms which separate the roles of a CEO and a Chairman of the board receive higher valuations. Rechner and Dalton (1991) show that such firms outperform those that combine these roles.
} 
shows that the mean of average $\mathrm{R} \& \mathrm{D} /$ Assets over the two-year period prior to IPO is 0.27 and the mean of the natural logarithm of average $R \& D$ expenses over the same two-year period is 10.06 (the mean of average R\&D expenses over the two-year period prior to IPO is $\$ 4.08$ million). Table 2 further shows that firms spend more on R\&D (in absolute dollar terms) in year -1 prior to IPO compared to year -2 prior to IPO, however when normalized by assets $\mathrm{R} \& \mathrm{D} /$ Assets in year -1 is somewhat smaller than that in year -2 .

Table 2 also demonstrates that the pre-IPO innovation produced by the firms in our sample is more explorative rather than exploitative in its nature. The mean value for ExplorRat is 0.29 compared to the mean value of ExploitRat of 0.01. Further, the patents produced by our sample firms in the two-year period prior to IPO cite patents of other firms (LnNSelfCite) more than the patents produced by their own firms (LnSelfCite). On average the patents produced by our sample firms in the two-year period prior to IPO cite 51 patents of other firms and only 0.46 patents of their own firms. Finally, with respect to inventor quality, Table 2 shows that in the two-year period prior its IPO a firm employs on average 2.78 (high quality) inventors whose innovations were patented by the firm in that two-year period and who receive top $10 \%$ of the citations across various technology classes.

Next, Table 2 summarizes our management quality variables. The mean (median) management quality factor score (MQFactor) of sample firms is $0(-0.06)$, with a minimum value of -2.46 and a maximum value of 4.51. The mean (median) size of a firm's management team (TSize) is 6.78 (6), with the smallest management team consisting of one member and the largest of 19 members. On average, $15.6 \%$ of management team members have an MBA degree (PMBA), 55.4\% have held a top management position at another firm prior to joining the IPO firm (PPriorExp), 59.2\% are employed in core functional areas of their firms (PCore), $2.4 \%$ have been partners in law or accounting firms (PLawAcc), and 6.6\% have a CPA certification (PCPA). On average CEOs earn 29.3\% more than the average member of the management team (CEODom). The average number of management team members who sit on other firms' boards is 0.53 (Board). The average tenure of management team members (Tenure) ranges from one to 30 years, with the mean (median) of 4.43 (3.29) years. Finally, the mean (median) tenure heterogeneity (TenHet) of management teams is $0.689(0.573)$. 
The last set of variables presented in Table 2 are our control variables. In the IPO literature, two often-used control variables are firm size and firm age. The median (mean) firm size in our sample is $\$ 24.7$ (\$125) million and the median (mean) age is $7(11.3)$ years. On average, $69.7 \%$ of the directors are outsiders (OutDir). The mean percentage of voting power owned by firm officers and directors prior to IPO (InsideOwn) is $57.2 \%$. CEOs act as board chairmen (CEO/Chair) in 55.8\% of the firms. Finally, the median CapEx/Assets and NI/Sales in year -1 prior to IPO are 0.059 and -0.092 , respectively.

\section{Empirical Tests and Results}

\subsection{The Effect of Management Quality on Pre-IPO Innovation}

\subsubsection{OLS Analysis of the Relationship between Management Quality and Pre-IPO Innovation Input}

In this section, we test hypothesis $\mathbf{H 1}$ in a multivariate regression setting. It predicts that firms with higher management quality will spend more on $R \& D$. Our regression specification is as follows:

$$
\begin{aligned}
& \text { Dependent variable }_{i}=\beta_{0}+\beta_{1} \text { MQFactor }_{i}+\beta_{2} \text { Tenure }_{i}+\beta_{3} \text { TenHet }_{i}+\beta_{4} \text { LnAssets }_{i} \\
& +\beta_{5} \text { LnAge }_{i}+\beta_{6} \text { OutDir }_{i}+\beta_{7} \text { InsideOwn }_{i}+\beta_{8} \text { CEO } / \text { Chair }_{i}+\beta_{9} \text { CapEx }_{\text {I Assets }} 1_{i} \\
& +\beta_{10} \text { NI } / \text { Sales }-1_{i}+\varepsilon_{i}
\end{aligned}
$$

where the dependent variable is either $R \& D /$ Assets $-1, R \& D /$ Assets -2 , AveR\&D/Assets $-1 \&-2, \mathrm{LnR} \& \mathrm{D}$ $-1, \operatorname{LnR} \& \mathrm{D}-2$, or LnAveR\&D $-1 \&-2$, as described in the previous section. We also include industry dummies (at 4-digit SIC code level) and year dummies to capture industry and year effects. We expect a positive coefficient on the management quality factor score (MQFactor). Table 3 reports the results of our estimation. We find that MQFactor has a positive and statistically significant coefficient estimates in all regression specifications using all six measures of pre-IPO input to innovation as dependent variables. This positive relationship holds even after controlling for firm size, age, and industry and year dummies; firms with higher quality management teams invest significantly more in R\&D in the two-year period prior to their IPOs both in absolute dollar terms and as a proportion of their assets. These findings provide support for our hypothesis H1. Table 3 also shows that smaller firms, and those with more independent directors and less insider ownership invest more in R\&D prior to IPO as well. 


\subsubsection{OLS Analysis of the Relationship between Management Quality and Pre-IPO Innovation Output}

In this section we test hypothesis $\mathbf{H 2}$ in a multivariate regression setting. This hypothesis predicts that firms with higher management quality will be more innovative before their IPO as measured by the quantity as well as the quality of their innovation output. Our regression specification is as follows:

$$
\begin{aligned}
& \text { Dependent variable }_{i}=\beta_{0}+\beta_{1} \text { MQFactor }_{i}+\beta_{2} \text { Tenure }_{i}+\beta_{3} \text { TenHet }_{i}+\beta_{4} \text { LnAsset }_{i} \\
& +\beta_{5} \text { LnAge }_{i}+\beta_{6} \text { OutDir }_{i}+\beta_{7} \text { InsideOwn }_{i}+\beta_{8} \text { CEO } / \text { Chair }_{i}+\beta_{9} \text { CapEx } / \text { Assets }-1_{i} \\
& +\beta_{10} \text { NI / Sales }-1_{i}+\beta_{11} R \& D / \text { Assets }-1_{i}+\varepsilon_{i}
\end{aligned}
$$

where the dependent variables are LnCount -1 , LnCount -2 , LnCount $-1 \&-2$, LnCite -1 , LnCite -2 , or LnCite -1 \& -2 (as described in section 5.3). We also include industry dummies (at 4-digit SIC code level), year dummies, and as well as an additional control variable, $R \& D /$ Assets -1 , to control for the fact that firms which spend more on R\&D are likely to have a greater innovation output. We expect MQFactor to have positive coefficient estimates in our regressions. Table 4 reports the results of our estimation.

In regression 1, with LnCount -1 as the dependent variable, MQFactor has a significantly positive coefficient estimate even after controlling for firm size, age, industry and year dummies, and pre-IPO R\&D expenses. This indicates that firms with higher management quality are more innovative in pre-IPO year -1 as they produce significantly more patents in the year prior to their IPOs. In regression 2, with LnCount -2 as the dependent variable, MQFactor has a positive coefficient estimate which is not statistically significant. This indicates that management quality does not have a significant impact on the innovation output in year -2 prior to IPO. This latter finding is perhaps due to the fact that, as reported in Table 2, our sample firms, on average, produce significantly less patents in year -2 prior to their IPO compared to year -1 , even though they invest approximately the same amounts in R\&D both in years -1 and -2 prior to their IPOs. Given the lower number of patents produced in year -2 prior to IPO, it is not surprising that MQFactor has an insignificant coefficient estimate in regression 2. In regression 3, with LnCount $-1 \&-2$ as the dependent variable, MQFactor has a positive and significant coefficient estimate indicating that management quality significantly increases the total number of patents produced in the two-year period prior to IPO, providing support for our hypothesis $\mathbf{H 2}$. 
In regressions 4 through 6 , we use the number of citations per patent as our dependent variable. The results of these regressions are similar to those in regressions 1 through 3; management quality has a significantly positive impact on the quality of pre-IPO innovation (measured by the number of citations per patent) in year -1 prior to IPO; however the impact of management quality on the quality of pre-IPO innovation in year -2 prior to IPO is not statistically significant. As reported in Table 2, the patents produced by our sample firms in year -1 prior to IPO receive significantly more citations per patent (and, thus, are of higher quality) compared to those patents produced in year -2 prior to IPO. In regression 6 , with LnCite $-1 \&-2$ as the dependent variable, MQFactor has a positive and highly significant coefficient estimate indicating that management quality significantly increases the quality of patents produced in the two-year period prior to IPO. Overall, our findings in Table 4 indicate that management quality has a positive effect on the pre-IPO innovation output of private firms both in terms of the quantity as well as the quality of innovation, and provide support for our hypothesis $\mathbf{H 2}$.

\subsubsection{Instrumental Variable Analysis of the Effect of Management Quality on Pre-IPO Innovation}

We have shown above that management quality has a significantly positive effect on the pre-IPO input to innovation and on the pre-IPO innovation output (as measured by the quantity as well as the quality of innovation) of entrepreneurial firms. However, management quality may be potentially endogenous if more innovative firms attract higher quality managers.

We address the above endogeneity problem using IV analysis. We construct a suitable instrument for top management quality in two steps. First, we exploit the strong correlation between the movement of executives across firms and the number of acquisitions in the industry the firms belong to. It is well documented that many top managers of target firms in acquisitions leave their firms in the years immediately after an acquisition. ${ }^{23}$ It is also well documented that many private firms seek to build up their top management teams in the three to four years before an IPO (in preparation for their IPO) and at

${ }^{23}$ See, e.g., Krug and Shill (2008), who document that more than $30 \%$ of merged firms' top management team members leave their firms in the first year after the merger, that number dropping to roughly $20 \%$ in each of the three subsequent years after that. 
least a part of the supply of such experienced top managers comes from the top managers of established firms in the same industry who choose to move to another firm (due to their previous firm being acquired or for other reasons). ${ }^{24}$ Thus, in constructing our instrument, we use the above plausibly exogenous shock to the supply of top executives available for hire by a private firm, namely, the number of acquisitions of public firms in the industry and state of our sample firms in the three-year window prior to their IPOs. ${ }^{25}$

Second, the enforceability of non-compete clauses, which are commonly used in employment contracts for top management and prohibit them from joining or founding a rival company within one to two years of leaving, affects the mobility of managers across firms. ${ }^{26}$ Bishara, Martin, and Thomas (2015) analyze an extensive sample of CEO employment contracts and show that $80 \%$ of these contracts contain non-compete clauses, often with a broad geographic scope. A growing body of work (e.g., Garmaise (2009) and Marx, Strumsky, and Fleming (2009)) shows that higher enforceability of these non-compete clauses constrains employees' mobility (including those of managers). The enforceability of such noncompete clauses exhibits both cross-state and time series variation, which leads to variation in the mobility of managers that is unlikely to be related to corporate innovation.

In sum, using the above two steps, we construct an instrumental variable which proxies for a plausibly exogenous shock to the supply of managers available for hire by firms, making use of the strong correlation between industry acquisitions and the movement of top managers from public to private firms as well as the exogenous variation in the ability of managers to move due to non-compete clauses. Thus, the instrument we use is the number of acquisitions in the industry and state of the sample firm in the

\footnotetext{
${ }^{24}$ Of course, many top managers of acquired firms are subject to retention contracts that act as "golden handcuffs" for these managers, so that they may choose not to leave their firm in the years immediately after the firm employing them is acquired. However, it is worth noting that many such managers subject to retention contracts may nevertheless choose to move to private firms after their firm is acquired, since their future employer may compensate them for potential monetary losses. In any case, our instrument will be relevant as long as a significant number of top managers from public firms choose to move to private firms in the years immediately after their parent firm is acquired. We demonstrate the relevance of our instrument empirically later (in the first stage regressions of our IV analysis).

${ }^{25}$ We have constructed alternative versions of our instrument by also counting the number of acquisitions of public targets in industry $j$ in state $s$ in the previous four years as well as in previous two years. Our findings using these alternative versions of our instrument were similar to those reported in this paper.

${ }^{26}$ Since these non-compete clauses become operational only when top managers leave their prior firms, the enforceability of these non-compete clauses can be thought as a measure of the friction facing top managers when they attempt to join the current firm.
} 
three-year period prior to its IPO weighted by the reciprocal of one plus an index measuring the enforceability of non-compete clauses in that state. We therefore compute the instrument for the top management quality (MQFactor) of firm $i$ in industry $j$ in year $t$ as follows:

$$
\text { Instrument }_{j, t}=\text { Acquisitions }_{j, s, t} \times \frac{1}{1+\text { Enforceability Index }_{s, t}},
$$

where $j, s$, and $t$ stand for industry, state, and year, respectively. Acquisitions $s_{j, s, t}$ is the number of acquisitions of public targets in industry $j$ (identified by 2-digit SIC codes) in state $s$ in the three year period prior to firm i's IPO. We collect the information on the number of acquisitions from the SDC/Platinum Mergers \& Acquisitions database.

Enforceability Index $_{s, t}$ is the index of the enforceability of non-compete agreements in various U.S. states generated by Garmaise (2009). ${ }^{27}$ It ranges from zero (e.g., California) to nine (e.g., Florida after 1997), and higher values of this index indicate greater enforceability of non-compete agreements in a given state and thus less mobility of the managers from that state. Thus, we use the reciprocal of one plus the enforceability index to proxy for the ease with which managers from a given state can move to another job. The multiplication term, Acquisitions $j_{j, s, t} \times\left[1 /\left(1+\right.\right.$ Enforceability Index $\left.\left._{s, t}\right)\right]$, therefore proxies for the supply of managers who are able to move across firms and are available for hire from state $s$ in industry $j$ in year $t$. We expect higher values of this instrument to be positively correlated with top management quality (MQFactor). ${ }^{28}$

Clearly, the above instrument is likely to satisfy the exclusion restriction, since both components of the product in equation (3) are likely to be unrelated to the innovativeness of a sample firm. To further ensure that the exclusion restriction is satisfied, we include year fixed-effects in our IV analysis.

\footnotetext{
${ }^{27}$ Garmaise (2009) considers 12 questions analyzed by Malsberger (2004), which is the central resource describing noncompetition law in 50 U.S. states and the District of Columbia, and assigns one point to each jurisdiction for each question if the jurisdiction's enforcement of that dimension of noncompetition law exceeds a certain threshold. ${ }^{28}$ Chemmanur, Kong, Krishnan, and Yu (2018) use a similar instrument in their analysis of the relationship between top management quality and innovation in established firms. In an earlier version of their paper, Ewens and Marx (2018) make use of the number of acquisitions in a sample firm's industry as an instrument for the supply of managers. However, given that their dependent variable is successful exit (IPO or acquisition), they choose to use an alternative instrument in a later version of their paper given their fear that lagged acquisitions may affect the current exit market. Note, however, that we do not use the number of acquisitions as our instrument, but rather, the number of acquisitions weighted by the reciprocal of the enforceability index in the industry and state of the sample firm.
} 


\subsection{3a. IV Analysis of the Relationship between Management Quality and Pre-IPO Input to Innovation}

Table 5 presents the results of our IV analysis of the relationship between management quality and pre-IPO R\&D expenses. In regressions 1 through 5, we study the effect of management quality on pre-IPO input to innovation in year -1 prior to IPO and on the average pre-IPO input to innovation in years -1 and -2 . In these regressions we have 1,720 observations. In regressions 6 through 8 we study the effect of management quality on pre-IPO input to innovation in year -2 prior to IPO. Due to the scarcity of accounting data for year -2 prior to IPO, in regressions 6 through 8 we have only 809 observations. Regressions 1 and 6 present the first stage regressions of the management quality factor score (MQFactor) on our instrument and other control variables. The coefficient estimate of our instrument in regression 1 is positive and highly significant indicating a strong positive correlation between our instrument and MQFactor; the coefficient estimate of our instrument in regression 6 is also positive but not statistically significant (possibly due to a smaller number of observations used in that regression).

The first stage regressions in Table 5 also report the F-statistics of the weak instruments test (or the test of excluded instruments). This test is used to determine whether instrumental variables used in first stage regressions are strong. In their survey of the literature on weak instruments, Stock, Wright, and Yogo (2002) develop benchmarks for the necessary magnitude of the F-statistic. They indicate that if the number of instruments is equal to one, then the critical value of the F-statistic is 8.96. Since the F-statistic reported for regression 1 is above the critical value (10.18), the null hypothesis that our instrument is weak is rejected for our IV analysis. The F-statistic reported for regression 6 is 2.11, perhaps, as mentioned above, due to a smaller number of observations used in that regression.

Our second stage regressions $2,3,4$, and 5 demonstrate that management quality has a significantly positive effect on pre-IPO R\&D expenses in year -1 prior to IPO as well as on the average pre-IPO R\&D expenses in years -1 and -2 prior to IPO (our dependent variables in these regressions are $\mathrm{R} \& \mathrm{D} /$ Assets -1, AveR\&D/Assets $-1 \&-2$, LnR\&D -1, and LnAveR\&D -1 \& -2, respectively, as described in section 5.6). The coefficient estimates of MQFHat (the predicted value of MQFactor from first stage regression) in these regressions are positive and significant at the $1 \%, 5 \%$, and $10 \%$ levels. These results, 
consistent with our findings in baseline regressions, indicate that, even after controlling for the potential endogeneity of management quality, it still has a significantly positive effect on the input to innovation in entrepreneurial firms before their IPOs (especially in the year immediately prior to their IPOs). This provides further support for our hypothesis $\mathbf{H 1}$.

\subsection{3b. IV Analysis of the Relationship between Management Quality and Pre-IPO Innovation Output}

In Table 6 we present the results of our IV analysis of the relationship between management quality and pre-IPO innovation output. Regressions 1 and 6 are our first stage regressions of MQFactor on our instrument and other control variables. The coefficient estimates of our instrument in these regressions are positive and highly significant at the $1 \%$ level and the F-statistics are above the critical value (11.34 and 10.88 for regressions 1 and 6 , respectively). This indicates a strong positive correlation between our instrument and MQFactor and attests to the strength of our instrument.

Our second stage regressions $2,3,4$, and 5 show that management quality has a significantly positive effect on pre-IPO innovation output (our dependent variables in these regressions are LnCount 1, LnCount -1 \& -2, LnCite -1, and LnCite -1 \& -2, respectively). The coefficient estimates of MQFHat in these regressions are all positive and highly significant at the $1 \%$ and $5 \%$ levels indicating that, even after controlling for the potential endogeneity of top management quality, it still significantly increases both the quantity and the quality of pre-IPO innovation output of entrepreneurial firms (especially in the year immediately prior to their IPOs). These results provide further support for our hypothesis $\mathbf{H 2}$.

\subsection{The Effect of Management Quality on pre-IPO Innovation Strategies and Inventor Quality}

In this section, we investigate the channels through which top management quality of private firms is likely to affect their pre-IPO innovativeness. The channels we study are the various innovation strategies employed by entrepreneurial firms as well as the quality of inventors hired by them. 


\subsubsection{The Effect of Top Management Quality on Pre-IPO Innovation Strategies}

As described in detail in section 5.4, we make use of several variables to study the pre-IPO innovation strategies of entrepreneurial firms. First, we study the impact of top management quality on the fractions of explorative and exploitative patents produced by entrepreneurial firms in the two-year period prior to their IPOs. We run regressions as in equation (2) using ExplorRat and ExploitRat as dependent variables and report the results in columns 1 and 2 of Table 7, respectively. The coefficient estimates of MQFactor are positive in both regressions but statistically significant only in regression 1 with ExplorRat as the dependent variable. This suggests that private firms with higher top management quality are likely to produce a greater fraction of explorative patents compared to the private firms with lower top management quality. Further, we find that the coefficient estimate of MQFactor in regression 1 is statistically significantly larger than that in regression 2 suggesting that the positive effect of top management quality (in terms of fostering explorative and exploitative innovations) is much stronger in affecting explorative innovations and weaker in the case of exploitative innovations. This indicates that the higher the top management quality of private firms the more likely these firms to produce innovations which push the knowledge boundaries of the firm outward. These findings provide support for our hypothesis H3A and contradict our hypothesis H3B.

Second, we analyze the effect of top management quality of private firms on the nature of innovations produced by them by studying the number of times these firms' patents (produced in the twoyear period prior to their IPOs) cite other firms' patents (LnNSelfCite) and the number of times they cite their own firms' patents (LnSelfCite). The patents with more non-self-citations are likely to be more explorative in their nature whereas the patents with more self-citations are likely to be more exploitative. We run regressions as in equation (2) using LnNSelfCite and LnSelfCite as dependent variables and report the results in columns 3 and 4 of Table 7, respectively. The coefficient estimates of MQFactor are positive in both regressions but statistically significant only in regression 3 with LnNSelfCite as the dependent variable. This indicates that the patents of private firms with higher top management quality are likely to have more non-self-citations (be more explorative in their nature) compared with the patents 
of firms with lower top management quality. Further, we find that the coefficient estimate of MQFactor in regression 3 is statistically significantly greater than that in regression 4 suggesting that the positive effect of top management quality (in terms of fostering explorative and exploitative innovations) is much stronger in affecting explorative innovations (those with more non-self-citations) and weaker in the case of exploitative innovations (those with more self-citations). This indicates that the higher the top management quality of private firms the more likely these firms to produce innovations in areas that are new and less familiar to them. These findings provide further support for our hypothesis H3A and contradict our hypothesis H3B.

Finally, we also study the effect of top management quality of private firms on the degree of their patent portfolio's (produced in the two-year period prior to their IPOs) diversification across different technology classes. We run a regression as in equation (2) using Diversity as the dependent variable and report the results in column 5 of Table 7 . We find that MQFactor has a significantly positive coefficient estimate, implying that private firms with higher top management quality are likely to produce more diverse portfolios of patents (and thus pursue innovations in new and untested areas) compared to the firms with lower top management quality. This finding provides additional support for our hypothesis H3A and contradicts our hypothesis H3B.

The results of our IV analyses (using the same instrument for management quality as in section 6.1.3) for the above innovation strategy variables are reported in columns 1 through 6 of Table 8 . The first stage regression in column 1 is the same as in Table 6. Similar to our OLS regressions above, the second stage regressions of our IV analyses show that the top management quality of private firms has a significantly positive effect on the fraction of explorative patents produced by them (ExplorRat), the number of non-self-citations in the patents they produce (LnNSelfCite), and the degree of their patent portfolio diversification (Diversity). We also find a significantly positive coefficient estimate for MQFHat in second stage regression 5 with LnSelfCite as the dependent variable indicating that higher top management quality is associated with a larger number of self-citations as well. However, the coefficient estimate of MQFHat in regression 4 is almost ten times larger than that in regression 5 suggesting that the 
positive effect of management quality is stronger on the number of non-self-citations than on selfcitations. Thus, our IV analyses indicate that even after controlling for the potential endogeneity of top management quality, private firms with higher top management quality are more likely to pursue innovations which are explorative in their nature, supporting our hypothesis H3A and contradicting our hypothesis H3B.

\subsubsection{The Effect of Top Management Quality on Inventor Quality}

In this section we investigate the effect of top management quality of private firms on the quality of inventors working for such firms. Higher quality top management teams may enhance the innovation productivity of their firms by hiring higher quality (productivity) inventors. We run a regression as in equation (2) using our inventor quality variable InventorQual (defined in section 5.4) as the dependent variable and report the results in column 6 of Table 7. We find that the coefficient estimate of MQFactor is positive and statistically significant indicating that private firms with higher top management quality are likely to hire a larger number of higher quality inventors working for their firms, which, in turn, is likely to lead to higher innovation productivity of such firms.

In columns 1 and 7 of Table 8, we present the results of our IV analysis of inventor quality. The first stage regression (in column 1) is the same as in Table 6. Similar to our OLS regression above, the second stage regression of our IV analysis (in column 7) shows that, even after controlling for the potential endogeneity of top management quality, the top management quality of private firms has a significantly positive effect on the quality of inventors working for these firms. These finding provides support for our hypothesis $\mathbf{H} 4$.

\subsection{Relationship between Pre-IPO Innovation, Management Quality, and the IPO Market}

In this section, we test the hypotheses regarding the effect of management quality and pre-IPO innovation on IPO firm valuation, firm age at IPO, and the growth in post-IPO operating performance. 


\subsubsection{Relationship between Pre-IPO Innovation and IPO Firm Valuation}

We first test our hypothesis H5, which predicts that firms which are more innovative pre-IPO will receive higher valuations at IPO. We measure IPO firm valuation using Tobin's Q, which is the ratio of the market value of assets over the book value of assets, where the market value of assets is equal to the book value of assets minus the book value of equity plus the product of the number of shares outstanding and share price. We measure firm valuation in the IPO market by using the IPO offer price as the share price in the above definition (QOP) and we measure IPO firm valuation in the secondary market by using either the first trading day closing price as the share price in the above definition (QFTD) or the share price at the end of the IPO issue month (QIM). The book value of assets and the book value of equity are taken from the first available post-IPO quarter on Compustat. In constructing QOP and QFTD, the number of shares outstanding is as of the end of the first trading day; in constructing QIM, the number of shares outstanding is as of the end of the first available post-IPO fiscal quarter on Compustat.

To test our hypothesis H5, we regress various definitions of Q ratios (as described above) on a pre-IPO innovation output proxy (either LnCount $-1 \&-2$ or LnCite $-1 \&-2$ ) and other control. The results of these regressions are presented in Panel A of Table 9. In regressions 1 through 3 we use LnCount $-1 \&-2$ as a proxy for pre-IPO innovation productivity and in regressions 4 through 6 we use LnCite $-1 \&-2$ as a proxy for pre-IPO innovation productivity. We find that both pre-IPO innovation

productivity proxies have significantly positive coefficient estimates in all regressions (except for regression 2) indicating that firms which are more innovative pre-IPO receive higher valuations in both IPO and immediate secondary markets, supporting our hypothesis $\mathbf{H 5}$.

\subsubsection{Relationship between Pre-IPO Innovation, Management Quality, and IPO Firm Valuation}

Next, we investigate the joint effect of pre-IPO innovation productivity and management quality on IPO firm valuation. In order to study the joint effect of pre-IPO innovation productivity and management quality, we regress IPO firm valuation proxies on a dummy variable (either Q1Count or Q1Cite) and other control variables as in equation (1). These dummy variables are expected to capture the 
joint effect of pre-IPO innovation productivity and management quality. Dummy variable Q1Count takes a value of one for firms with above median MQFactor score and above median Count $-1 \&-2$. In other words, Q1Count takes a value of one for firms with high management quality and high pre-IPO innovation productivity measured by the quantity of pre-IPO innovation, and a value of zero for the remaining firms in our sample. Similarly, dummy variable Q1Cite takes a value of one for firms with above median MQFactor score and above median Cite -1 \& -2. Thus, Q1Cite takes a value of one for firms with high management quality and high pre-IPO innovation productivity measured by the quality of pre-IPO innovation, and a value of zero for the remaining firms in our sample.

We expect positive coefficients for Q1Count and Q1Cite if the joint effect of pre-IPO innovation and management quality on IPO firm valuation is positive. Regressions 1 through 3 in Panel B of Table 9 present the results of our estimation using Q1Count as an independent variable and regressions 4 through 6 present our results using Q1Cite as an independent variable. Both Q1Count and Q1Cite have positive and significant coefficient estimates in all regressions indicating that pre-IPO innovation productivity and management quality together have a significantly positive joint effect on IPO firm valuation both in the IPO (QOP) as well as in the immediate secondary market (QFTD or QIM). Thus, firms with both greater pre-IPO innovation productivity and higher management quality tend to receive the highest valuations in the IPO and immediate secondary market compared to the other firms in our sample. This finding provides support for our hypothesis H6.

\subsubsection{Relationship between Pre-IPO Innovation and Firm Age at IPO}

We now test our hypothesis $\mathbf{H 7}$, which predicts that firms which have greater innovation productivity pre-IPO will go public at a younger age. We test this hypothesis in the framework of a proportional hazard survival-time model. We consider firm age at IPO as the length of time a firm survives as a private company. In particular, we use maximum likelihood estimation for parametric regression survival-time model with Gompertz and Weibull survival distributions. The dependent variable in this estimation is the firm age (number of years from founding year to IPO year) which we regress on a 
pre-IPO innovation output proxy (either LnCount $-1 \&-2$ or LnCite $-1 \&-2$ ) and other control variables (we drop LnAge and year dummies as control variables in this estimation and cluster standard errors at year level). We expect positive coefficient estimates for LnCount $-1 \&-2$ or LnCite $-1 \&-2$ if the pre-IPO innovation productivity of private firms enables them to go public at a younger age. In proportional hazard survival-time models a positive coefficient estimate for an independent variable indicates that the hazard of not surviving (or, in our context, the likelihood of going public at a younger age) is increasing in that independent variable. The results of our analysis are presented in regressions 1 to 4 in Table 10 .

We find that both LnCount $-1 \&-2$ and LnCite $-1 \&-2$ have significantly positive coefficient estimates (except for regression 2) indicating that the hazard (of not surviving for longer period of time or, in other words, going public at a younger age) is increasing with pre-IPO innovation. These findings indicate that the greater pre-IPO innovation productivity (both in terms of quantity as well as the quality of innovation) of a private firm enables it to go public at a younger age, supporting our hypothesis $\mathbf{H 7}$.

\subsubsection{Relationship between Pre-IPO Innovation, Management Quality, and Firm Age at IPO}

We investigate the joint effect of pre-IPO innovation productivity and management quality on firm age at IPO in the same way as we did in section 6.3.2 when investigating the joint effect of pre-IPO innovation productivity and management quality on firm valuation. In particular, we estimate the effect of either Q1Count or Q1Cite (as defined in section 6.3.2) on firm age at IPO by making use of proportional hazard survival-time model with Gompertz and Weibull survival distributions. We expect positive coefficients for both Q1Count and Q1Cite if the joint effect of pre-IPO innovation productivity and management quality on firm age at IPO is negative. We report our findings in columns 5 to 8 in Table 10 .

We find that the coefficient estimates of Q1Count and Q1Cite in all four regressions are positive and significant at the 5\% level suggesting that firms which are more innovative pre-IPO and which have higher management quality are more likely to go public at a younger age compared to the other firms in our sample. These results provide support for our hypothesis $\mathbf{H 8}$. 


\subsubsection{Relationship between Pre-IPO Innovation and Post-IPO Operating Performance}

In this section, we test our hypothesis $\mathbf{H 9}$, which predicts that greater pre-IPO innovation productivity translates into higher growth rate in post-IPO operating performance of firms going public. We use the changes in post-IPO operating income before depreciation plus interest income scaled by total assets (OIBDA) as our measure for operating performance. Next, we construct the changes in OIBDA by subtracting the OIBDA in the year prior to the IPO (year -1) from the OIBDA in subsequent years (years 0 through 5 , where year 0 is the year of IPO).

To test our hypothesis H9, we run quantile/median regressions of the changes in post-IPO OIBDA on pre-IPO innovation productivity proxies and other controls. ${ }^{29}$ Our findings are presented in Panel A of Table 11. Regressions 1 through 6 use LnCount $-1 \&-2$ as a proxy of pre-IPO innovation productivity and regressions 7 through 12 use LnCite -1 \& -2 as a proxy of pre-IPO innovation productivity. We find that both pre-IPO innovation productivity proxies have a significantly positive effect on the changes in post-IPO operating performance (except for regressions 4 and 5). In particular, the effect of the quality of pre-IPO innovation on the changes in post-IPO operating performance is more pronounced than that of the quantity of pre-IPO innovation. Thus, our findings suggest that firms which are more innovative pre-IPO realize greater improvements in their post-IPO operating performance, supporting our hypothesis $\mathbf{H 9}$.

\subsubsection{Relation between Pre-IPO Innovation, Management Quality, and Post-IPO Operating Performance}

We now proceed to investigate the joint effect of the pre-IPO innovation productivity and the management quality of a private firm on the changes in its post-IPO operating performance. Similar to our analysis of the joint effect of pre-IPO innovation and management quality on IPO firm valuation and firm age at IPO, we regress (using quantile/median regressions) the changes in post-IPO operating

${ }^{29}$ We use quantile (median) regressions instead of OLS regressions given the large outliers in operating performance measures. Quantile (median) regressions estimate the conditional median of dependent variables given certain values of independent variables instead of the conditional mean estimated by OLS and thus are more appropriate here. 
performance measures on either Q1Count or Q1Cite (as described in section 6.3.2) and other control variables. We expect positive coefficients for both Q1Count and Q1Cite if the joint effect of the pre-IPO innovation productivity and the management quality of a private firm on the changes in its post-IPO operating performance is positive. Regressions 1 through 6 in Panel B of Table 11 present the results of our estimation using Q1Count as an independent variable and regressions 7 through 12 present our results using Q1Cite as an independent variable.

We find that both Q1Count and Q1Cite have positive and highly significant coefficient estimates in all regressions. This indicates that the joint effect of pre-IPO innovation productivity and management quality on the changes in post-IPO operating performance is significantly positive. Thus, firms which have greater pre-IPO innovation productivity (either in terms of the quantity or the quality of innovation) and higher management quality tend to realize the largest improvements in their post-IPO operating performance compared to the other firms in our sample. These findings provide support for our hypothesis H10.

\section{Conclusion}

We make use of hand-collected data on the top management quality of a large sample of private firms to address two research questions. First, how does the top management quality of a private firm affect its pre-IPO innovation productivity and innovation strategies? Second, how does the pre-IPO innovativeness and management quality of a firm affect its valuation at IPO, age at IPO, and post-IPO operating performance? We hypothesize that higher quality management teams hire higher quality scientists and other researchers, invest in more innovative projects, and manage these projects more ably, leading to higher innovation productivity. Consistent with this, we show in our baseline regressions in the first part of our analysis that firms with higher management quality are associated with higher innovation productivity in their pre-IPO years. The above relationship holds for measures of input to innovation (R\&D expenses) and for measures of innovation output such as the number of patents (innovation quantity) and citations per patent (innovation quality). We further show that firms with higher top 
management quality are more likely to produce explorative rather than exploitative innovations and are more likely to hire higher quality inventors. We use an IV analysis to establish that all the above relationships are causal. In the last part of our analysis, we find that the financial market rewards firms with greater pre-IPO innovativeness and higher management quality with higher valuations (both at IPO and in the immediate secondary market) and allows them to go public at a younger age. Consistent with this, such firms also exhibit higher growth in post-IPO operating performance. 


\section{References}

Acharya, V., Xu, Z., 2017. Financial Dependence and Innovation: The Case of Public versus Private Firms. Journal of Financial Economics 124 (2), 223-243.

Aggarwal, V.A., Hsu, D.H., 2014. Entrepreneurial Exits and Innovation. Management Science 60 (4), 867-887.

Aghion, P., Tirole, J., 1994. The Management of Innovation. Quarterly Journal of Economics 109 (4), $1185-1209$.

Aghion, P., Van Reenen, J., Zingales, L., 2013. Innovation and Institutional Ownership. American Economic Review 103 (1), 277-304.

Atanassov, J., 2013. Do Hostile Takeovers Stifle Innovation? Evidence from Antitakeover Legislation and Corporate Patenting. Journal of Finance 68 (3), 1097-1131.

Balsmeier, B., Fleming, L., Manso, G., 2017. Independent Boards and Innovation. Journal of Financial Economics 123 (3), 536-557.

Baranchuk, N., Kieschnick, R., Moussawi, R., 2014. Motivating Innovation in Newly Public Firms. Journal of Financial Economics 111 (3), 578-588.

Barker, V.L., Mueller, G.C., 2002. CEO Characteristics and Firm R\&D Spending. Management Science 48 (6), 782-801.

Becker, G.S., 1962. Investment in Human Capital: A Theoretical Analysis. Journal of Political Economy $70(5), 9-49$.

Bernstein, S., 2015. Does Going Public Affect Innovation? Journal of Finance 70 (4), 1365-1403.

Bertrand, M., Schoar, A., 2003. Managing with Style: The Effect of Managers on Firm Policies. Quarterly Journal of Economics 118 (4), 1169-1208.

Bishara, N.D., Martin, K.J., Thomas, R.S., 2015. An Empirical Analysis of Noncompetition Clauses and Other Restrictive Postemployment Covenants. Vanderbilt Law Review 68 (1), 1-51.

Borokhovich, K., Parrino, R., Trapani, T., 1996. Outside Directors and CEO Selection. Journal of Financial and Quantitative Analysis 31 (3), 337-355.

Brav, A., Jiang, W., Ma, S., Tian, X., 2018. How Does Hedge Fund Activism Reshape Corporate Innovation? Journal of Financial Economics, forthcoming.

Cao, J., Jiang, F., Ritter, J., 2015. Patents, Innovation, and Performance of Venture Capital-Backed IPOs. Singapore Management University, Central University of Finance and Economics, and University of Florida Working Paper.

Chemmanur, T.J., Fulghieri, P., 1999. A Theory of the Going-Public Decision. Review of Financial Studies 12 (2), 249-279. 
Chemmanur, T.J., Jiao, Y., 2012. Dual-Class IPOs: A Theoretical Analysis. Journal of Banking and Finance 36 (1), 305-319.

Chemmanur, T.J., Kong, L., Krishnan, K., Yu, Q., 2018. Top Management Human Capital, Inventor Mobility, and Corporate Innovation. Journal of Financial and Quantitative Analysis, forthcoming.

Chemmanur, T.J., Krishnan, K., 2012. Heterogeneous Beliefs, IPO Valuation, and the Economic Role of the Underwriter in IPOs. Financial Management 41 (4), 769-811.

Chemmanur, T.J., Loutskina, E., Tian, X., 2014. Corporate Venture Capital, Value Creation, and Innovation. Review of Financial Studies 27 (8), 2434-2473.

Chemmanur, T.J., Paeglis, I., 2005. Management Quality, Certification, and Initial Public Offerings. Journal of Financial Economics 76 (2), 331-368.

Chemmanur, T.J., Paeglis, I., Simonyan, K., 2011. Management Quality and Antitakeover Provisions. Journal of Law and Economics 54 (3), 651-692.

Chemmanur, T.J., Simonyan, K., Tehranian, H., 2016. The Effect of Venture Capital Backing on Top Management Quality and Implications for Initial Public Offerings. Boston College and Suffolk University Working Paper.

Chemmanur, T.J., Tian, X., 2018. Do Antitakeover Provisions Spur Corporate Innovation? A Regression Discontinuity Analysis. Journal of Financial and Quantitative Analysis 53 (3), 1163-1194.

Clementi, G., 2002. IPOs and the Growth of Firms. New York University Working Paper.

Cotter, J., Shivdasani, A., Zenner, M., 1997. Do Independent Directors Enhance Target Shareholder Wealth During Tender Offers? Journal of Financial Economics 43 (2), 195-218.

Custodio, C., Ferreira, M.A., Matos, P., 2017. Do General Managerial Skills Spur Innovation? Management Science, forthcoming.

D’Aveni, R., 1990. Top Managerial Prestige and Organizational Bankruptcy. Organization Science 1 (2), $121-142$.

Ederer, F., Manso, G., 2013. Is Pay for Performance Detrimental to Innovation? Management Science 59 (7), 1496-1513.

Ewens, M., Marx, M., 2018. Founder Replacement and Startup Performance. Review of Financial Studies $31(4), 1532-1565$.

Faleye, O., Hoitash, R., Hoitash, U., 2011. The Costs of Intense Board Monitoring. Journal of Financial Economics 101(1), 160-181.

Fama, E.F., Schwert, G.W., 1977. Human Capital and Capital Market Equilibrium. Journal of Financial Economics 4 (1), 95-125.

Ferreira, D., Manso, G., Silva, A.C., 2014. Incentives to Innovate and the Decision to Go Public or Private. Review of Financial Studies 27 (1), 256-300. 
Garmaise, M.J., 2009. Ties that Truly Bind: Noncompetition Agreements, Executive Compensation, and Firm Investment. Journal of Law, Economics, and Organization 27 (2), 376-425.

Gao, H., Hsu, P.-H., Li, K., 2018. Innovation Strategy of Private Firms. Journal of Financial and Quantitative Analysis 53 (1), 1-32.

Gaver, J., Gaver, K., 1993. Additional Evidence on the Association Between the Investment Opportunity Set and Corporate Financing, Dividend, and Compensation Policies. Journal of Accounting and Economics 16 (1-3), 125-160.

Griliches, Z., Pakes, A., Hall, B.H., 1987. The Value of Patents as Indicators of Inventive Activity. In Economic Policy and Technological Performance, eds. Dasgupta, P., Stoneman, P. (Cambridge University Press, Cambridge, UK).

Guay, W., 1999. The Sensitivity of CEO Wealth to Equity Risk: An Analysis of the Magnitude and Determinants. Journal of Financial Economics 53 (1), 43-71.

Hall, B.H., Jaffe, A.B., Trajtenberg, M., 2001. The NBER Patent Citations Data File: Lessons, Insights and Methodological Tools. NBER Working Paper No. 8498.

Hall, B.H., Jaffe, A.B., Trajtenberg, M., 2005. Market Value and Patent Citations. RAND Journal of Economics 36 (1), 16-38.

Hambrick, D., D'Aveni, R., 1992. Top Team Deterioration as Part of the Downward Spiral of Large Corporate Bankruptcies. Management Science 38 (10), 1445-1466.

Harman, H., 1976. Modern Factor Analysis, 3rd ed. (University of Chicago Press, Chicago, IL).

Hirshleifer, D., Low, A., Teoh, S.H., 2012. Are Overconfident CEOs Better Innovators? Journal of Finance 67 (4), 1457-1498.

Holmstrom, B., 1989. Agency Costs and Innovation. Journal of Economic Behavior and Organization 12 (3), 305-327.

Jain, B., Kini, O., 1994. The Post-Issue Operating Performance of IPO Firms. Journal of Finance 49 (5), 1699-1726.

Kogan, L., Papanikolaou, D., Seru, A., Stoffman, N., 2017. Technological Innovation, Resource Allocation, and Growth. Quarterly Journal of Economics 132 (2), 665-712.

Krug, J.A., Shill, W., 2008. The Big Exit: Executive Churn in the Wake of M\&As. Journal of Business Strategy 29 (4), 15-21.

Li, G.-C., Lai, R., D’Amour, A., Doolin, D.M., Sun, Y., Torvik, V.I., Yu, A.Z., Fleming, L., 2014. Disambiguation and Co-authorship Networks of the U.S. Patent Inventor Database (1975 - 2010). Research Policy 43 (6), 941-955.

Lerner, J., Sorensen, M., Stromberg, P., 2011. Private Equity and Long-Run Investment: The Case of Innovation. Journal of Finance 66 (2), 445-477. 
Lerner, J., Wulf, J., 2007. Innovation and Incentives: Evidence from Corporate R\&D. Review of Economics and Statistics 89 (4), 634-644.

Malsberger, B.M., 2004. Covenants Not to Compete: A State-by-State Survey. (BNA Books, Washington, DC).

Manso, G., 2011. Motivating Innovation. Journal of Finance 66 (5), 1823-1860.

Marx, M., Strumsky, D., Fleming, L., 2009. Mobility, Skills, and the Michigan Non-Compete Experiment. Management Science 55 (6), 875-889.

Megginson, W.L., Weiss, K.A., 1991. Venture Capitalist Certification in Initial Public Offerings. Journal of Finance 46 (3), 879-903.

Michaely, R., Shaw, W., 1994. The Pricing of Initial Public Offerings: Tests of Adverse Selection and Signaling Theories. Review of Financial Studies 7 (2), 279-319.

Mikkelson, W., Partch, M., Shah, K., 1997. Ownership and Operating Performance of Companies that Go Public. Journal of Financial Economics 44 (3), 281-307.

Pakes, A., 1985. On Patents, R\&D, and the Stock Market Rate of Return. Journal of Political Economy 93 (2), 390-409.

Porter, M.E., 1992. Capital Disadvantage: America's Failing Capital Investment System. Harvard Business Review 70 (5), 65-82.

Rechner, P.K., Dalton, D.R., 1991. CEO Duality and Organizational Performance: A Longitudinal Analysis. Strategic Management Journal 12 (2), 155-160.

Ritter, J., 1984. The Hot Issue Market of 1980. Journal of Business 57 (2), 215-240.

Ritter, J., Welch, I., 2002. A Review of IPO Activity, Pricing, and Allocations. Journal of Finance 57 (4), $1795-1828$.

Sapra, H., Subramanian, A., Subramanian, K.V., 2014. Corporate Governance and Innovation: Theory and Evidence. Journal of Financial and Quantitative Analysis 49 (4), 957-1003.

Seru, A., 2014. Firm Boundaries Matter: Evidence from Conglomerates and R\&D Activity. Journal of Financial Economics 111 (2), 381-405.

Sorensen, J.B., Stuart, T.E., 2000. Aging, Obsolescence, and Organizational Innovation. Administrative Science Quarterly 45 (1), 81-112.

Spiegel, M., Tookes, H., 2016. Identifying an IPO's Impact on Rival Firms. Yale University Working Paper.

Stein, J.C., 1988. Takeover Threats and Managerial Myopia. Journal of Political Economy 96 (1), 61-80.

Stein, J.C., 1989. Efficient Capital Markets, Inefficient Firms: A Model of Myopic Corporate Behavior. Quarterly Journal of Economics 104 (4), 655-669. 
Stock, J.H., Wright, J.H., Yogo, M., 2002. A Survey of Weak Instruments and Weak Identification in Generalized Method of Moments. Journal of Business and Economic Statistics 20 (4), 518-529.

Tian, X., Wang, T., 2014. Tolerance for Failure and Corporate Innovation. Review of Financial Studies $27(1), 211-255$.

Yermack, D., 1997. Good Timing: CEO Stock Option Awards and Company News Announcements. Journal of Finance 52 (2), 449-476. 
Table 1. Common factor analysis of eight individual measures of top management quality and reputation

The sample consists of 1,851 venture-backed IPOs conducted between 1993 and 2004 . MQFactor is the management quality factor score obtained using common factor analysis on the firm-size-, firmage-, and industry-dummies-adjusted TSize, MBA, PriorExp, LawAcc, CPA, Core, CEODom, and Board. TSize is the size of a firm's management team, defined as the number of executive officer with a rank of vice president or higher. MBA is the number of management team members with MBA degrees. PriorExp is the number of management team members who have served as executive officers and/or vice presidents at other firms prior to joining the IPO firm. Core is the number of management team members who have core functional expertise, namely, holding positions in operation and production, sales and marketing, research and development, and finance. LawAcc is the number of management team members who have previously been partners in law or accounting firms. CPA is the number of management team members who are Certified Public Accountants. CEODom is the ratio of CEO salary and bonus to the average salary and bonus of other management team members in the fiscal year prior to IPO. Board is the number of other companies' boards that management team members sit on.

Panel A. Estimated communalities of eight management quality measures

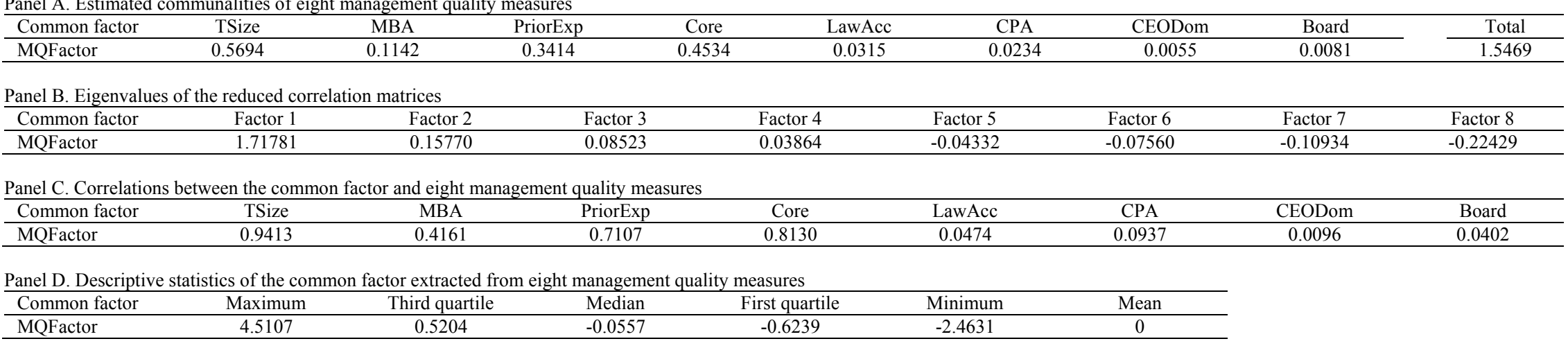


Table 2. Summary statistics

LnCount -1 , LnCount -2 , and LnCount $-1 \&-2$ are the natural logarithms of one plus the number of patents a firm files for (and is eventually granted) in years $-1,-2$, and -1 and -2 combined, respectively, prior to IPO. LnCite -1 , LnCite -2 , and LnCite $-1 \&-2$ are the natural logarithms of one plus the number of non-self-citations per patent a firm files for (and is eventually granted) in years $-1,-2$, and -1 and -2 combined, respectively, prior to IPO. $\mathrm{R} \& \mathrm{D} /$ Assets -1 and $\mathrm{R} \& \mathrm{D} /$ Assets -2 are the ratios of $\mathrm{R} \& \mathrm{D}$ expenses to assets in fiscal years -1 and -2 , respectively, prior to IPO. AveR\&D/Assets $-1 \&-2$ is the average ratio of R\&D expenses to assets in fiscal years -1 and -2 prior to IPO. LnR\&D -1 and LnR\&D -2 are the natural logarithms of R\&D expenses in fiscal years -1 and -2 , respectively, prior to IPO. LnAveR\&D $-1 \&-2$ is the natural logarithm of average R\&D expenses in fiscal years -1 and -2 prior to IPO. ExplorRat is the fraction of explorative patents out of all the patents applied by a firm in the two-year period prior to its IPO. ExploitRat is the fraction of exploitative patents out of all the patents applied by a firm in the two-year period prior to its IPO. LnNSelfCite and LnSelfCite are the natural logarithms of one plus the number of non-self-citations (i.e., the number of times that a firm cites patents owned by other firms) and the number of self-citations, respectively, of all the patents cited by a firm over the two-year period prior to its IPO. Diversity equals one minus the Herfindahl index of the number of patents filed by a firm over the twoyear period prior to its IPO across various technological classes. InventorQual is the natural logarithm of one plus the number of inventors whose patents were filed by a firm in the two-year period prior to its IPO and who receive top $10 \%$ of the citations across various technological classes. MQFactor is the management quality factor score obtained using common factor analysis on the firm-size-, firm-age-, and industry-dummiesadjusted TSize, MBA, PriorExp, LawAcc, CPA, Core, CEODom, and Board. TSize is the size of a firm's management team, defined as the number of executive officers with a rank of vice president or higher. PMBA is the percentage of a firm's management team with MBA degrees. PPriorExp is the percentage of a firm's management team who have served as executive officers and/or vice presidents prior to joining the IPO firm. PCore is the percentage of a firm's management team who have core functional expertise, namely, holding positions in operations and production, sales and marketing, R\&D, and finance. PLawAcc is the percentage of a firm's management team who have previously been partners in law or accounting firms. PCPA is the percentage of a firm's management team who are Certified Public Accountants. CEODom is the ratio of CEO salary and bonus to the average salary and bonus of other management team members in the fiscal year prior to IPO. Board is the number of other companies' boards that management team members sit on. Tenure is the average number of years a firm's management team members have been with the firm. TenHet is the coefficient of variation of management team members' tenures. LnAssets is the natural logarithm of the book value of assets immediately prior to IPO. LnAge is the natural logarithm of one plus firm age. OutDir is the proportion of outside directors in the board of directors. InsideOwn is the proportion of voting power owned by firm officers and directors immediately prior to IPO. CEO/Chair is an indicator variable equal to one if a CEO is also a Chairman of the board of directors, and zero otherwise. CapEx/Assets -1 is the ratio of capital expenditures over assets in fiscal year -1 prior to IPO. NI/Sales -1 is the ratio of net income to sales in fiscal year -1 prior to IPO.

\begin{tabular}{|c|c|c|c|c|c|c|}
\hline Variables & $\mathrm{N}$ & Min & Mean & Median & Max & St.Dev. \\
\hline \multicolumn{7}{|c|}{ Innovation variables } \\
\hline LnCount -1 & 1,833 & 0 & 0.184 & 0 & 4.166 & 0.570 \\
\hline LnCount -2 & 1,765 & 0 & 0.016 & 0 & 4.146 & 0.200 \\
\hline LnCount $-1 \&-2$ & 1,833 & 0 & 0.189 & 0 & 4.841 & 0.586 \\
\hline LnCite -1 & 1,833 & 0 & 0.337 & 0 & 5.491 & 0.990 \\
\hline LnCite -2 & 1,765 & 0 & 0.020 & 0 & 4.131 & 0.259 \\
\hline LnCite $-1 \&-2$ & 1,833 & 0 & 3.185 & 0 & 241.445 & 12.970 \\
\hline $\mathrm{R} \& \mathrm{D} /$ Assets -1 & 1,834 & 0 & 0.258 & 0.148 & 4.936 & 0.405 \\
\hline $\mathrm{R} \& \mathrm{D} /$ Assets -2 & 852 & 0 & 0.325 & 0.175 & 4.721 & 0.546 \\
\hline AveR\&D/Assets $-1 \&-2$ & 1,834 & 0 & 0.272 & 0.160 & 4.194 & 0.406 \\
\hline LnR\&D -1 & 1,834 & 0 & 10.259 & 14.498 & 20.364 & 7.127 \\
\hline LnR\&D -2 & 852 & 0 & 9.996 & 14.158 & 20.496 & 7.110 \\
\hline LnAveR\&D -1 \& -2 & 1,837 & 0 & 10.063 & 14.168 & 20.432 & 7.007 \\
\hline ExplorRat & 1,833 & 0 & 0.291 & 0 & 1 & 0.438 \\
\hline ExploitRat & 1,833 & 0 & 0.013 & 0 & 1 & 0.081 \\
\hline LnNSelfCite & 1,833 & 0 & 1.046 & 0 & 8.494 & 1.947 \\
\hline LnSelfCite & 1,833 & 0 & 0.099 & 0 & 4.331 & 0.449 \\
\hline Diversity & 1,833 & 0 & 0.101 & 0 & 0.935 & 0.227 \\
\hline InventorQual & 1,833 & 0 & 0.373 & 0 & 5.069 & 0.954 \\
\hline \multicolumn{7}{|c|}{ Management quality variables } \\
\hline MQFactor & 1,851 & -2.463 & 0 & -0.056 & 4.511 & 0.908 \\
\hline TSize & 1,851 & 1 & 6.782 & 6 & 19 & 2.515 \\
\hline PMBA & 1,851 & 0 & 0.156 & 0.111 & 1 & 0.187 \\
\hline PPriorExp & 1,851 & 0 & 0.554 & 0.571 & 1 & 0.263 \\
\hline PCore & 1,851 & 0 & 0.592 & 0.6 & 1 & 0.202 \\
\hline PLawAcc & 1,851 & 0 & 0.024 & 0 & 1 & 0.075 \\
\hline PCPA & 1,851 & 0 & 0.066 & 0 & 1 & 0.106 \\
\hline CEODom & 1,851 & 0 & 1.293 & 1.263 & 4.521 & 0.461 \\
\hline Board & 1,851 & 0 & 0.527 & 0 & 10 & 1.069 \\
\hline Tenure & 1,851 & 1 & 4.431 & 3.286 & 30 & 3.512 \\
\hline TenHet & 1,851 & 0 & 0.689 & 0.573 & 16.408 & 0.868 \\
\hline \multicolumn{7}{|c|}{ Control variables } \\
\hline LnAssets & 1,851 & 12.683 & 17.242 & 17.024 & 22.969 & 1.447 \\
\hline LnAge & 1,851 & 0 & 2.044 & 1.946 & 5.063 & 0.779 \\
\hline OutDir & 1,851 & 0 & 0.697 & 0.714 & 1 & 0.179 \\
\hline InsideOwn & 1,851 & 0 & 0.572 & 0.590 & 1 & 0.262 \\
\hline CEO/Chair & 1,851 & 0 & 0.558 & 1 & 1 & 0.497 \\
\hline CapEx/Assets -1 & 1,834 & 0 & 0.091 & 0.059 & 0.882 & 0.105 \\
\hline NI/Sales -1 & 1,720 & -1763.966 & -7.386 & -0.092 & 2.787 & 65.360 \\
\hline
\end{tabular}


Table 3. Relationship between management quality and pre-IPO input to innovation (R\&D expenses)

The sample consists of 1,851 venture-backed IPOs conducted between 1993 and 2004. R\&D/Assets -1 is the ratio of R\&D expenses to assets in fiscal year -1 prior to IPO. R\&D/Assets -2 is the ratio of $R \& D$ expenses to assets in fiscal year -2 prior to IPO. AveR\&D/Assets $-1 \&-2$ is the average ratio of $R \& D$ expenses to assets in fiscal years -1 and -2 prior to IPO. LnR\&D -1 is the natural logarithm of R\&D expenses in fiscal year -1 prior to IPO. LnR\&D -2 is the natural logarithm of R\&D expenses in fiscal year -2 prior to IPO. LnAveR\&D $-1 \&-2$ is the natural logarithm of average R\&D expenses in fiscal years -1 and -2 prior to IPO. MQFactor is the management quality factor score obtained using common factor analysis on the firm-size-, firm-age-, and industry-dummies-adjusted TSize, MBA, PriorExp, LawAcc, CPA, Core, CEODom, and Board. Tenure is the average number of years a firm's management team members have been with the firm. TenHet is the coefficient of variation of management team members' tenures. LnAssets is the natural logarithm of the book value of assets immediately prior to IPO. LnAge is the natural logarithm of one plus firm age. OutDir is the proportion of outside directors in the board of directors. InsideOwn is the proportion of voting power owned by firm officers and directors immediately prior to IPO. CEO/Chair is an indicator variable equal to one if a CEO is also a Chairman of the board of directors, and zero otherwise. CapEx/Assets -1 is the ratio of capital expenditures over assets in fiscal year -1 prior to IPO. NI/Sales -1 is the ratio of net income to sales in fiscal year -1 prior to IPO. All regressions include 4-digit SIC industry code dummies and year dummies. $t$-statistics are in parentheses. ${ }^{* * *},{ }^{* *}$, and ${ }^{*}$ indicate significance at the 1,5 , and 10 percent levels, respectively.

\begin{tabular}{|c|c|c|c|c|c|c|}
\hline & (1) & (2) & (3) & (4) & (5) & (6) \\
\hline Dependent variable & R\&D/Assets -1 & R\&D/Assets -2 & AveR\&D/Assets $-1 \&-2$ & LnR\&D -1 & LnR\&D -2 & LnAveR\&D -1 \& -2 \\
\hline Constant & $\begin{array}{c}1.483 \\
(4.09)^{* * *}\end{array}$ & $\begin{array}{c}2.183 \\
(3.51)^{* * *}\end{array}$ & $\begin{array}{c}1.626 \\
(4.22)^{* * *}\end{array}$ & $\begin{array}{c}27.042 \\
(4.89)^{* * *}\end{array}$ & $\begin{array}{c}26.604 \\
(4.60) * * *\end{array}$ & $\begin{array}{c}26.561 \\
(4.90)^{* * *}\end{array}$ \\
\hline MQFactor & $\begin{array}{c}0.016 \\
(1.76)^{*}\end{array}$ & $\begin{array}{c}0.043 \\
(1.98)^{* *}\end{array}$ & $\begin{array}{c}0.020 \\
(2.15)^{* *}\end{array}$ & $\begin{array}{c}0.845 \\
(6.22)^{* * *}\end{array}$ & $\begin{array}{c}0.945 \\
(4.64)^{* * *}\end{array}$ & $\begin{array}{c}0.825 \\
(6.19)^{* * *}\end{array}$ \\
\hline Tenure & $\begin{array}{c}-0.007 \\
(-2.00)^{* *}\end{array}$ & $\begin{array}{l}-0.002 \\
(-0.28)\end{array}$ & $\begin{array}{l}-0.006 \\
(-1.50)\end{array}$ & $\begin{array}{l}-0.029 \\
(-0.54)\end{array}$ & $\begin{array}{l}0.056 \\
(0.72)\end{array}$ & $\begin{array}{l}-0.021 \\
(-0.40)\end{array}$ \\
\hline TenHet & $\begin{array}{l}-0.002 \\
(-0.25)\end{array}$ & $\begin{array}{l}-0.069 \\
(-0.82)\end{array}$ & $\begin{array}{l}-0.004 \\
(-0.35)\end{array}$ & $\begin{array}{l}0.087 \\
(0.57)\end{array}$ & $\begin{array}{l}0.138 \\
(0.18)\end{array}$ & $\begin{array}{l}0.092 \\
(0.61)\end{array}$ \\
\hline LnAssets & $\begin{array}{c}-0.094 \\
(-12.97)^{* * *}\end{array}$ & $\begin{array}{c}-0.135 \\
(-6.90) * * *\end{array}$ & $\begin{array}{c}-0.103 \\
(-13.38)^{* * *}\end{array}$ & $\begin{array}{c}-0.860 \\
(-7.76)^{* * *}\end{array}$ & $\begin{array}{c}-0.965 \\
(-5.28)^{* * *}\end{array}$ & $\begin{array}{c}-0.853 \\
(-7.84)^{* * *}\end{array}$ \\
\hline LnAge & $\begin{array}{l}0.005 \\
(0.34)\end{array}$ & $\begin{array}{l}-0.001 \\
(-0.03)\end{array}$ & $\begin{array}{l}0.005 \\
(0.31)\end{array}$ & $\begin{array}{l}0.084 \\
(0.38)\end{array}$ & $\begin{array}{c}0.693 \\
(1.91)^{*}\end{array}$ & $\begin{array}{l}0.098 \\
(0.46)\end{array}$ \\
\hline OutDir & $\begin{array}{l}0.058 \\
(1.24)\end{array}$ & $\begin{array}{l}0.093 \\
(0.73)\end{array}$ & $\begin{array}{l}0.068 \\
(1.36)\end{array}$ & $\begin{array}{c}2.130 \\
(2.97)^{* * *}\end{array}$ & $\begin{array}{c}2.420 \\
(2.03)^{* *}\end{array}$ & $\begin{array}{c}2.054 \\
(2.92)^{* * *}\end{array}$ \\
\hline InsideOwn & $\begin{array}{c}-0.068 \\
(-2.17)^{* *}\end{array}$ & $\begin{array}{l}-0.138 \\
(-1.62)\end{array}$ & $\begin{array}{c}-0.076 \\
(-2.28)^{* *}\end{array}$ & $\begin{array}{l}-0.898 \\
(-1.88)^{*}\end{array}$ & $\begin{array}{l}-0.879 \\
(-1.11)\end{array}$ & $\begin{array}{l}-0.891 \\
(-1.90)^{*}\end{array}$ \\
\hline CEO/Chair & $\begin{array}{c}-0.033 \\
(-2.07)^{* *}\end{array}$ & $\begin{array}{c}0.066 \\
(1.66)^{*}\end{array}$ & $\begin{array}{l}-0.020 \\
(-1.17)\end{array}$ & $\begin{array}{l}-0.097 \\
(-0.40)\end{array}$ & $\begin{array}{l}-0.078 \\
(-0.21)\end{array}$ & $\begin{array}{l}-0.117 \\
(-0.49)\end{array}$ \\
\hline CapEx/Assets -1 & $\begin{array}{c}0.435 \\
(5.42)^{* * *}\end{array}$ & $\begin{array}{c}-0.494 \\
(-2.35)^{* *}\end{array}$ & $\begin{array}{c}0.280 \\
(3.28)^{* * *}\end{array}$ & $\begin{array}{l}-1.072 \\
(-0.87)\end{array}$ & $\begin{array}{c}-5.989 \\
(-3.06)^{* * *}\end{array}$ & $\begin{array}{l}-1.139 \\
(-0.95)\end{array}$ \\
\hline NI/Sales -1 & $\begin{array}{c}-0.000 \\
(-2.21)^{* *}\end{array}$ & $\begin{array}{l}-0.000 \\
(-1.36)\end{array}$ & $\begin{array}{c}-0.000 \\
(-2.15)^{* *}\end{array}$ & $\begin{array}{l}-0.000 \\
(-0.17)\end{array}$ & $\begin{array}{c}0.000 \\
(0.11)\end{array}$ & $\begin{array}{l}-0.000 \\
(-0.21)\end{array}$ \\
\hline Industry Dummies & Yes & Yes & Yes & Yes & Yes & Yes \\
\hline Year Dummies & Yes & Yes & Yes & Yes & Yes & Yes \\
\hline $\mathrm{N}$ & 1,720 & 809 & 1,720 & 1,720 & 809 & 1,720 \\
\hline $\mathrm{R}^{2}$ & 0.4284 & 0.3103 & 0.4055 & 0.6780 & 0.7066 & 0.6788 \\
\hline
\end{tabular}


Table 4. Relationship between management quality and the quantity and quality of pre-IPO innovation

The sample consists of 1,851 venture-backed IPOs conducted between 1993 and 2004. LnCount -1 is the natural logarithm of one plus the number of patents a firm files for (and is eventually granted) in year -1 prior to IPO. LnCount -2 is the natural logarithm of one plus the number of patents a firm files for (and is eventually granted) in year -2 prior to IPO. LnCount $-1 \&-2$ is the natural logarithm of one plus the number of patents a firm files for (and is eventually granted) in years -1 and -2 combined prior to IPO. LnCite -1 is the natural logarithm of one plus the number of non-self-citations per patent a firm files for (and is eventually granted) in year -1 prior to IPO. LnCite -2 is the natural logarithm of one plus the number of non-self-citations per patent a firm files for (and is eventually granted) in year -2 prior to IPO. LnCite $-1 \&-2$ is the natural logarithm of one plus the number of non-self-citations per patent a firm files for (and is eventually granted) in years -1 and -2 combined prior to IPO. MQFactor is the management quality factor score obtained using common factor analysis on the firm-size-, firm-age-, and industrydummies-adjusted TSize, MBA, PriorExp, LawAcc, CPA, Core, CEODom, and Board. Tenure is the average number of years a firm's management team members have been with the firm. TenHet is the coefficient of variation of management team members' tenures. LnAssets is the natural logarithm of the book value of assets immediately prior to IPO. LnAge is the natural logarithm of one plus firm age. OutDir is the proportion of outside directors in the board of directors. InsideOwn is the proportion of voting power owned by firm officers and directors immediately prior to IPO. CEO/Chair is an indicator variable equal to one if a CEO is also a Chairman of the board of directors, and zero otherwise. CapEx/Assets -1 is the ratio of capital expenditures over assets in fiscal year -1 prior to IPO. NI/Sales -1 is the ratio of net income to sales in fiscal year -1 prior to IPO. R\&D/Assets -1 is the ratio of R\&D expenses to assets in fiscal year -1 prior to IPO. All regressions include 4digit SIC industry code dummies and year dummies. $t$-statistics are in parentheses. ${ }^{* *},{ }^{* *}$, and $*$ indicate significance at the 1,5 , and 10 percent levels, respectively.

\begin{tabular}{|c|c|c|c|c|c|c|}
\hline & (1) & (2) & (3) & (4) & (5) & (6) \\
\hline Dependent variable & LnCount -1 & LnCount -2 & LnCount $-1 \&-2$ & LnCite -1 & LnCite -2 & LnCite $-1 \&-2$ \\
\hline Constant & $\begin{array}{l}-0.892 \\
(-1.38)\end{array}$ & $\begin{array}{l}-0.333 \\
(-1.39)\end{array}$ & $\begin{array}{l}-0.960 \\
(-1.45)\end{array}$ & $\begin{array}{l}-0.348 \\
(-0.30)\end{array}$ & $\begin{array}{l}-0.435 \\
(-1.39)\end{array}$ & $\begin{array}{l}-0.447 \\
(-0.38)\end{array}$ \\
\hline MQFactor & $\begin{array}{c}0.034 \\
(2.15)^{* *}\end{array}$ & $\begin{array}{l}0.000 \\
(0.07)\end{array}$ & $\begin{array}{c}0.035 \\
(2.12)^{* *}\end{array}$ & $\begin{array}{c}0.103 \\
(3.52)^{* * *}\end{array}$ & $\begin{array}{l}0.007 \\
(0.85)\end{array}$ & $\begin{array}{c}0.102 \\
(3.47)^{* * *}\end{array}$ \\
\hline Tenure & $\begin{array}{l}-0.002 \\
(-0.33)\end{array}$ & $\begin{array}{l}-0.001 \\
(-0.47)\end{array}$ & $\begin{array}{l}-0.001 \\
(-0.18)\end{array}$ & $\begin{array}{l}0.008 \\
(0.73)\end{array}$ & $\begin{array}{l}0.001 \\
(0.32)\end{array}$ & $\begin{array}{l}0.009 \\
(0.78)\end{array}$ \\
\hline TenHet & $\begin{array}{l}-0.004 \\
(-0.22)\end{array}$ & $\begin{array}{l}-0.003 \\
(-0.50)\end{array}$ & $\begin{array}{l}-0.005 \\
(-0.25)\end{array}$ & $\begin{array}{l}-0.011 \\
(-0.33)\end{array}$ & $\begin{array}{l}-0.004 \\
(-0.52)\end{array}$ & $\begin{array}{l}-0.012 \\
(-0.37)\end{array}$ \\
\hline LnAssets & $\begin{array}{c}0.037 \\
(2.66)^{* * *}\end{array}$ & $\begin{array}{c}0.014 \\
(2.73)^{* * *}\end{array}$ & $\begin{array}{c}0.039 \\
(2.77)^{* * *}\end{array}$ & $\begin{array}{l}0.022 \\
(0.89)\end{array}$ & $\begin{array}{c}0.017 \\
(2.44)^{* *}\end{array}$ & $\begin{array}{l}0.026 \\
(1.03)\end{array}$ \\
\hline LnAge & $\begin{array}{l}0.028 \\
(1.07)\end{array}$ & $\begin{array}{l}0.016 \\
(1.52)\end{array}$ & $\begin{array}{l}0.029 \\
(1.07)\end{array}$ & $\begin{array}{l}0.006 \\
(0.12)\end{array}$ & $\begin{array}{l}0.017 \\
(1.21)\end{array}$ & $\begin{array}{l}0.008 \\
(0.15)\end{array}$ \\
\hline OutDir & $\begin{array}{c}-0.166 \\
(-1.98)^{* *}\end{array}$ & $\begin{array}{l}-0.007 \\
(-0.21)\end{array}$ & $\begin{array}{c}-0.160 \\
(-1.86)^{*}\end{array}$ & $\begin{array}{l}-0.109 \\
(-0.71)\end{array}$ & $\begin{array}{l}-0.013 \\
(-0.31)\end{array}$ & $\begin{array}{l}-0.112 \\
(-0.73)\end{array}$ \\
\hline InsideOwn & $\begin{array}{l}-0.050 \\
(-0.89)\end{array}$ & $\begin{array}{l}-0.024 \\
(-1.12)\end{array}$ & $\begin{array}{l}-0.054 \\
(-0.94)\end{array}$ & $\begin{array}{l}-0.007 \\
(-0.06)\end{array}$ & $\begin{array}{l}-0.004 \\
(-0.15)\end{array}$ & $\begin{array}{l}-0.002 \\
(-0.02)\end{array}$ \\
\hline CEO/Chair & $\begin{array}{c}-0.048 \\
(-1.71)^{*}\end{array}$ & $\begin{array}{l}-0.004 \\
(-0.40)\end{array}$ & $\begin{array}{l}-0.050 \\
(-1.71)^{*}\end{array}$ & $\begin{array}{c}-0.124 \\
(-2.40)^{* *}\end{array}$ & $\begin{array}{l}0.002 \\
(0.16)\end{array}$ & $\begin{array}{c}-0.115 \\
(-2.20)^{* *}\end{array}$ \\
\hline CapEx/Assets -1 & $\begin{array}{l}0.130 \\
(0.90)\end{array}$ & $\begin{array}{l}0.012 \\
(0.22)\end{array}$ & $\begin{array}{l}0.140 \\
(0.94)\end{array}$ & $\begin{array}{l}-0.076 \\
(-0.29)\end{array}$ & $\begin{array}{l}0.021 \\
(0.29)\end{array}$ & $\begin{array}{l}-0.039 \\
(-0.15)\end{array}$ \\
\hline NI/Sales -1 & $\begin{array}{l}0.000 \\
(0.50)\end{array}$ & $\begin{array}{l}0.000 \\
(0.17)\end{array}$ & $\begin{array}{l}0.000 \\
(0.54)\end{array}$ & $\begin{array}{l}0.001 \\
(1.25)\end{array}$ & $\begin{array}{l}0.000 \\
(0.06)\end{array}$ & $\begin{array}{l}0.001 \\
(1.25)\end{array}$ \\
\hline R\&D/Assets -1 & $\begin{array}{c}0.132 \\
(2.78)^{* * *}\end{array}$ & $\begin{array}{l}0.020 \\
(1.15)\end{array}$ & $\begin{array}{c}0.142 \\
(2.92)^{* * *}\end{array}$ & $\begin{array}{c}0.161 \\
(1.86)^{*}\end{array}$ & $\begin{array}{l}0.034 \\
(1.46)\end{array}$ & $\begin{array}{c}0.184 \\
(2.11)^{* *}\end{array}$ \\
\hline Industry Dummies & Yes & Yes & Yes & Yes & Yes & Yes \\
\hline $\begin{array}{l}\text { Year Dummies } \\
\mathrm{N}\end{array}$ & $\frac{\text { Yes }}{1706}$ & $\frac{\text { Yes }}{1661}$ & $\frac{\text { Yes }}{1706}$ & $\frac{\text { Yes }}{1706}$ & Yes & $\begin{array}{c}\text { Yes } \\
1.706\end{array}$ \\
\hline $\mathrm{R}^{2}$ & 0.1250 & 0.0474 & 0.1276 & 0.0946 & 0.0322 & 0.0955 \\
\hline
\end{tabular}


Table 5. Instrumental variable analysis of the effect of management quality on pre-IPO input to innovation (R\&D expenses)

The sample consists of 1,851 venture-backed IPOs conducted between 1993 and 2004. In first stage regressions, dependent variable MQFactor is the management quality factor score obtained using common factor analysis on the firm-size-, firm-age-, and industry-dummies-adjusted TSize, MBA, PriorExp, LawAcc, CPA, Core, CEODom, and Board. In second stage regressions, dependent variable R\&D/Assets 1 is the ratio of R\&D expenses to assets in fiscal year -1 prior to IPO, AveR\&D/Assets $-1 \&-2$ is the average ratio of R\&D expenses to assets in fiscal years -1 and -2 prior to IPO, LnR\&D -1 is the natural logarithm of R\&D expenses in fiscal year -1 prior to IPO, LnAveR\&D -1 \& -2 is the natural logarithm of average R\&D expenses in fiscal years -1 and -2 prior to IPO, R\&D/Assets -2 is the ratio of R\&D expenses to assets in fiscal year -2 prior to IPO, and LnR\&D -2 is the natural logarithm of R\&D expenses in fiscal year -2 prior to IPO. In second stage regressions MQFHat is the predicted value of $\mathrm{MQFactor}$ from the first stage regressions. Instrument is the number of acquisitions (public targets acquired) conducted in the three-year period prior to IPO in the 2-digit SIC code industry of the IPO firm in the state of incorporation of IPO firm multiplied by the reciprocal of one plus the state-level non-compete agreement enforceability index. Tenure is the average number of years a firm's management tean members have been with the firm. TenHet is the coefficient of variation of management team members' tenures. LnAssets is the natural logarithm of the book value of assets immediately prior to IPO. LnAge is the natural logarithm of one plus firm age. OutDir is the proportion of outside directors in the board of directors. InsideOwn is the proportion of voting power owned by firm officers and directors immediately prior to IPO. CEO/Chair is an indicator variable equal to one if a CEO is also a Chairman of the board of directors, and zero otherwise. CapEx/Assets -1 is the ratio of capital expenditures over assets in fiscal year -1 prior to IPO. NI/Sales -1 is the ratio of net income to sales in fiscal year -1 prior to IPO. All regressions include 4-digit SIC industry code dummies and year dummies. $t$-statistics of first stage regressions and $z$-statistics of second stage regressions are in parentheses. $* * *, * *$, and * indicate significance at the 1,5 , and 10 percent levels, respectively.

\begin{tabular}{|c|c|c|c|c|c|c|c|c|}
\hline & (1) & (2) & (3) & (4) & (5) & $(6)$ & (7) & $(8)$ \\
\hline & $\begin{array}{l}\text { First stage } \\
\text { regression }\end{array}$ & $\begin{array}{l}\text { Second stage } \\
\text { regression }\end{array}$ & $\begin{array}{c}\begin{array}{c}\text { Second stage } \\
\text { regression }\end{array} \\
\end{array}$ & $\begin{array}{l}\text { Second stage } \\
\text { regression }\end{array}$ & $\begin{array}{c}\text { Second stage } \\
\text { regression }\end{array}$ & $\begin{array}{l}\text { First stage } \\
\text { regression }\end{array}$ & $\begin{array}{l}\text { Second stage } \\
\text { regression }\end{array}$ & $\begin{array}{l}\text { Second stage } \\
\text { regression }\end{array}$ \\
\hline Dependent variable & MQFactor & R\&D/Assets -1 & AveR\&D/Assets $-1 \&-2$ & LnR\&D -1 & LnAveR\&D -1 \& -2 & MQFactor & R\&D/Assets -2 & LnR\&D -2 \\
\hline Constant & $\begin{array}{l}-0.095 \\
(-0.08)\end{array}$ & $\begin{array}{c}1.738 \\
(4.43)^{* * *}\end{array}$ & $\begin{array}{c}1.911 \\
(4.20)^{* * *}\end{array}$ & $\begin{array}{c}16.052 \\
(2.08)^{* *}\end{array}$ & $\begin{array}{c}15.531 \\
(2.10)^{* *}\end{array}$ & $\begin{array}{l}2.366 \\
(1.41)\end{array}$ & $\begin{array}{l}2.239 \\
(1.46)\end{array}$ & $\begin{array}{l}9.017 \\
(0.65)\end{array}$ \\
\hline Instrument & $\begin{array}{c}0.005 \\
(3.19)^{* * *}\end{array}$ & & & & & $\begin{array}{l}0.003 \\
(1.45)\end{array}$ & & \\
\hline MQFHat & & $\begin{array}{c}0.182 \\
(1.70)^{*}\end{array}$ & $\begin{array}{c}0.268 \\
(2.16)^{* *}\end{array}$ & $\begin{array}{c}6.126 \\
(2.91)^{* * *}\end{array}$ & $\begin{array}{c}5.788 \\
(2.86)^{* * * *}\end{array}$ & & $\begin{array}{l}0.562 \\
(1.27)\end{array}$ & $\begin{array}{l}5.515 \\
(1.38)\end{array}$ \\
\hline Tenure & $\begin{array}{c}-0.051 \\
(-4.99)^{* * *}\end{array}$ & $\begin{array}{l}0.002 \\
(0.26)\end{array}$ & $\begin{array}{l}0.007 \\
(0.96)\end{array}$ & $\begin{array}{c}0.248 \\
(1.90)^{*}\end{array}$ & $\begin{array}{c}0.239 \\
(1.91)^{*}\end{array}$ & $\begin{array}{c}-0.038 \\
(-2.46)^{* *}\end{array}$ & $\begin{array}{l}0.018 \\
(0.90)\end{array}$ & $\begin{array}{l}0.232 \\
(1.30)\end{array}$ \\
\hline TenHet & $\begin{array}{c}0.053 \\
(1.76)^{*}\end{array}$ & $\begin{array}{l}-0.012 \\
(-0.98)\end{array}$ & $\begin{array}{l}-0.017 \\
(-1.26)\end{array}$ & $\begin{array}{l}-0.200 \\
(-0.87)\end{array}$ & $\begin{array}{l}-0.177 \\
(-0.80)\end{array}$ & $\begin{array}{c}0.265 \\
(1.69)^{*}\end{array}$ & $\begin{array}{l}-0.204 \\
(-1.34)\end{array}$ & $\begin{array}{l}-1.049 \\
(-0.76)\end{array}$ \\
\hline LnAssets & $\begin{array}{l}-0.032 \\
(-1.51)\end{array}$ & $\begin{array}{c}-0.089 \\
(-10.93)^{* * *}\end{array}$ & $\begin{array}{c}-0.095 \\
(-10.12)^{* * *}\end{array}$ & $\begin{array}{c}-0.691 \\
(-4.33)^{* * * *}\end{array}$ & $\begin{array}{c}-0.695 \\
(-4.53)^{* * *}\end{array}$ & $\begin{array}{l}0.031 \\
(0.85)\end{array}$ & $\begin{array}{c}-0.151 \\
(-5.59)^{* * *}\end{array}$ & $\begin{array}{c}-1.104 \\
(-4.50)^{* * *}\end{array}$ \\
\hline LnAge & $\begin{array}{l}0.081 \\
(1.88)^{*}\end{array}$ & $\begin{array}{l}-0.007 \\
(-0.40)\end{array}$ & $\begin{array}{l}-0.012 \\
(-0.65)\end{array}$ & $\begin{array}{l}-0.280 \\
(-0.87)\end{array}$ & $\begin{array}{l}-0.244 \\
(-0.79)\end{array}$ & $\begin{array}{l}-0.010 \\
(-0.14)\end{array}$ & $\begin{array}{l}0.011 \\
(0.23)\end{array}$ & $\begin{array}{c}0.800 \\
(1.85)^{*}\end{array}$ \\
\hline OutDir & $\begin{array}{l}-0.086 \\
(-0.62)\end{array}$ & $\begin{array}{l}0.071 \\
(1.47)\end{array}$ & $\begin{array}{l}0.088 \\
(1.56)\end{array}$ & $\begin{array}{c}2.551 \\
(2.68)^{* * *}\end{array}$ & $\begin{array}{c}2.450 \\
(2.68)^{* * *}\end{array}$ & $\begin{array}{l}-0.296 \\
(-1.24)\end{array}$ & $\begin{array}{l}0.242 \\
(1.22)\end{array}$ & $\begin{array}{c}3.732 \\
(2.07)^{* *}\end{array}$ \\
\hline InsideOwn & $\begin{array}{c}-0.248 \\
(-2.68)^{* * *}\end{array}$ & $\begin{array}{l}-0.024 \\
(-0.56)\end{array}$ & $\begin{array}{l}-0.010 \\
(-0.21)\end{array}$ & $\begin{array}{l}0.502 \\
(0.60)\end{array}$ & $\begin{array}{l}0.424 \\
(0.53)\end{array}$ & $\begin{array}{l}-0.209 \\
(-1.31)\end{array}$ & $\begin{array}{l}-0.016 \\
(-0.11)\end{array}$ & $\begin{array}{l}0.196 \\
(0.15)\end{array}$ \\
\hline CEO/Chair & $\begin{array}{l}-0.006 \\
(-0.13)\end{array}$ & $\begin{array}{c}-0.031 \\
(-1.94)^{*}\end{array}$ & $\begin{array}{l}-0.017 \\
(-0.94)\end{array}$ & $\begin{array}{l}-0.050 \\
(-0.16)\end{array}$ & $\begin{array}{l}-0.073 \\
(-0.24)\end{array}$ & $\begin{array}{l}-0.048 \\
(-0.64)\end{array}$ & $\begin{array}{c}0.094 \\
(1.77)^{*}\end{array}$ & $\begin{array}{l}0.167 \\
(0.35)\end{array}$ \\
\hline CapEx/Assets -1 & $\begin{array}{c}0.540 \\
(2.27)^{* *}\end{array}$ & $\begin{array}{c}0.348 \\
(3.52)^{* * *}\end{array}$ & $\begin{array}{l}0.151 \\
(1.31)\end{array}$ & $\begin{array}{c}-3.834 \\
(-1.97)^{* *}\end{array}$ & $\begin{array}{c}-3.735 \\
(-2.00)^{* *}\end{array}$ & $\begin{array}{c}0.657 \\
(1.68)^{*}\end{array}$ & $\begin{array}{c}-0.839 \\
(-2.17)^{* *}\end{array}$ & $\begin{array}{c}-9.027 \\
(-2.58)^{* * *}\end{array}$ \\
\hline NI/Sales -1 & $\begin{array}{l}-0.000 \\
(-1.29)\end{array}$ & $\begin{array}{l}-0.000 \\
(-1.47)\end{array}$ & $\begin{array}{l}-0.000 \\
(-1.09)\end{array}$ & $\begin{array}{c}0.002 \\
(0.78)\end{array}$ & $\begin{array}{l}0.002 \\
(0.73)\end{array}$ & $\begin{array}{l}-0.001 \\
(-1.53)\end{array}$ & $\begin{array}{l}0.000 \\
(0.08)\end{array}$ & $\begin{array}{l}0.005 \\
(0.90)\end{array}$ \\
\hline Industry Dummies & Yes & Yes & Yes & Yes & Yes & Yes & Yes & Yes \\
\hline Year Dummies & Yes & Yes & Yes & Yes & Yes & Yes & Yes & Yes \\
\hline $\mathrm{N}$ & 1,720 & 1,720 & 1,720 & 1,720 & 1,720 & 809 & 809 & 809 \\
\hline Centered $\mathrm{R}^{2}$ & 0.2527 & 0.2882 & 0.1189 & 0.3363 & 0.3663 & 0.3675 & -0.3399 & 0.4592 \\
\hline $\begin{array}{l}\text { F-statistic } \\
\text { (p-value) }\end{array}$ & $\begin{array}{c}10.18 \\
(0.0015)\end{array}$ & & & & & $\begin{array}{c}2.11 \\
(0.1469)\end{array}$ & & \\
\hline
\end{tabular}


Table 6. Instrumental variable analysis of the effect of management quality on the quantity and quality of pre-IPO innovation

The sample consists of 1,851 venture-backed IPOs conducted between 1993 and 2004. In first stage regressions, dependent variable MQFactor is the management quality factor score obtained using common factor analysis on the firm-size-, firm-age-, and industry-dummies-adjusted TSize, MBA, PriorExp, LawAcc, CPA, Core, CEODom, and Board. In second stage regressions, dependent variables LnCount - 1 and LnCount -2 are the natural logarithms of one plus the number of patents a firm files for (and is eventually granted) in years -1 and -2 , respectively, prior to IPO; LnCount $-1 \&$ - 2 is the natural logarithm of one plus the number of patents a firm files for (and is eventually granted) in years -1 and -2 combined prior to IPO, LnCite -1 and LnCite -2 are the natural logarithms of one plus the number of non-selfcitations per patent a firm files for (and is eventually granted) in years -1 and -2 , respectively, prior to IPO; and LnCite - 1 \& -2 is the natural logarithm of one plus the number of non-self-citations per patent a firm files for (and is eventually granted) in years -1 and -2 combined prior to IPO. MQFHat is the predicted value of MQFactor from the first stage regressions. Instrument is the number of acquisition (public targets acquired) conducted in the three-year period prior to IPO in the 2-digit SIC code industry of the IPO firm in the state of incorporation of IPO firm multiplied by the reciprocal of one plus the state-level non-compete agreement enforceability index. Tenure is the average number of years a firm's management team members have been with the firm. TenHet is the coefficient of variation of management team members' tenures. LnAssets is the natural logarithm of the book value of assets immediately prior to IPO. LnAge is the natural logarithm of one plus firm age. OutDir is the proportion of outside directors in the board of directors. InsideOwn is the proportion of voting power owned by firm officers and directors immediately prior to IPO CEO/Chair is an indicator variable equal to one if a CEO is also a Chairman of the board of directors, and zero otherwise. CapEx/Assets -1 is the ratio of capital expenditures over assets in fiscal year -1 prior to IPO. NI/Sales -1 is the ratio of net income to sales in fiscal year -1 prior to IPO. R\&D/Assets -1 is the ratio of R\&D expenses to assets in fiscal year -1 prior to IPO. All regressions include 4-digit SIC industry code dummies and year dummies. $t$ statistics of first stage regressions and $z$-statistics of second stage regressions are in parentheses. ${ }^{* * *}, * *$, and $*$ indicate significance at the 1,5 , and 10 percent levels, respectively

\begin{tabular}{|c|c|c|c|c|c|c|c|c|}
\hline & $(1)$ & $(2)$ & (3) & (4) & (5) & (6) & $(7)$ & (8) \\
\hline & $\begin{array}{l}\text { First stage } \\
\text { regression }\end{array}$ & $\begin{array}{l}\text { Second stage } \\
\text { regression }\end{array}$ & $\begin{array}{l}\text { Second stage } \\
\text { regression }\end{array}$ & $\begin{array}{l}\text { Second stage } \\
\text { regression }\end{array}$ & $\begin{array}{l}\text { Second stage } \\
\text { regression }\end{array}$ & $\begin{array}{l}\text { First stage } \\
\text { regression }\end{array}$ & $\begin{array}{l}\text { Second stage } \\
\text { regression }\end{array}$ & $\begin{array}{c}\text { Second stage } \\
\text { regression }\end{array}$ \\
\hline Dependent variable & MQFactor & LnCount -1 & LnCount $-1 \&-2$ & LnCite -1 & LnCite $-1 \&-2$ & MQFactor & LnCount -2 & LnCite -2 \\
\hline Constant & $\begin{array}{l}-0.369 \\
(-0.32)\end{array}$ & $\begin{array}{l}-0.402 \\
(-0.48)\end{array}$ & $\begin{array}{l}-0.454 \\
(-0.53)\end{array}$ & $\begin{array}{l}0.810 \\
(0.53)\end{array}$ & $\begin{array}{l}0.750 \\
(0.47)\end{array}$ & $\begin{array}{l}0.078 \\
(0.07)\end{array}$ & $\begin{array}{l}-0.353 \\
(-1.49)\end{array}$ & $\begin{array}{l}-0.508 \\
(-1.55)\end{array}$ \\
\hline Instrument & $\begin{array}{c}0.005 \\
(3.37)^{* * *}\end{array}$ & & & & & $\begin{array}{c}0.005 \\
(3.30)^{* * *}\end{array}$ & & \\
\hline MQFHat & & $\begin{array}{c}0.547 \\
(2.56)^{* *}\end{array}$ & $\begin{array}{c}0.581 \\
(2.61)^{* * * *}\end{array}$ & $\begin{array}{c}1.065 \\
(2.70)^{* * *}\end{array}$ & $\begin{array}{c}1.141 \\
(2.78)^{* * * *}\end{array}$ & & $\begin{array}{l}0.047 \\
(0.75)\end{array}$ & $\begin{array}{l}0.124 \\
(1.44)\end{array}$ \\
\hline Tenure & $\begin{array}{c}-0.051 \\
(-4.99)^{* * *}\end{array}$ & $\begin{array}{c}0.025 \\
(1.84)^{*}\end{array}$ & $\begin{array}{c}0.027 \\
(1.96)^{* *}\end{array}$ & $\begin{array}{c}0.059 \\
(2.37)^{* *}\end{array}$ & $\begin{array}{c}0.063 \\
(2.46)^{* *}\end{array}$ & $\begin{array}{c}-0.053 \\
(-4.95)^{* * *}\end{array}$ & $\begin{array}{l}0.001 \\
(0.34)\end{array}$ & $\begin{array}{l}0.007 \\
(1.32)\end{array}$ \\
\hline TenHet & $\begin{array}{c}0.054 \\
(1.81)^{*}\end{array}$ & $\begin{array}{l}-0.032 \\
(-1.33)\end{array}$ & $\begin{array}{l}-0.035 \\
(-1.37)\end{array}$ & $\begin{array}{l}-0.064 \\
(-1.42)\end{array}$ & $\begin{array}{l}-0.070 \\
(-1.49)\end{array}$ & $\begin{array}{c}0.050 \\
(1.67)^{*}\end{array}$ & $\begin{array}{l}-0.006 \\
(-0.82)\end{array}$ & $\begin{array}{l}-0.011 \\
(-1.11)\end{array}$ \\
\hline LnAssets & $\begin{array}{l}-0.019 \\
(-0.81)\end{array}$ & $\begin{array}{c}0.045 \\
(2.69)^{* * *}\end{array}$ & $\begin{array}{c}0.048 \\
(2.75)^{* * *}\end{array}$ & $\begin{array}{l}0.039 \\
(1.24)\end{array}$ & $\begin{array}{l}0.043 \\
(1.35)\end{array}$ & $\begin{array}{l}-0.005 \\
(-0.23)\end{array}$ & $\begin{array}{c}0.014 \\
(2.96)^{* * *}\end{array}$ & $\begin{array}{c}0.017 \\
(2.53)^{* *}\end{array}$ \\
\hline LnAge & $\begin{array}{l}0.070 \\
(1.59)\end{array}$ & $\begin{array}{l}-0.001 \\
(-0.04)\end{array}$ & $\begin{array}{l}-0.003 \\
(-0.07)\end{array}$ & $\begin{array}{l}-0.050 \\
(-0.80)\end{array}$ & $\begin{array}{l}-0.053 \\
(-0.81)\end{array}$ & $\begin{array}{l}0.055 \\
(1.14)\end{array}$ & $\begin{array}{l}0.014 \\
(1.41)\end{array}$ & $\begin{array}{l}0.012 \\
(0.87)\end{array}$ \\
\hline OutDir & $\begin{array}{l}-0.071 \\
(-0.51)\end{array}$ & $\begin{array}{l}-0.133 \\
(-1.31)\end{array}$ & $\begin{array}{l}-0.124 \\
(-1.18)\end{array}$ & $\begin{array}{l}-0.046 \\
(-0.25)\end{array}$ & $\begin{array}{l}-0.045 \\
(-0.23)\end{array}$ & $\begin{array}{l}-0.109 \\
(-0.77)\end{array}$ & $\begin{array}{l}-0.002 \\
(-0.07)\end{array}$ & $\begin{array}{l}-0.001 \\
(-0.01)\end{array}$ \\
\hline InsideOwn & $\begin{array}{c}-0.226 \\
(-2.44)^{* *}\end{array}$ & $\begin{array}{l}0.075 \\
(0.89)\end{array}$ & $\begin{array}{l}0.079 \\
(0.90)\end{array}$ & $\begin{array}{l}0.228 \\
(1.46)\end{array}$ & $\begin{array}{l}0.252 \\
(1.55)\end{array}$ & $\begin{array}{c}-0.229 \\
(-2.43)^{* *}\end{array}$ & $\begin{array}{l}-0.012 \\
(-0.49)\end{array}$ & $\begin{array}{l}0.025 \\
(0.73)\end{array}$ \\
\hline CEO/Chair & $\begin{array}{l}0.010 \\
(0.20)\end{array}$ & $\begin{array}{l}-0.052 \\
(-1.54)\end{array}$ & $\begin{array}{l}-0.054 \\
(-1.52)\end{array}$ & $\begin{array}{c}-0.131 \\
(-2.09)^{* *}\end{array}$ & $\begin{array}{c}-0.122 \\
(-1.88)^{*}\end{array}$ & $\begin{array}{l}0.018 \\
(0.37)\end{array}$ & $\begin{array}{l}-0.005 \\
(-0.50)\end{array}$ & $\begin{array}{l}0.001 \\
(0.04)\end{array}$ \\
\hline CapEx/Assets -1 & $\begin{array}{c}0.506 \\
(2.11)^{* *}\end{array}$ & $\begin{array}{l}-0.116 \\
(-0.58)\end{array}$ & $\begin{array}{l}-0.123 \\
(-0.59)\end{array}$ & $\begin{array}{l}-0.540 \\
(-1.45)\end{array}$ & $\begin{array}{l}-0.540 \\
(-1.40)\end{array}$ & $\begin{array}{c}0.555 \\
(2.23)^{* *}\end{array}$ & $\begin{array}{l}-0.013 \\
(-0.21)\end{array}$ & $\begin{array}{l}-0.043 \\
(-0.50)\end{array}$ \\
\hline NI/Sales -1 & $\begin{array}{c}-0.001 \\
(-2.00)^{* *}\end{array}$ & $\begin{array}{l}0.001 \\
(1.57)\end{array}$ & $\begin{array}{l}0.001 \\
(1.62)\end{array}$ & $\begin{array}{c}0.001 \\
(2.12)^{* *}\end{array}$ & $\begin{array}{c}0.001 \\
(2.14)^{* *}\end{array}$ & $\begin{array}{l}-0.001 \\
(-1.17)\end{array}$ & $\begin{array}{l}0.000 \\
(0.43)\end{array}$ & $\begin{array}{l}0.000 \\
(0.52)\end{array}$ \\
\hline $\mathrm{R} \& \mathrm{D} /$ Assets -1 & $\begin{array}{c}0.090 \\
(1.14)\end{array}$ & $\begin{array}{l}0.079 \\
(1.30)\end{array}$ & $\begin{array}{l}0.086 \\
(1.35)\end{array}$ & $\begin{array}{l}0.062 \\
(0.55)\end{array}$ & $\begin{array}{l}0.077 \\
(0.66)\end{array}$ & $\begin{array}{l}0.105 \\
(1.30)\end{array}$ & $\begin{array}{l}0.015 \\
(0.83)\end{array}$ & $\begin{array}{l}0.020 \\
(0.82)\end{array}$ \\
\hline Industry Dummies & Yes & Yes & Yes & Yes & Yes & Yes & Yes & Yes \\
\hline Year Dummies & Yes & Yes & Yes & Yes & Yes & Yes & Yes & Yes \\
\hline $\mathrm{N}$ & 1,706 & 1,706 & 1,706 & 1,706 & 1,706 & 1,661 & 1,661 & 1,661 \\
\hline Centered $\mathrm{R}^{2}$ & 0.2587 & -0.1926 & -0.2229 & -0.3082 & -0.3943 & 0.2582 & 0.2354 & 0.1540 \\
\hline F-statistic ( $p$-value) & $11.34(0.0008)$ & & & & & $10.88(0.0010)$ & & \\
\hline
\end{tabular}


Table 7. Relationship between management quality and pre-IPO innovation strategies and inventor quality

The sample consists of 1,851 venture-backed IPOs conducted between 1993 and 2004. ExplorRat is the fraction of explorative patents out of all the patents a firm files for (and is eventually granted) in the two-year period prior to its IPO. A patent is explorative if at least $80 \%$ of its citations do not refer to existing knowledge, which includes a firm's previous patent portfolio and all the patents that were cited by the firm's patents filed over the two-year period prior to its IPO. ExploitRat is the fraction of exploitative patents out of all the patents a firm files for (and is eventually granted) in the two-year period prior to its IPO. A patent is exploitative if at least $80 \%$ of its citations refer to existing knowledge, which includes a firm's previous patent portfolio and all the patents that were cited by the firm's patents filed over the two-year period prior to its IPO. LnNSelfCite is the natural logarithm of one plus the number of non-self-citations (i.e., the number of times that a firm cites patents owned by other firms) of all the patents cited by a firm's patents filed for (and eventually granted) in the two-year period prior to its IPO. LnSelfCite is the natural logarithm of one plus the number of self-citations of all the patents cited by a firm's patents filed for (and eventually granted) in the two-year period prior to its IPO. Diversity equals one minus the Herfindahl index of the number of patents filed by a firm (and eventually granted) over the two-year period prior to its IPO across 2-digit technological classes defined by the NBER patent database. InventorQual is the natural logarithm of one plus the number of inventors whose patents were filed by a firm in the two-year period prior to its IPO and who receive top $10 \%$ of the citations across various technological classes. MQFactor is the management quality factor score obtained using common factor analysis on the firm-size-, firm-age-, and industry-dummies-adjusted TSize, MBA, PriorExp, LawAcc, CPA, Core, CEODom, and Board. Tenure is the average number of years a firm's management team members have been with the firm. TenHet is the coefficient of variation of management team members' tenures. LnAssets is the natural logarithm of the book value of assets immediately prior to IPO. LnAge is the natural logarithm of one plus firm age. OutDir is the proportion of outside directors in the board of directors. InsideOwn is the proportion of voting power owned by firm officers and directors immediately prior to IPO. CEO/Chair is an indicator variable equal to one if a CEO is also a Chairman of the board of directors, and zero otherwise. CapEx/Assets -1 is the ratio of capital expenditures over assets in fiscal year -1 prior to IPO. NI/Sales -1 is the ratio of net income to sales in fiscal year -1 prior to IPO. $\mathrm{R} \& \mathrm{D} /$ Assets -1 is the ratio of R\&D expenses to assets in fiscal year -1 prior to IPO. All regressions include 4-digit SIC industry code dummies and year dummies. $t$-statistics are in parentheses. ${ }^{* *}, * *$, and $*$ indicate significance at the 1,5 , and 10 percent levels, respectively.

\begin{tabular}{|c|c|c|c|c|c|c|}
\hline & (1) & (2) & (3) & (4) & (5) & (6) \\
\hline Dependent variable & ExplorRat & ExploitRat & LnNSelfCite & LnSelfCite & Diversity & InventorQual \\
\hline \multirow[t]{2}{*}{ Constant } & 0.016 & -0.036 & -1.924 & -0.170 & -0.255 & -2.251 \\
\hline & $(0.03)$ & $(-0.37)$ & $(-0.95)$ & $(-0.32)$ & $(-1.02)$ & $(-2.01)^{* *}$ \\
\hline \multirow[t]{2}{*}{ MQFactor } & 0.031 & 0.003 & 0.189 & 0.013 & 0.015 & 0.052 \\
\hline & $(2.51)^{* *}$ & $(1.15)$ & $(3.78)^{* * *}$ & $(0.97)$ & $(2.46)^{* *}$ & $(1.87)^{*}$ \\
\hline \multirow[t]{2}{*}{ Tenure } & 0.001 & -0.000 & 0.006 & 0.001 & -0.003 & -0.003 \\
\hline & $(0.14)$ & $(-0.05)$ & $(0.33)$ & $(0.25)$ & $(-1.18)$ & $(-0.26)$ \\
\hline \multirow[t]{2}{*}{ TenHet } & -0.001 & 0.001 & 0.041 & 0.005 & 0.002 & 0.017 \\
\hline & $(-0.09)$ & $(0.40)$ & $(0.73)$ & $(0.34)$ & $(0.25)$ & $(0.57)$ \\
\hline \multirow[t]{2}{*}{ LnAssets } & 0.015 & 0.001 & 0.153 & 0.018 & 0.025 & 0.095 \\
\hline & $(1.41)$ & $(0.51)$ & $(3.56)^{* * *}$ & (1.64) & $(4.68)^{* * *}$ & $(4.01)^{* * *}$ \\
\hline \multirow[t]{2}{*}{ LnAge } & -0.014 & -0.002 & -0.157 & -0.023 & -0.003 & -0.039 \\
\hline & $(-0.70)$ & $(-0.58)$ & $(-1.89)^{*}$ & $(-1.05)$ & $(-0.24)$ & $(-0.84)$ \\
\hline \multirow[t]{2}{*}{ OutDir } & 0.000 & 0.015 & -0.203 & -0.073 & -0.021 & 0.089 \\
\hline & $(0.01)$ & $(1.16)$ & $(-0.77)$ & $(-1.07)$ & $(-0.64)$ & $(0.62)$ \\
\hline \multirow[t]{2}{*}{ InsideOwn } & -0.022 & 0.000 & -0.114 & -0.035 & -0.036 & -0.154 \\
\hline & $(-0.51)$ & $(0.04)$ & $(-0.65)$ & $(-0.78)$ & $(-1.65)^{*}$ & $(-1.59)$ \\
\hline \multirow[t]{2}{*}{ CEO/Chair } & -0.049 & -0.002 & -0.136 & -0.031 & -0.014 & -0.059 \\
\hline & $(-2.26)^{* *}$ & $(-0.50)$ & $(-1.53)$ & $(-1.36)$ & $(-1.26)$ & $(-1.20)$ \\
\hline \multirow[t]{2}{*}{ CapEx/Assets -1 } & 0.128 & 0.021 & 0.525 & -0.004 & 0.005 & 0.345 \\
\hline & $(1.16)$ & $(0.97)$ & $(1.16)$ & $(-0.03)$ & $(0.09)$ & $(1.38)$ \\
\hline \multirow[t]{2}{*}{ NI/Sales -1 } & 0.000 & -0.000 & 0.000 & 0.000 & 0.000 & 0.001 \\
\hline & $(0.63)$ & $(-1.01)$ & $(0.41)$ & $(0.62)$ & $(0.53)$ & $(1.22)$ \\
\hline \multirow[t]{2}{*}{ R\&D/Assets -1 } & 0.097 & 0.002 & 0.574 & 0.043 & 0.089 & 0.294 \\
\hline & $(2.67)^{* * *}$ & $(0.35)$ & $(3.86)^{* * *}$ & (1.13) & $(4.80)^{* * *}$ & $(3.58)^{* * *}$ \\
\hline Industry Dummies & Yes & Yes & Yes & Yes & Yes & Yes \\
\hline Year Dummies & Yes & Yes & Yes & Yes & Yes & Yes \\
\hline $\mathrm{N}$ & 1,706 & 1,706 & 1,706 & 1,706 & 1,706 & 1,706 \\
\hline \multirow[t]{3}{*}{$\mathrm{R}^{2}$} & 0.3168 & 0.1406 & 0.3954 & 0.2541 & 0.3415 & 0.2596 \\
\hline & $\begin{array}{r}\text { Difference bety } \\
\text { MQFactor in } 1 \\
\text { with } \chi^{2} \text {-stat }\end{array}$ & $\begin{array}{l}\text { coefficients of } \\
\text { ons (1) and ( } 2) \\
\text { parentheses }\end{array}$ & \multirow{2}{*}{\multicolumn{2}{|c|}{$\begin{array}{l}\text { Difference between the coefficients } \\
\text { of MQFactor in regressions ( } 3 \text { ) and } \\
\text { (4) with } \chi^{2} \text {-statistic in parentheses } \\
0.177(16.70)^{* * *}\end{array}$}} & & \\
\hline & 0.0 & ** & & & & \\
\hline
\end{tabular}


Table 8. Instrumental variable analysis of the effect of management quality on pre-IPO innovation strategies and inventor quality The sample consists of 1,851 venture-backed IPOs conducted between 1993 and 2004. In first stage regression, dependent variable MQFactor is the management quality factor score obtained using common factor analysis on the firm-size-, firm-age-, and industry-dummies-adjusted TSize, MBA, PriorExp, LawAcc, CPA, Core, CEODom, and Board. In second stage regressions, dependent variables are as follows. ExplorRat is the fraction of explorative patents out of all the patents a firm files for (and is eventually granted) in the two-year period prior to its IPO. A patent is explorative if at least $80 \%$ of its citations do not refer to existing knowledge, which includes a firm's previous patent portfolio and all the patents that were cited by the firm's patents filed over the two-year period prior to its IPO. ExploitRat is the fraction of exploitative patents out of all the patents a firm files for (and is eventually granted) in the two-year period prior to its IPO. A patent is exploitative if at least $80 \%$ of its citations refer to existing knowledge, which includes a firm's previous patent portfolio and all the patents that were cited by the firm's patents filed over the two-year period prior to its IPO. LnNSelfCite is the natural logarithm of one plus the number of non-self-citations (i.e., the number of times that a firm cites patents owned by other firms) of all the patents cited by a firm's patents filed for (and eventually granted) in the two-year period prior to its IPO. LnSelfCite is the natural logarithm of one plus the number of self-citations of all the patents cited by a firm's patents filed for (and eventually granted) in the two-year period prior to its IPO. Diversity equals one minus the Herfindahl index of the number of patents filed by a firm (and eventually granted) over the two-year period prior to its IPO across 2-digit technological classes defined by the NBER patent database. InventorQual is the natural logarithm of one plus the number of inventors whose patents were filed by a firm in the two-year period prior to its IPO and who receive top $10 \%$ of the citations across various technological classes. MQFHat is the predicted value of MQFactor from the first stage regressions. Instrument is the number of acquisitions (public targets acquired) conducted in the three-year period prior to IPO in the 2-digit SIC code industry of the IPO firm in the state of incorporation of IPO firm multiplied by the reciprocal of one plus the state-level noncompete agreement enforceability index. Tenure is the average number of years a firm's management team members have been with the firm. TenHet is the coefficient of variation of management team members' tenures. LnAssets is the natural logarithm of the book value of assets immediately prior to IPO. LnAge is the natural logarithm of one plus firm age. OutDir is the proportion of outside directors in the board of directors. InsideOwn is the proportion of voting power owned by firm officers and directors immediately prior to IPO. CEO/Chair is an indicator variable equal to one if a CEO is also a Chairman of the board of directors, and zero otherwise. CapEx/Assets -1 is the ratio of capital expenditures over assets in fiscal year -1 prior to IPO. NI/Sales -1 is the ratio of net income to sales in fiscal year -1 prior to IPO. R\&D/Assets -1 is the ratio of R\&D expenses to assets in fiscal year -1 prior to IPO. All regressions include 4-digit SIC industry code dummies and year dummies. $t$-statistics of first stage regression and $z$-statistics of second stage regressions are in parentheses. $* * *, * *$, and $*$ indicate significance at the 1,5 , and 10 percent levels, respectively.

\begin{tabular}{|c|c|c|c|c|c|c|c|}
\hline & (1) & $(2)$ & (3) & (4) & (5) & $(6)$ & (7) \\
\hline & $\begin{array}{l}\text { First stage } \\
\text { regression }\end{array}$ & $\begin{array}{l}\text { Second stage } \\
\text { regression }\end{array}$ & $\begin{array}{l}\text { Second stage } \\
\text { regression }\end{array}$ & $\begin{array}{l}\text { Second stage } \\
\text { regression }\end{array}$ & $\begin{array}{c}\text { Second stage } \\
\text { regression }\end{array}$ & $\begin{array}{l}\text { Second stage } \\
\text { regression }\end{array}$ & $\begin{array}{c}\text { Second stage } \\
\text { regression }\end{array}$ \\
\hline Dependent variable & MQFactor & ExplorRat & ExploitRat & LnNSelfCite & LnSelfCite & Diversity & InventorQual \\
\hline Constant & $\begin{array}{l}-0.369 \\
(-0.32)\end{array}$ & $\begin{array}{l}0.237 \\
(0.34)\end{array}$ & $\begin{array}{l}-0.056 \\
(-0.59)\end{array}$ & $\begin{array}{l}-1.351 \\
(-0.42)\end{array}$ & $\begin{array}{l}-0.138 \\
(-0.24)\end{array}$ & $\begin{array}{l}-0.191 \\
(-0.53)\end{array}$ & $\begin{array}{l}-2.062 \\
(-1.37)\end{array}$ \\
\hline Instrument & $\begin{array}{c}0.005 \\
(3.37)^{* * *}\end{array}$ & & & & & & \\
\hline MQFHat & & $\begin{array}{c}0.507 \\
(2.83)^{* * *}\end{array}$ & $\begin{array}{l}-0.010 \\
(-0.42)\end{array}$ & $\begin{array}{c}2.560 \\
(3.12)^{* * *}\end{array}$ & $\begin{array}{c}0.259 \\
(1.76)^{*}\end{array}$ & $\begin{array}{c}0.264 \\
(2.86)^{* * *}\end{array}$ & $\begin{array}{c}1.034 \\
(2.67)^{* * *}\end{array}$ \\
\hline Tenure & $\begin{array}{c}-0.051 \\
(-4.99)^{* * *}\end{array}$ & $\begin{array}{c}0.026 \\
(2.28)^{* *}\end{array}$ & $\begin{array}{l}-0.001 \\
(-0.47)\end{array}$ & $\begin{array}{c}0.131 \\
(2.54)^{* *}\end{array}$ & $\begin{array}{l}0.014 \\
(1.53)\end{array}$ & $\begin{array}{c}0.010 \\
(1.75)^{*}\end{array}$ & $\begin{array}{c}0.049 \\
(2.00)^{* *}\end{array}$ \\
\hline TenHet & $\begin{array}{c}0.054 \\
(1.81)^{*}\end{array}$ & $\begin{array}{l}-0.028 \\
(-1.35)\end{array}$ & $\begin{array}{l}0.002 \\
(0.64)\end{array}$ & $\begin{array}{l}-0.091 \\
(-0.97)\end{array}$ & $\begin{array}{l}-0.009 \\
(-0.52)\end{array}$ & $\begin{array}{l}-0.012 \\
(-1.14)\end{array}$ & $\begin{array}{l}-0.037 \\
(-0.84)\end{array}$ \\
\hline LnAssets & $\begin{array}{l}-0.019 \\
(-0.81)\end{array}$ & $\begin{array}{l}0.023 \\
(1.62)\end{array}$ & $\begin{array}{l}0.001 \\
(0.43)\end{array}$ & $\begin{array}{c}0.193 \\
(3.00)^{* * *}\end{array}$ & $\begin{array}{c}0.022 \\
(1.93)^{*}\end{array}$ & $\begin{array}{c}0.029 \\
(4.02)^{* * *}\end{array}$ & $\begin{array}{c}0.112 \\
(3.67)^{* * *}\end{array}$ \\
\hline LnAge & $\begin{array}{l}0.070 \\
(1.59)\end{array}$ & $\begin{array}{l}-0.042 \\
(-1.46)\end{array}$ & $\begin{array}{l}-0.002 \\
(-0.39)\end{array}$ & $\begin{array}{c}-0.295 \\
(-2.25)^{* *}\end{array}$ & $\begin{array}{l}-0.037 \\
(-1.57)\end{array}$ & $\begin{array}{l}-0.017 \\
(-1.15)\end{array}$ & $\begin{array}{l}-0.096 \\
(-1.55)\end{array}$ \\
\hline OutDir & $\begin{array}{l}-0.071 \\
(-0.51)\end{array}$ & $\begin{array}{l}0.032 \\
(0.37)\end{array}$ & $\begin{array}{l}0.014 \\
(1.18)\end{array}$ & $\begin{array}{l}-0.049 \\
(-0.13)\end{array}$ & $\begin{array}{l}-0.057 \\
(-0.81)\end{array}$ & $\begin{array}{l}-0.005 \\
(-0.11)\end{array}$ & $\begin{array}{l}0.153 \\
(0.84)\end{array}$ \\
\hline InsideOwn & $\begin{array}{c}-0.226 \\
(-2.44)^{* *}\end{array}$ & $\begin{array}{l}0.094 \\
(1.33)\end{array}$ & $\begin{array}{l}-0.003 \\
(-0.30)\end{array}$ & $\begin{array}{l}0.464 \\
(1.43)\end{array}$ & $\begin{array}{l}0.025 \\
(0.43)\end{array}$ & $\begin{array}{l}0.025 \\
(0.67)\end{array}$ & $\begin{array}{l}0.085 \\
(0.56)\end{array}$ \\
\hline CEO/Chair & $\begin{array}{l}0.010 \\
(0.20)\end{array}$ & $\begin{array}{c}-0.052 \\
(-1.84)^{*}\end{array}$ & $\begin{array}{l}-0.002 \\
(-0.52)\end{array}$ & $\begin{array}{l}-0.153 \\
(-1.18)\end{array}$ & $\begin{array}{l}-0.033 \\
(-1.41)\end{array}$ & $\begin{array}{l}-0.016 \\
(-1.07)\end{array}$ & $\begin{array}{l}-0.066 \\
(-1.08)\end{array}$ \\
\hline Capex/Assets -1 & $\begin{array}{c}0.506 \\
(2.11)^{* *}\end{array}$ & $\begin{array}{l}-0.101 \\
(-0.60)\end{array}$ & $\begin{array}{l}0.027 \\
(1.18)\end{array}$ & $\begin{array}{l}-0.616 \\
(-0.80)\end{array}$ & $\begin{array}{l}-0.122 \\
(-0.88)\end{array}$ & $\begin{array}{l}-0.115 \\
(-1.32)\end{array}$ & $\begin{array}{l}-0.128 \\
(-0.35)\end{array}$ \\
\hline NI/Sales -1 & $\begin{array}{c}-0.001 \\
(-2.00)^{* *}\end{array}$ & $\begin{array}{c}0.001 \\
(1.76)^{*}\end{array}$ & $\begin{array}{l}-0.000 \\
(-1.22)\end{array}$ & $\begin{array}{c}0.002 \\
(1.70)^{*}\end{array}$ & $\begin{array}{l}0.000 \\
(1.37)\end{array}$ & $\begin{array}{c}0.000 \\
(1.70)^{*}\end{array}$ & $\begin{array}{c}0.001 \\
(2.12)^{* *}\end{array}$ \\
\hline $\mathrm{R} \& \mathrm{D} /$ Assets -1 & $\begin{array}{c}0.090 \\
(1.14)\end{array}$ & $\begin{array}{l}0.047 \\
(0.93)\end{array}$ & $\begin{array}{l}0.004 \\
(0.55)\end{array}$ & $\begin{array}{l}0.329 \\
(1.41)\end{array}$ & $\begin{array}{l}0.018 \\
(0.43)\end{array}$ & $\begin{array}{c}0.063 \\
(2.40)^{* *}\end{array}$ & $\begin{array}{c}0.192 \\
(1.75)^{*}\end{array}$ \\
\hline Industry Dummies & Yes & Yes & Yes & Yes & Yes & Yes & Yes \\
\hline Year Dummies & Yes & Yes & Yes & Yes & Yes & Yes & Yes \\
\hline $\mathrm{N}$ & 1,706 & 1,706 & 1,706 & 1,706 & 1,706 & 1,706 & 1,706 \\
\hline Centered $\mathrm{R}^{2}$ & 0.2587 & -0.4221 & 0.1224 & -0.5666 & 0.0609 & -0.4070 & -0.4050 \\
\hline
\end{tabular}


Table 9. Relationship between pre-IPO innovation, management quality, and IPO firm valuation

The sample consists of 1,851 venture-backed IPOs conducted between 1993 and 2004. QOP, QFTD, and QIM are three definitions of Tobin's Q. Tobin's Q is the ratio of the market value of assets to the book value of assets, where the market value of assets is equal to the book value of assets minus the book value of common equity plus the number of shares outstanding times the market price (either IPO offer price (for QOP), first trading day closing price (for QFTD), or the closing price at the end of the issue month (for QIM)). LnAssets is the natural logarithm of the book value of assets immediately prior to IPO. LnAge is the natural logarithm of one plus firm age. OutDir is the proportion of outside directors in the board of directors. InsideOwn is the proportion of voting power owned by firm officers and directors immediately prior to IPO. CEO/Chair is an indicator variable equal to one if a CEO is also a Chairman of the board of directors, and zero otherwise. CapEx/Assets -1 is the ratio of capital expenditures over assets in fiscal year -1 prior to IPO. NI/Sales -1 is the ratio of net income to sales in fiscal year -1 prior to IPO. All regressions include 4-digit SIC industry code dummies and year dummies. Dependent variables are winsorized at the $99^{\text {th }}$ percentile. $t$-statistics are in parentheses. ${ }^{* *},{ }^{* *}$, and $*$ indicate significance at the 1,5 , and 10 percent levels, respectively.

Panel A. Relationship between pre-IPO innovation and firm valuation at IPO and in the immediate post-IPO secondary market

LnCount $-1 \&-2$ is the natural logarithm of one plus the number of patents a firm files for (and is eventually granted) in years -1 and -2 combined prior to IPO. LnCite $-1 \&-2$ is the natural logarithm of one plus the number of non-self-citations per patent a firm files for (and is eventually granted) in years -1 and -2 combined prior to IPO.

\begin{tabular}{|c|c|c|c|c|c|c|}
\hline & $(1)$ & $(2)$ & (3) & (4) & (5) & (6) \\
\hline & QOP & QFTD & QIM & QOP & QFTD & QIM \\
\hline Constant & $\begin{array}{c}4.342 \\
(2.43)^{* *}\end{array}$ & $\begin{array}{l}6.276 \\
(138)\end{array}$ & $\begin{array}{l}4.085 \\
(090)\end{array}$ & $\begin{array}{c}4.257 \\
(2.38) * *\end{array}$ & $\begin{array}{l}6.130 \\
(135)\end{array}$ & $\begin{array}{l}3.810 \\
(0.84)\end{array}$ \\
\hline LnCount -1 \& -2 & $\begin{array}{c}0.129 \\
(1.78)^{*}\end{array}$ & $\begin{array}{l}0.219 \\
(1.19)\end{array}$ & $\begin{array}{c}0.414 \\
(2.22)^{* *}\end{array}$ & & & \\
\hline LnCite $-1 \&-2$ & & & & $\begin{array}{c}0.078 \\
(1.90)^{*}\end{array}$ & $\begin{array}{c}0.177 \\
(1.69)^{*}\end{array}$ & $\begin{array}{c}0.265 \\
(2.50)^{* *}\end{array}$ \\
\hline LnAssets & $\begin{array}{c}-0.216 \\
(-5.89)^{* * * *}\end{array}$ & $\begin{array}{c}-0.288 \\
(-3.10)^{* * *}\end{array}$ & $\begin{array}{c}-0.269 \\
(-2.85) * * *\end{array}$ & $\begin{array}{c}-0.214 \\
(-5.82)^{* * *}\end{array}$ & $\begin{array}{c}-0.284 \\
(-3.05)^{* * *}\end{array}$ & $\begin{array}{c}-0.260 \\
(-2.77)^{* * *}\end{array}$ \\
\hline LnAge & $\begin{array}{c}-0.213 \\
(-3.29) * * *\end{array}$ & $\begin{array}{c}-0.653 \\
(-3.95)^{* * *}\end{array}$ & $\begin{array}{c}-0.467 \\
(-2.80)^{* * *}\end{array}$ & $\begin{array}{c}-0.212 \\
(-3.26)^{* * *}\end{array}$ & $\begin{array}{c}-0.651 \\
(-3.94)^{* * *}\end{array}$ & $\begin{array}{c}-0.461 \\
(-2.76)^{* * *}\end{array}$ \\
\hline OutDir & $\begin{array}{l}-0.008 \\
(-0.03)\end{array}$ & $\begin{array}{l}0.016 \\
(0.03)\end{array}$ & $\begin{array}{l}0.611 \\
(1.01)\end{array}$ & $\begin{array}{l}-0.021 \\
(-0.09)\end{array}$ & $\begin{array}{l}-0.001 \\
(-0.00)\end{array}$ & $\begin{array}{l}0.575 \\
(0.95)\end{array}$ \\
\hline InsideOwn & $\begin{array}{c}0.541 \\
(3.44)^{* * *}\end{array}$ & $\begin{array}{c}0.932 \\
(2.34)^{* *}\end{array}$ & $\begin{array}{c}0.783 \\
(1.95)^{*}\end{array}$ & $\begin{array}{c}0.534 \\
(3.40)^{* * *}\end{array}$ & $\begin{array}{c}0.919 \\
(2.31)^{* *}\end{array}$ & $\begin{array}{c}0.760 \\
(1.90)^{*}\end{array}$ \\
\hline CEO/Chair & $\begin{array}{l}0.053 \\
(0.67)\end{array}$ & $\begin{array}{l}-0.211 \\
(-1.04)\end{array}$ & $\begin{array}{l}-0.159 \\
(-0.77)\end{array}$ & $\begin{array}{l}0.055 \\
(0.69)\end{array}$ & $\begin{array}{l}-0.203 \\
(-0.99)\end{array}$ & $\begin{array}{l}-0.152 \\
(-0.74)\end{array}$ \\
\hline CapEx/Assets -1 & $\begin{array}{l}0.088 \\
(0.22)\end{array}$ & $\begin{array}{l}0.486 \\
(0.48)\end{array}$ & $\begin{array}{c}1.704 \\
(1.65)^{*}\end{array}$ & $\begin{array}{l}0.109 \\
(0.27)\end{array}$ & $\begin{array}{l}0.519 \\
(0.51)\end{array}$ & $\begin{array}{c}1.764 \\
(1.71)^{*}\end{array}$ \\
\hline NI/Sales -1 & $\begin{array}{l}-0.000 \\
(-0.12)\end{array}$ & $\begin{array}{l}0.002 \\
(0.98)\end{array}$ & $\begin{array}{l}0.002 \\
(1.30)\end{array}$ & $\begin{array}{l}-0.000 \\
(-0.15)\end{array}$ & $\begin{array}{l}0.002 \\
(0.94)\end{array}$ & $\begin{array}{l}0.002 \\
(1.26)\end{array}$ \\
\hline Industry Dummies & Yes & Yes & Yes & Yes & Yes & Yes \\
\hline Year Dummies & Yes & Yes & Yes & Yes & Yes & Yes \\
\hline $\mathrm{N}$ & 1,651 & 1,653 & 1,610 & 1,651 & 1,653 & 1,610 \\
\hline $\mathrm{R}^{2}$ & 0.3913 & 0.3523 & 0.3611 & 0.3915 & 0.3530 & 0.3617 \\
\hline
\end{tabular}


Table 9 (continued)

Panel B. Relationship between pre-IPO innovation, management quality, and firm valuation at IPO and in the immediate post-IPO secondary market

Q1Count is a dummy variable which takes a value of one for firms with above median number of patents a firm files for (and is eventually granted) in years -1 and -2 combined prior to IPO and above median MQFactor, and zero otherwise. Q1Cite is a dummy variable which takes a value of one for firms with above median number of non-self-citations per patent a firm files for (and is eventually granted) in years -1 and -2 combined prior to IPO and above median MQFactor, and zero otherwise. MQFactor is the management quality factor score obtained using common factor analysis on the firm-size-, firm-age-, and industry-dummies-adjusted TSize, MBA, PriorExp, LawAcc, CPA, Core, CEODom, and Board. Tenure is the average number of years a firm's management team members have been with the firm. TenHet is the coefficient of variation of management team members' tenures.

\begin{tabular}{|c|c|c|c|c|c|c|}
\hline & (1) & (2) & (3) & (4) & (5) & (6) \\
\hline & QOP & QFTD & QIM & QOP & QFTD & QIM \\
\hline \multirow[t]{2}{*}{ Constant } & 4.324 & 6.261 & 3.990 & 4.321 & 6.255 & 3.981 \\
\hline & $(2.42)^{* *}$ & $(1.38)$ & $(0.88)$ & $(2.42)^{* *}$ & (1.38) & $(0.88)$ \\
\hline \multirow[t]{2}{*}{ Q1Count } & 0.319 & 0.642 & 1.001 & & & \\
\hline & $(2.23)^{* *}$ & $(1.74)^{*}$ & $(2.68)^{* * *}$ & & & \\
\hline \multirow[t]{2}{*}{ Q1Cite } & & & & 0.318 & 0.638 & 0.997 \\
\hline & & & & $(2.21)^{* *}$ & $(1.73)^{*}$ & $(2.66)^{* * *}$ \\
\hline \multirow[t]{2}{*}{ Tenure } & -0.035 & -0.074 & -0.055 & -0.035 & -0.074 & -0.054 \\
\hline & $(-2.02)^{* *}$ & $(-1.67)^{*}$ & $(-1.21)$ & $(-2.01)^{* *}$ & $(-1.66)^{*}$ & $(-1.19)$ \\
\hline \multirow[t]{2}{*}{ TenHet } & 0.058 & 0.036 & 0.018 & 0.058 & 0.036 & 0.018 \\
\hline & $(1.16)$ & $(0.28)$ & $(0.14)$ & $(1.16)$ & $(0.28)$ & $(0.14)$ \\
\hline \multirow[t]{2}{*}{ LnAssets } & -0.212 & -0.281 & -0.257 & -0.212 & -0.281 & -0.256 \\
\hline & $(-5.80) * * *$ & $(-3.03) * * *$ & $(-2.73)^{* * *}$ & $(-5.79) * * *$ & $(-3.03) * * *$ & $(-2.72)^{* * *}$ \\
\hline \multirow[t]{2}{*}{ LnAge } & -0.156 & -0.504 & -0.348 & -0.156 & -0.504 & -0.348 \\
\hline & $(-2.05)^{* *}$ & $(-2.61) * * *$ & $(-1.78)^{*}$ & $(-2.06)^{* *}$ & $(-2.62)^{* * *}$ & $(-1.78)^{*}$ \\
\hline \multirow[t]{2}{*}{ OutDir } & -0.036 & -0.067 & 0.521 & -0.035 & -0.067 & 0.521 \\
\hline & $(-0.15)$ & $(-0.11)$ & $(0.86)$ & $(-0.15)$ & $(-0.11)$ & $(0.86)$ \\
\hline \multirow[t]{2}{*}{ InsideOwn } & 0.544 & 0.954 & 0.783 & 0.543 & 0.952 & 0.780 \\
\hline & $(3.45)^{* * *}$ & $(2.39)^{* *}$ & $(1.95)^{*}$ & $(3.45)^{* * *}$ & $(2.39) * *$ & $(1.94)^{*}$ \\
\hline \multirow[t]{2}{*}{ CEO/Chair } & 0.061 & -0.189 & -0.138 & 0.061 & -0.190 & -0.140 \\
\hline & $(0.76)$ & $(-0.93)$ & $(-0.67)$ & $(0.76)$ & $(-0.93)$ & $(-0.68)$ \\
\hline \multirow[t]{2}{*}{ CapEx/Assets -1 } & 0.071 & 0.460 & 1.732 & 0.071 & 0.460 & 1.732 \\
\hline & $(0.18)$ & $(0.45)$ & $(1.67)^{*}$ & $(0.18)$ & $(0.45)$ & $(1.67)^{*}$ \\
\hline \multirow[t]{2}{*}{ NI/Sales -1 } & -0.000 & 0.002 & 0.002 & -0.000 & 0.002 & 0.002 \\
\hline & $(-0.13)$ & $(0.96)$ & $(1.31)$ & $(-0.13)$ & $(0.96)$ & $(1.31)$ \\
\hline Industry Dummies & Yes & Yes & Yes & Yes & Yes & Yes \\
\hline Year Dummies & Yes & Yes & Yes & Yes & Yes & Yes \\
\hline $\mathrm{N}$ & 1,651 & 1,653 & 1,610 & 1,651 & 1,653 & 1,610 \\
\hline $\mathrm{R}^{2}$ & 0.3944 & 0.3545 & 0.3629 & 0.3944 & 0.3545 & 0.3629 \\
\hline
\end{tabular}


Table 10. Relationship between pre-IPO innovation, management quality, and firm age at IPO

The sample consists of 1,851 venture-backed IPOs conducted between 1993 and 2004. Dependent variable in all regressions is the number of years from firm founding year to IPO year. LnCount $-1 \&-2$ is the natural logarithm of one plus the number of patents a firm files for (and is eventually granted) in years -1 and -2 combined prior to IPO. LnCite $-1 \&-2$ is the natural logarithm of one plus the number of non-self-citations per patent a firm files for (and is eventually granted) in years -1 and -2 combined prior to IPO. Q1Count is a dummy variable which takes a value of one for firms with above median number of patents a firm files for (and is eventually granted) in years -1 and -2 combined prior to IPO and above median MQFactor, and zero otherwise. Q1Cite is a dummy variable which takes a value of one for firms with above median number of non-self-citations per patent a firm files for (and is eventually granted) in years -1 and -2 combined prior to IPO and above median MQFactor, and zero otherwise. MQFactor is the management quality factor score obtained using common factor analysis on the firm-size-, firm-age-, and industry-dummies-adjusted TSize, MBA, PriorExp, LawAcc, CPA, Core, CEODom, and Board. LnAssets is the natural logarithm of the book value of assets immediately prior to IPO. OutDir is the proportion of outside directors in the board of directors. InsideOwn is the proportion of voting power owned by firm officers and directors immediately prior to IPO. CEO/Chair is an indicator variable equal to one if a CEO is also a Chairman of the board of directors, and zero otherwise. CapEx/Assets -1 is the ratio of capital expenditures over assets in fiscal year -1 prior to IPO. NI/Sales -1 is the ratio of net income to sales in fiscal year -1 prior to IPO. All regressions include 4-digit SIC industry code dummies. Specifications (1), (3), (5), and (7) are maximum-likelihood estimations for proportional hazard survival-time models with Gompertz survival distribution. Specifications (2), (4), (6), and (8) are maximum-likelihood estimations for proportional hazard survival-time models with Weibull survival distribution. Standard errors are clustered at year level. $z$-statistics are in parentheses. ${ }^{* *},{ }^{* *}$, and ${ }^{*}$ indicate significance at the 1,5 , and 10 percent levels, respectively.

\begin{tabular}{|c|c|c|c|c|c|c|c|c|}
\hline & $(1)$ & $(2)$ & (3) & (4) & $(5)$ & $(6)$ & $(7)$ & $(8)$ \\
\hline Constant & $\begin{array}{l}-0.306 \\
(-0.80)\end{array}$ & $\begin{array}{c}-1.047 \\
(-1.69) *\end{array}$ & $\begin{array}{l}-0.341 \\
(-0.91)\end{array}$ & $\begin{array}{c}-1.110 \\
(-1.83)^{*}\end{array}$ & $\begin{array}{l}-0.146 \\
(-0.51)\end{array}$ & $\begin{array}{l}-0.524 \\
(-0.92)\end{array}$ & $\begin{array}{l}-0.150 \\
(-0.52)\end{array}$ & $\begin{array}{l}-0.529 \\
(-0.93)\end{array}$ \\
\hline LnCount $-1 \&-2$ & $\begin{array}{c}0.073 \\
(1.70)^{*}\end{array}$ & $\begin{array}{l}0.103 \\
(1.53)\end{array}$ & & & & & & \\
\hline LnCite $-1 \&-2$ & & & $\begin{array}{c}0.060 \\
(2.57)^{* *}\end{array}$ & $\begin{array}{c}0.088 \\
(2.25)^{* *}\end{array}$ & & & & \\
\hline Q1Count & & & & & $\begin{array}{c}0.127 \\
(2.43)^{* *}\end{array}$ & $\begin{array}{c}0.221 \\
(2.13)^{* *}\end{array}$ & & \\
\hline Q1Cite & & & & & & & $\begin{array}{c}0.122 \\
(2.27)^{* *}\end{array}$ & $\begin{array}{c}0.214 \\
(2.00)^{* *}\end{array}$ \\
\hline Tenure & & & & & $\begin{array}{c}-0.106 \\
(-3.28)^{* * *}\end{array}$ & $\begin{array}{c}-0.166 \\
(-3.25)^{* * *}\end{array}$ & $\begin{array}{c}-0.106 \\
(-3.28)^{* * *}\end{array}$ & $\begin{array}{c}-0.166 \\
(-3.25)^{* * *}\end{array}$ \\
\hline TenHet & & & & & $\begin{array}{c}-0.123 \\
(-2.21)^{* *}\end{array}$ & $\begin{array}{c}-0.205 \\
(-2.05)^{* *}\end{array}$ & $\begin{array}{c}-0.123 \\
(-2.21)^{* *}\end{array}$ & $\begin{array}{c}-0.205 \\
(-2.05)^{* *}\end{array}$ \\
\hline LnAssets & $\begin{array}{c}-0.162 \\
(-6.96)^{* * *}\end{array}$ & $\begin{array}{c}-0.231 \\
(-5.66)^{* * *}\end{array}$ & $\begin{array}{c}-0.160 \\
(-7.11)^{* * *}\end{array}$ & $\begin{array}{c}-0.227 \\
(-5.75)^{* * *}\end{array}$ & $\begin{array}{c}-0.122 \\
(-6.55)^{* * *}\end{array}$ & $\begin{array}{c}-0.201 \\
(-6.09)^{* * *}\end{array}$ & $\begin{array}{c}-0.121 \\
(-6.55)^{* * *}\end{array}$ & $\begin{array}{c}-0.201 \\
(-6.08)^{* * *}\end{array}$ \\
\hline OutDir & $\begin{array}{c}0.693 \\
(6.65)^{* * *}\end{array}$ & $\begin{array}{c}1.017 \\
(5.92)^{* * *}\end{array}$ & $\begin{array}{c}0.682 \\
(6.40)^{* * *}\end{array}$ & $\begin{array}{c}0.997 \\
(5.67)^{* * *}\end{array}$ & $\begin{array}{c}0.370 \\
(2.98)^{* * *}\end{array}$ & $\begin{array}{c}0.530 \\
(2.71)^{* * *}\end{array}$ & $\begin{array}{c}0.370 \\
(2.98)^{* * *}\end{array}$ & $\begin{array}{c}0.530 \\
(2.71)^{* * * *}\end{array}$ \\
\hline InsideOwn & $\begin{array}{l}0.007 \\
(0.08)\end{array}$ & $\begin{array}{l}0.023 \\
(0.17)\end{array}$ & $\begin{array}{l}0.008 \\
(0.10)\end{array}$ & $\begin{array}{l}0.029 \\
(0.21)\end{array}$ & $\begin{array}{l}0.088 \\
(1.24)\end{array}$ & $\begin{array}{l}0.168 \\
(1.22)\end{array}$ & $\begin{array}{l}0.088 \\
(1.24)\end{array}$ & $\begin{array}{l}0.168 \\
(1.22)\end{array}$ \\
\hline $\mathrm{CEO} /$ Chair & $\begin{array}{l}0.077 \\
(1.41)\end{array}$ & $\begin{array}{l}0.078 \\
(0.94)\end{array}$ & $\begin{array}{l}0.080 \\
(1.51)\end{array}$ & $\begin{array}{l}0.081 \\
(1.00)\end{array}$ & $\begin{array}{c}0.122 \\
(2.25)^{* *}\end{array}$ & $\begin{array}{c}0.164 \\
(1.87)^{*}\end{array}$ & $\begin{array}{c}0.122 \\
(2.25)^{* *}\end{array}$ & $\begin{array}{c}0.164 \\
(1.87)^{*}\end{array}$ \\
\hline CapEx/Assets -1 & $\begin{array}{l}-0.245 \\
(-0.55)\end{array}$ & $\begin{array}{l}-0.154 \\
(-0.22)\end{array}$ & $\begin{array}{l}-0.245 \\
(-0.55)\end{array}$ & $\begin{array}{l}-0.155 \\
(-0.23)\end{array}$ & $\begin{array}{c}-0.914 \\
(-1.72)^{*}\end{array}$ & $\begin{array}{l}-1.416 \\
(-1.57)\end{array}$ & $\begin{array}{c}-0.914 \\
(-1.72)^{*}\end{array}$ & $\begin{array}{l}-1.416 \\
(-1.57)\end{array}$ \\
\hline $\begin{array}{l}\text { NI/Sales -1 } \\
\text { Industry Dummies }\end{array}$ & $\begin{array}{c}-0.001 \\
(-4.50)^{* * *} \\
\text { Yes }\end{array}$ & $\begin{array}{c}-0.001 \\
(-3.82)^{* * * *} \\
\text { Yes }\end{array}$ & $\begin{array}{c}-0.001 \\
(-4.58)^{* * * *} \\
\text { Yes }\end{array}$ & $\begin{array}{c}-0.001 \\
(-3.93)^{* * * *} \\
\text { Yes }\end{array}$ & $\begin{array}{c}-0.001 \\
(-5.36)^{* * *} \\
\text { Yes }\end{array}$ & $\begin{array}{c}-0.001 \\
(-4.34)^{* * *} \\
\text { Yes }\end{array}$ & $\begin{array}{c}-0.001 \\
(-5.35)^{* * * *} \\
\text { Yes }\end{array}$ & $\begin{array}{c}-0.001 \\
(-4.33)^{* * *} \\
\text { Yes }\end{array}$ \\
\hline $\mathrm{N}$ & 1.706 & 1,706 & 1,706 & 1,706 & 1,706 & 1.706 & 1,706 & 1.706 \\
\hline
\end{tabular}


Table 11. Relationship between pre-IPO innovation, management quality, and the changes in post-IPO operating performance

The sample consists of 1,851 venture-backed IPOs conducted between 1993 and 2004. OIBDA is the ratio of operating income before depreciation plus interest income (Compustat items 13 and 62, respectively) to the book value of total assets (item 6). $\triangle$ OIBDA is the change in OIBDA calculated as the difference in the OIBDA in a given year after the IPO (up to five years including the year of IPO) and the OIBDA in the fiscal year prior to IPO (year -1). Year 0 is the year of IPO. LnAssets is the natural logarithm of the book value of assets immediately prior to IPO. LnAge is the natural logarithm of one plus firm age. OutDir is the proportion of outside directors in the board of directors. InsideOwn is the proportion of voting power owned by firm officers and directors immediately prior to IPO. $\mathrm{CEO} / \mathrm{Chair}$ is an indicator variable equal to one if a CEO is also a Chairman of the board of directors, and zero otherwise. CapEx/Assets -1 is the ratio of capital expenditures over assets in fiscal year -1 prior to IPO. NI/Sales -1 is the ratio of net income to sales in fiscal year -1 prior to IPO. All regressions include 4-digit SIC industry code dummies and year dummies. All specifications are estimated using quantile/median regressions. $t$-statistics are in parentheses. ${ }^{* *},{ }^{* *}$, and ${ }^{*}$ indicate significance at the 1,5 , and 10 percent levels, respectively.

Panel A. Relationship between pre-IPO innovation and the changes in post-IPO operating performance

LnCount $-1 \&-2$ is the natural logarithm of one plus the number of patents a firm files for (and is eventually granted) in years -1 and -2 combined prior to IPO. LnCite $-1 \&-2$ is the natural logarithm of one plus the number of non-self-citations per patent a firm files for (and is eventually granted) in years -1 and -2 combined prior to IPO.

\begin{tabular}{|c|c|c|c|c|c|c|c|c|c|c|c|c|}
\hline & $(1)$ & (2) & (3) & (4) & (5) & (6) & (7) & (8) & (9) & (10) & (11) & $(12)$ \\
\hline Dependent variable & $\triangle \mathrm{OIBDA}$ & $\triangle \mathrm{OIBDA}$ & $\triangle \mathrm{OIBDA}$ & $\triangle \mathrm{OIBDA}$ & $\triangle \mathrm{OIBDA}$ & $\triangle \mathrm{OIBDA}$ & $\triangle \mathrm{OIBDA}$ & $\triangle \mathrm{OIBDA}$ & $\triangle \mathrm{OIBDA}$ & $\triangle \mathrm{OIBDA}$ & $\triangle \mathrm{OIBDA}$ & $\triangle \mathrm{OIBDA}$ \\
\hline & -1 to 0 & -1 to 1 & -1 to 2 & -1 to 3 & -1 to 4 & -1 to 5 & -1 to 0 & -1 to 1 & -1 to 2 & -1 to 3 & -1 to 4 & -1 to 5 \\
\hline Constant & 0.735 & 0.090 & 0.533 & 1.591 & 1.632 & 1.229 & 0.726 & 0.058 & 0.508 & 0.825 & 0.881 & 1.113 \\
\hline & $(1.75)^{*}$ & $(0.21)$ & $(1.11)$ & $(3.41)^{* * *}$ & $(3.06)^{* * *}$ & $(2.26)^{* *}$ & $(1.76)^{*}$ & $(0.13)$ & $(1.09)$ & $(1.76)^{*}$ & $(1.63)$ & $(2.07)^{* *}$ \\
\hline LnCount $-1 \&-2$ & 0.034 & 0.031 & 0.046 & 0.021 & 0.005 & 0.048 & & & & & & \\
\hline & $(2.05)^{* *}$ & $(1.71)^{*}$ & $(2.31)^{* *}$ & $(1.05)$ & $(0.22)$ & $(1.94)^{*}$ & & & & & & \\
\hline LnCite $-1 \&$-2 & & & & & & & $\begin{array}{c}0.033 \\
(3.61)^{* * *}\end{array}$ & $\begin{array}{c}0.027 \\
(2.61)^{* * *}\end{array}$ & $\begin{array}{c}0.041 \\
(3.73)^{* * *}\end{array}$ & $\begin{array}{c}0.035 \\
(2.95)^{* * *}\end{array}$ & $\begin{array}{c}0.028 \\
(2.05)^{* *}\end{array}$ & $\begin{array}{c}0.042 \\
(3.00)^{* * *}\end{array}$ \\
\hline LnAssets & $\begin{array}{c}-0.034 \\
(-4.11)^{* * *}\end{array}$ & $\begin{array}{c}-0.018 \\
(-1.95)^{*}\end{array}$ & $\begin{array}{l}-0.012 \\
(-1.15)\end{array}$ & $\begin{array}{l}-0.017 \\
(-1.60)\end{array}$ & $\begin{array}{c}-0.025 \\
(-1.89)^{*}\end{array}$ & $\begin{array}{c}-0.027 \\
(-2.00)^{* *}\end{array}$ & $\begin{array}{c}-0.032 \\
(-3.90)^{* * *}\end{array}$ & $\begin{array}{c}-0.017 \\
(-1.80)^{*}\end{array}$ & $\begin{array}{l}-0.012 \\
(-1.20)\end{array}$ & $\begin{array}{l}-0.015 \\
(-1.35)\end{array}$ & $\begin{array}{c}-0.026 \\
(-1.98)^{* *}\end{array}$ & $\begin{array}{c}-0.025 \\
(-1.86)^{*}\end{array}$ \\
\hline LnAge & $\begin{array}{c}-0.035 \\
(-2.42)^{* *}\end{array}$ & $\begin{array}{c}-0.031 \\
(-1.94)^{*}\end{array}$ & $\begin{array}{c}-0.066 \\
(-3.54)^{* * *}\end{array}$ & $\begin{array}{c}-0.065 \\
(-3.34)^{* * *}\end{array}$ & $\begin{array}{c}-0.061 \\
(-2.60) * * *\end{array}$ & $\begin{array}{c}-0.123 \\
(-5.06)^{* * *}\end{array}$ & $\begin{array}{c}-0.034 \\
(-2.37)^{* *}\end{array}$ & $\begin{array}{c}-0.027 \\
(-1.65)^{*}\end{array}$ & $\begin{array}{c}-0.063 \\
(-3.49)^{* * *}\end{array}$ & $\begin{array}{c}-0.067 \\
(-3.36)^{* * *}\end{array}$ & $\begin{array}{c}-0.067 \\
(-2.90)^{* * *}\end{array}$ & $\begin{array}{c}-0.107 \\
(-4.46)^{* * *}\end{array}$ \\
\hline OutDir & $\begin{array}{l}0.077 \\
(1.45)\end{array}$ & $\begin{array}{c}0.170 \\
(2.94)^{* * *}\end{array}$ & $\begin{array}{l}0.098 \\
(1.49)\end{array}$ & $\begin{array}{c}0.127 \\
(1.85)^{*}\end{array}$ & $\begin{array}{l}0.106 \\
(1.30)\end{array}$ & $\begin{array}{c}0.102 \\
(1.18)\end{array}$ & $\begin{array}{l}0.073 \\
(1.40)\end{array}$ & $\begin{array}{c}0.170 \\
(2.85)^{* * *}\end{array}$ & $\begin{array}{l}0.099 \\
(1.55)\end{array}$ & $\begin{array}{c}0.123 \\
(1.75)^{*}\end{array}$ & $\begin{array}{l}0.103 \\
(1.29)\end{array}$ & $\begin{array}{l}0.050 \\
(0.59)\end{array}$ \\
\hline InsideOwn & $\begin{array}{c}-0.089 \\
(-2.52)^{* *}\end{array}$ & $\begin{array}{l}-0.055 \\
(-1.40)\end{array}$ & $\begin{array}{l}-0.073 \\
(-1.64)\end{array}$ & $\begin{array}{c}-0.084 \\
(-1.80)^{*}\end{array}$ & $\begin{array}{c}-0.106 \\
(-1.91)^{*}\end{array}$ & $\begin{array}{c}-0.131 \\
(-2.26)^{* *}\end{array}$ & $\begin{array}{c}-0.096 \\
(-2.75)^{* * *}\end{array}$ & $\begin{array}{l}-0.044 \\
(-1.09)\end{array}$ & $\begin{array}{l}-0.067 \\
(-1.54)\end{array}$ & $\begin{array}{c}-0.092 \\
(-1.94)^{*}\end{array}$ & $\begin{array}{l}-0.090 \\
(-1.65)\end{array}$ & $\begin{array}{c}-0.122 \\
(-2.13)^{* *}\end{array}$ \\
\hline CEO/Chair & $\begin{array}{l}0.008 \\
(0.43)\end{array}$ & $\begin{array}{l}-0.007 \\
(-0.34)\end{array}$ & $\begin{array}{l}0.012 \\
(0.52)\end{array}$ & $\begin{array}{l}0.004 \\
(0.19)\end{array}$ & $\begin{array}{l}0.020 \\
(0.69)\end{array}$ & $\begin{array}{l}0.031 \\
(1.05)\end{array}$ & $\begin{array}{l}0.007 \\
(0.38)\end{array}$ & $\begin{array}{l}-0.003 \\
(-0.13)\end{array}$ & $\begin{array}{l}0.011 \\
(0.49)\end{array}$ & $\begin{array}{l}0.018 \\
(0.74)\end{array}$ & $\begin{array}{l}0.032 \\
(1.15)\end{array}$ & $\begin{array}{l}0.043 \\
(1.50)\end{array}$ \\
\hline CapEx/Assets -1 & $\begin{array}{c}0.240 \\
(2.67)^{* * *}\end{array}$ & $\begin{array}{c}0.394 \\
(3.98)^{* * *}\end{array}$ & $\begin{array}{c}0.333 \\
(2.82)^{* * *}\end{array}$ & $\begin{array}{c}0.338 \\
(2.66)^{* * *}\end{array}$ & $\begin{array}{l}0.226 \\
(1.50)\end{array}$ & $\begin{array}{l}0.084 \\
(0.56)\end{array}$ & $\begin{array}{c}0.198 \\
(2.23)^{* *}\end{array}$ & $\begin{array}{c}0.422 \\
(4.13)^{* * *}\end{array}$ & $\begin{array}{c}0.332 \\
(2.89)^{* * *}\end{array}$ & $\begin{array}{c}0.331 \\
(2.55)^{* *}\end{array}$ & $\begin{array}{l}0.178 \\
(1.20)\end{array}$ & $\begin{array}{l}0.142 \\
(0.97)\end{array}$ \\
\hline NI/Sales -1 & $\begin{array}{c}-0.001 \\
(-6.21)^{* * *}\end{array}$ & $\begin{array}{c}-0.001 \\
(-5.57)^{* * *}\end{array}$ & $\begin{array}{c}-0.000 \\
(-1.90)^{*}\end{array}$ & $\begin{array}{c}-0.001 \\
(-3.45)^{* * *}\end{array}$ & $\begin{array}{c}-0.001 \\
(-4.26)^{* * *}\end{array}$ & $\begin{array}{c}-0.001 \\
(-3.26)^{* * *}\end{array}$ & $\begin{array}{c}-0.001 \\
(-6.36)^{* * *}\end{array}$ & $\begin{array}{c}-0.001 \\
(-5.38)^{* * *}\end{array}$ & $\begin{array}{c}-0.000 \\
(-1.98)^{* *}\end{array}$ & $\begin{array}{c}-0.001 \\
(-3.57)^{* * *}\end{array}$ & $\begin{array}{c}-0.001 \\
(-4.33)^{* * *}\end{array}$ & $\begin{array}{c}-0.001 \\
(-3.37)^{* * *}\end{array}$ \\
\hline Industry Dummies & Yes & Yes & Yes & Yes & Yes & Yes & Yes & Yes & Yes & Yes & Yes & Yes \\
\hline Year Dummies & Yes & Yes & Yes & Yes & Yes & Yes & Yes & Yes & Yes & Yes & Yes & Yes \\
\hline $\mathrm{N}$ & 1,670 & 1,536 & 1,372 & 1,218 & 1,088 & 893 & 1,670 & 1,536 & 1,372 & 1,218 & 1,088 & 893 \\
\hline Pseudo $\mathrm{R}^{2}$ & 0.1329 & 0.1166 & 0.1290 & 0.1720 & 0.1829 & 0.2286 & 0.1346 & 0.1178 & 0.1330 & 0.1740 & 0.1847 & 0.2318 \\
\hline
\end{tabular}


Table 11 (continued)

Panel B. Relationship between pre-IPO innovation, management quality, and the changes in post-IPO operating performance

Q1Count is a dummy variable which takes a value of one for firms with above median number of patents a firm files for (and is eventually granted) in years -1 and -2 combined prior to IPO and above median MQFactor, and zero otherwise. Q1Cite is a dummy variable which takes a value of one for firms with above median number of non-self-citations per patent a firm files for (and is eventually granted) in years -1 and -2 combined prior to IPO and above median MQFactor, and zero otherwise. MQFactor is the management quality factor score obtained using common factor analysis on the firm-size-, firmage-, and industry-dummies-adjusted TSize, MBA, PriorExp, LawAcc, CPA, Core, CEODom, and Board. Tenure is the average number of years a firm's management team members have been with the firm. TenHet is the coefficient of variation of management team members' tenures.

\begin{tabular}{|c|c|c|c|c|c|c|c|c|c|c|c|c|}
\hline & $(1)$ & (2) & (3) & (4) & (5) & (6) & (7) & $(8)$ & (9) & $(10)$ & (11) & $(12)$ \\
\hline Dependent variable & $\begin{array}{c}\Delta \text { OIBDA } \\
-1 \text { to } 0\end{array}$ & $\begin{array}{c}\Delta \text { OIBDA } \\
-1 \text { to } 1\end{array}$ & $\begin{array}{c}\Delta \text { OIBDA } \\
-1 \text { to } 2\end{array}$ & $\begin{array}{c}\Delta \text { OIBDA } \\
-1 \text { to } 3\end{array}$ & $\begin{array}{c}\Delta \text { OIBDA } \\
-1 \text { to } 4\end{array}$ & $\begin{array}{c}\Delta \text { OIBDA } \\
-1 \text { to } 5\end{array}$ & $\begin{array}{c}\Delta \text { OIBDA } \\
-1 \text { to } 0\end{array}$ & $\begin{array}{c}\Delta \text { OIBDA } \\
-1 \text { to } 1\end{array}$ & $\begin{array}{c}\Delta \text { OIBDA } \\
-1 \text { to } 2\end{array}$ & $\begin{array}{c}\Delta \text { OIBDA } \\
-1 \text { to } 3\end{array}$ & $\begin{array}{c}\triangle \text { OIBDA } \\
-1 \text { to } 4\end{array}$ & $\begin{array}{c}\Delta \text { OIBDA } \\
-1 \text { to } 5\end{array}$ \\
\hline Constant & $\begin{array}{c}0.696 \\
(1.63)\end{array}$ & $\begin{array}{l}0.652 \\
(1.39)\end{array}$ & $\begin{array}{l}0.601 \\
(1.24)\end{array}$ & $\begin{array}{l}0.844 \\
(1.59)\end{array}$ & $\begin{array}{c}0.763 \\
(1.36)\end{array}$ & $\begin{array}{c}1.139 \\
(2.07)^{* *}\end{array}$ & $\begin{array}{c}0.808 \\
(1.95)^{*}\end{array}$ & $\begin{array}{c}0.663 \\
(1.41)\end{array}$ & $\begin{array}{l}0.602 \\
(1.24)\end{array}$ & $\begin{array}{c}0.845 \\
(1.57)\end{array}$ & $\begin{array}{c}0.773 \\
(1.39)\end{array}$ & $\begin{array}{c}1.139 \\
(2.07)^{* *}\end{array}$ \\
\hline Q1Count & $\begin{array}{c}0.142 \\
(4.43)^{* * *}\end{array}$ & $\begin{array}{c}0.112 \\
(3.15)^{* * *}\end{array}$ & $\begin{array}{c}0.147 \\
(3.83)^{* * *}\end{array}$ & $\begin{array}{c}0.118 \\
(2.70)^{* * *}\end{array}$ & $\begin{array}{c}0.094 \\
(2.01)^{* *}\end{array}$ & $\begin{array}{c}0.111 \\
(2.39)^{* *}\end{array}$ & & & & & & \\
\hline Q1Cite & & & & & & & $\begin{array}{c}0.144 \\
(4.56)^{* * *}\end{array}$ & $\begin{array}{c}0.119 \\
(3.31)^{* * *}\end{array}$ & $\begin{array}{c}0.149 \\
(3.88)^{* * *}\end{array}$ & $\begin{array}{c}0.126 \\
(2.85)^{* * *}\end{array}$ & $\begin{array}{c}0.093 \\
(1.98)^{* *}\end{array}$ & $\begin{array}{c}0.111 \\
(2.39)^{* *}\end{array}$ \\
\hline Tenure & $\begin{array}{l}-0.004 \\
(-1.09)\end{array}$ & $\begin{array}{l}-0.004 \\
(-0.88)\end{array}$ & $\begin{array}{l}-0.005 \\
(-1.06)\end{array}$ & $\begin{array}{l}-0.006 \\
(-1.18)\end{array}$ & $\begin{array}{l}-0.005 \\
(-0.91)\end{array}$ & $\begin{array}{c}-0.014 \\
(-2.03)^{* *}\end{array}$ & $\begin{array}{l}-0.004 \\
(-1.14)\end{array}$ & $\begin{array}{l}-0.004 \\
(-0.84)\end{array}$ & $\begin{array}{l}-0.005 \\
(-1.05)\end{array}$ & $\begin{array}{l}-0.006 \\
(-1.19)\end{array}$ & $\begin{array}{l}-0.006 \\
(-0.95)\end{array}$ & $\begin{array}{c}-0.014 \\
(-2.03)^{* *}\end{array}$ \\
\hline TenHet & $\begin{array}{l}-0.002 \\
(-0.14)\end{array}$ & $\begin{array}{l}-0.016 \\
(-1.26)\end{array}$ & $\begin{array}{l}-0.015 \\
(-1.04)\end{array}$ & $\begin{array}{l}-0.006 \\
(-0.38)\end{array}$ & $\begin{array}{l}-0.011 \\
(-0.67)\end{array}$ & $\begin{array}{l}-0.004 \\
(-0.29)\end{array}$ & $\begin{array}{l}-0.002 \\
(-0.14)\end{array}$ & $\begin{array}{l}-0.017 \\
(-1.32)\end{array}$ & $\begin{array}{l}-0.015 \\
(-1.06)\end{array}$ & $\begin{array}{l}-0.007 \\
(-0.48)\end{array}$ & $\begin{array}{l}-0.010 \\
(-0.65)\end{array}$ & $\begin{array}{l}-0.004 \\
(-0.29)\end{array}$ \\
\hline LnAssets & $\begin{array}{c}-0.030 \\
(-3.71)^{* * *}\end{array}$ & $\begin{array}{c}-0.021 \\
(-2.26)^{* *}\end{array}$ & $\begin{array}{l}-0.015 \\
(-1.45)\end{array}$ & $\begin{array}{c}-0.024 \\
(-2.02)^{* *}\end{array}$ & $\begin{array}{c}-0.026 \\
(-1.98)^{* *}\end{array}$ & $\begin{array}{c}-0.025 \\
(-1.85)^{*}\end{array}$ & $\begin{array}{c}-0.031 \\
(-3.82)^{* * *}\end{array}$ & $\begin{array}{c}-0.021 \\
(-2.29)^{* *}\end{array}$ & $\begin{array}{l}-0.015 \\
(-1.46)\end{array}$ & $\begin{array}{c}-0.023 \\
(-1.97)^{* *}\end{array}$ & $\begin{array}{c}-0.026 \\
(-2.00)^{* *}\end{array}$ & $\begin{array}{c}-0.025 \\
(-1.85)^{*}\end{array}$ \\
\hline LnAge & $\begin{array}{l}-0.024 \\
(-1.45)\end{array}$ & $\begin{array}{l}-0.019 \\
(-0.96)\end{array}$ & $\begin{array}{c}-0.045 \\
(-2.11)^{* *}\end{array}$ & $\begin{array}{c}-0.050 \\
(-2.05)^{* *}\end{array}$ & $\begin{array}{c}-0.050 \\
(-1.80)^{*}\end{array}$ & $\begin{array}{c}-0.074 \\
(-2.53)^{* *}\end{array}$ & $\begin{array}{l}-0.023 \\
(-1.40)\end{array}$ & $\begin{array}{l}-0.017 \\
(-0.91)\end{array}$ & $\begin{array}{c}-0.045 \\
(-2.13)^{* *}\end{array}$ & $\begin{array}{c}-0.049 \\
(-2.00)^{* *}\end{array}$ & $\begin{array}{c}-0.050 \\
(-1.82)^{*}\end{array}$ & $\begin{array}{c}-0.074 \\
(-2.53)^{* *}\end{array}$ \\
\hline OutDir & $\begin{array}{l}0.077 \\
(1.45)\end{array}$ & $\begin{array}{c}0.162 \\
(2.71)^{* * *}\end{array}$ & $\begin{array}{l}0.093 \\
(1.42)\end{array}$ & $\begin{array}{c}0.127 \\
(1.70)^{*}\end{array}$ & $\begin{array}{l}0.105 \\
(1.29)\end{array}$ & $\begin{array}{l}0.026 \\
(0.30)\end{array}$ & $\begin{array}{l}0.072 \\
(1.39)\end{array}$ & $\begin{array}{c}0.157 \\
(2.62)^{* * *}\end{array}$ & $\begin{array}{l}0.092 \\
(1.42)\end{array}$ & $\begin{array}{c}0.125 \\
(1.67)^{*}\end{array}$ & $\begin{array}{l}0.103 \\
(1.27)\end{array}$ & $\begin{array}{l}0.026 \\
(0.30)\end{array}$ \\
\hline InsideOwn & $\begin{array}{c}-0.101 \\
(-2.87)^{* * *}\end{array}$ & $\begin{array}{l}-0.049 \\
(-1.21)\end{array}$ & $\begin{array}{l}-0.067 \\
(-1.51)\end{array}$ & $\begin{array}{c}-0.092 \\
(-1.82)^{*}\end{array}$ & $\begin{array}{l}-0.088 \\
(-1.59)\end{array}$ & $\begin{array}{c}-0.128 \\
(-2.27)^{* *}\end{array}$ & $\begin{array}{c}-0.104 \\
(-3.01)^{* * *}\end{array}$ & $\begin{array}{l}-0.047 \\
(-1.16)\end{array}$ & $\begin{array}{l}-0.068 \\
(-1.53)\end{array}$ & $\begin{array}{c}-0.090 \\
(-1.78)^{*}\end{array}$ & $\begin{array}{l}-0.086 \\
(-1.57)\end{array}$ & $\begin{array}{c}-0.128 \\
(-2.27)^{* *}\end{array}$ \\
\hline CEO/Chair & $\begin{array}{l}0.003 \\
(0.18)\end{array}$ & $\begin{array}{l}-0.006 \\
(-0.29)\end{array}$ & $\begin{array}{l}0.018 \\
(0.83)\end{array}$ & $\begin{array}{l}0.009 \\
(0.34)\end{array}$ & $\begin{array}{l}0.023 \\
(0.83)\end{array}$ & $\begin{array}{l}0.036 \\
(1.25)\end{array}$ & $\begin{array}{l}0.002 \\
(0.14)\end{array}$ & $\begin{array}{l}-0.005 \\
(-0.23)\end{array}$ & $\begin{array}{l}0.019 \\
(0.84)\end{array}$ & $\begin{array}{l}0.010 \\
(0.39)\end{array}$ & $\begin{array}{l}0.022 \\
(0.77)\end{array}$ & $\begin{array}{l}0.036 \\
(1.25)\end{array}$ \\
\hline CapEx/Assets -1 & $\begin{array}{c}0.253 \\
(2.84)^{* * *}\end{array}$ & $\begin{array}{c}0.419 \\
(4.12)^{* * *}\end{array}$ & $\begin{array}{c}0.318 \\
(2.72)^{* * *}\end{array}$ & $\begin{array}{c}0.255 \\
(1.86)^{*}\end{array}$ & $\begin{array}{l}0.167 \\
(1.12)\end{array}$ & $\begin{array}{l}0.129 \\
(0.90)\end{array}$ & $\begin{array}{c}0.269 \\
(3.08)^{* * *}\end{array}$ & $\begin{array}{c}0.418 \\
(4.10)^{* * *}\end{array}$ & $\begin{array}{c}0.319 \\
(2.74)^{* * *}\end{array}$ & $\begin{array}{c}0.274 \\
(1.98)^{* *}\end{array}$ & $\begin{array}{l}0.174 \\
(1.18)\end{array}$ & $\begin{array}{l}0.129 \\
(0.90)\end{array}$ \\
\hline NI/Sales -1 & $\begin{array}{c}-0.001 \\
(-6.46)^{* * *}\end{array}$ & $\begin{array}{c}-0.001 \\
(-4.10)^{* * *}\end{array}$ & $\begin{array}{c}-0.000 \\
(-1.95)^{*}\end{array}$ & $\begin{array}{c}-0.001 \\
(-3.38)^{* * *}\end{array}$ & $\begin{array}{c}-0.001 \\
(-3.08)^{* * *}\end{array}$ & $\begin{array}{c}-0.001 \\
(-3.20)^{* * *}\end{array}$ & $\begin{array}{c}-0.001 \\
(-6.57)^{* * *}\end{array}$ & $\begin{array}{c}-0.001 \\
(-5.38)^{* * *}\end{array}$ & $\begin{array}{c}-0.000 \\
(-1.95)^{*}\end{array}$ & $\begin{array}{c}-0.001 \\
(-3.34)^{* * *}\end{array}$ & $\begin{array}{c}-0.001 \\
(-2.94)^{* * *}\end{array}$ & $\begin{array}{c}-0.001 \\
(-3.20)^{* * *}\end{array}$ \\
\hline $\begin{array}{l}\text { Industry Dummies } \\
\text { Year Dummies }\end{array}$ & $\begin{array}{l}\text { Yes } \\
\text { Yes } \\
\end{array}$ & $\begin{array}{l}\text { Yes } \\
\text { Yes }\end{array}$ & $\begin{array}{l}\text { Yes } \\
\text { Yes } \\
\end{array}$ & $\begin{array}{l}\text { Yes } \\
\text { Yes } \\
\end{array}$ & $\begin{array}{l}\text { Yes } \\
\text { Yes }\end{array}$ & $\begin{array}{l}\text { Yes } \\
\text { Yes }\end{array}$ & $\begin{array}{l}\text { Yes } \\
\text { Yes }\end{array}$ & $\begin{array}{l}\text { Yes } \\
\text { Yes }\end{array}$ & $\begin{array}{l}\text { Yes } \\
\text { Yes } \\
\end{array}$ & $\begin{array}{l}\text { Yes } \\
\text { Yes } \\
\end{array}$ & $\begin{array}{l}\text { Yes } \\
\text { Yes }\end{array}$ & $\begin{array}{l}\text { Yes } \\
\text { Yes } \\
\end{array}$ \\
\hline $\mathrm{N}$ & 1,670 & 1,536 & 1,372 & 1,218 & 1,088 & 893 & 1,670 & 1,536 & 1,372 & 1,218 & 1,088 & 893 \\
\hline Pseudo $\mathrm{R}^{2}$ & 0.1383 & 0.1208 & 0.1331 & 0.1754 & 0.1854 & 0.2336 & 0.1385 & 0.1210 & 0.1334 & 0.1757 & 0.1852 & 0.2336 \\
\hline
\end{tabular}

